\title{
Archaeological Investigations of Rainwater Catchment Basins along the South Wall of Mission San Jose, San Antonio, Texas
}

Steve A. Tomka

Raba Kistner

Anne A. Fox

Center for Archaeological Research

Follow this and additional works at: https://scholarworks.sfasu.edu/ita

Part of the American Material Culture Commons, Archaeological Anthropology Commons, Environmental Studies Commons, Other American Studies Commons, Other Arts and Humanities Commons, Other History of Art, Architecture, and Archaeology Commons, and the United States History Commons

Tell us how this article helped you.

This Article is brought to you for free and open access by the Center for Regional Heritage Research at SFA ScholarWorks. It has been accepted for inclusion in Index of Texas Archaeology: Open Access Gray Literature from the Lone Star State by an authorized editor of SFA ScholarWorks. For more information, please contact cdsscholarworks@sfasu.edu. 


\section{Archaeological Investigations of Rainwater Catchment Basins along the South Wall of Mission San Jose, San Antonio, Texas}

\section{Creative Commons License}

\section{(c) (1) (8)}

This work is licensed under a Creative Commons Attribution-NonCommercial 4.0 International License 


\section{Archaeological Investigations of Rainwater Catchment Basins along the South Wall of Mission San José, San Antonio, Texas}

Steve A. Tomka and Anne A. Fox

with a contribution by Barbara A. Meissner

Robert J. Hard and C. Britt Bousman Principal Investigators

Texas Antiquities Permit No. 1945

Ccopyright 1999

Center for Archaeological Research

The University of Texas at San Antonio

Archaeological Survey Report, No. 287 
The following information is provided in accordance with the General Rules of Practice and Procedure, Chapter 41.11 (Investigative Reports), Texas Antiquities Committee:

1. Type of investigation: Mitigation

2. Project name: San José Catchment Basins

3. County: Bexar

4. Principal investigator: Robert J. Hard and C. Britt Bousman

5. Name and location of sponsoring agency: San Antonio Missions National Historical Park, National Park Service, San Antonio, Texas

6. Texas Antiquities Permit No.: 1945

7. Published by the Center for Archaeological Research, The University of Texas at San Antonio, 6900 N. Loop 1604 W., San Antonio, Texas 78249-0658, 1999

A list of publications offered by the Center for Archaeological Research is available. Call (210) 458-4378; write to the Center for Archaeological Research, The University of Texas at San Antonio, 6900 N. Loop 1604 W., San Antonio, Texas 78249-0658; e-mail to car@lonestar.utsa.edu; or visit CAR's web site at http://www.csbs.utsa.edu/research/car/index.htm. 


\begin{abstract}
In February and early March 1998, the Center for Archaeological Research of The University of Texas at San Antonio, conducted excavations outside the south wall and in the general vicinity of the southeast gate of Mission San José y San Miguel de Aguayo (41BX3) for the San Antonio Missions National Historical Park of the National Park Service (NPS). The site is located ca. seven miles south of downtown San Antonio on a high terrace overlooking the west bank of the San Antonio River.

The general purpose of the excavations was to determine the nature and content of the subsurface deposits in advance of the excavation of three drainage basins and connecting drain pipes under the three eastern-most canales adjacent the southeast gate. Specifically, the excavations had three goals: 1) identify any architectural features that may have originally been outside of the mission walls; 2) better define the stratigraphy of the cultural materials in the area; and 3) recover intact colonial period materials that might otherwise be lost.

The excavations showed that: 1) large quantities of bones are present along the 102-ft-long portion of the wall; 2) much of the cultural material-bearing matrix found above the sterile Houston Black Clay has been stripped away along the planned route of the main drainage line; and 3) a thick caliche layer located in the westernmost catch basin may cap deeper deposits containing primarily Goliad wares. In addition, the excavations revealed two features, a historic period brazier and two intersecting hearths.
\end{abstract}

We recommend that all work associated with the construction of the three catch basins and connecting pipes proceed as planned. 


\section{Contents}

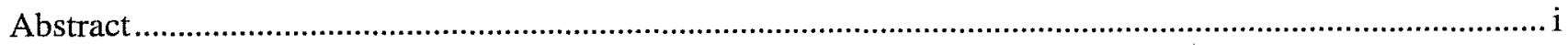

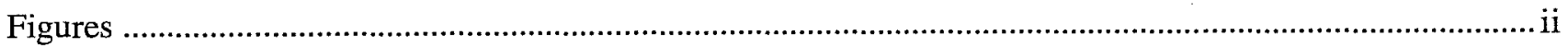

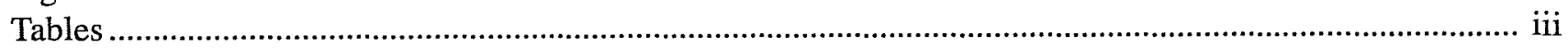

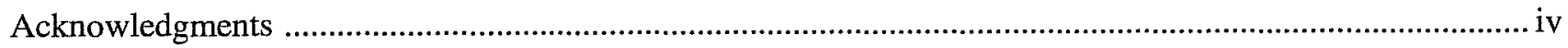

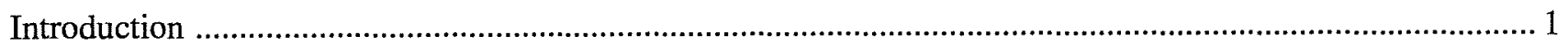

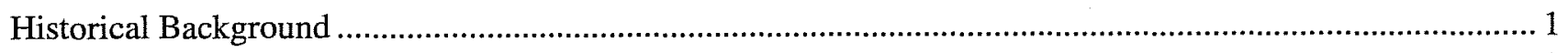

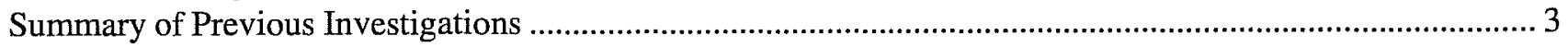

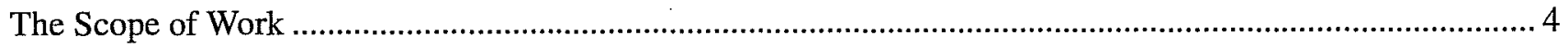

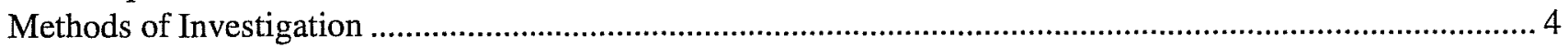

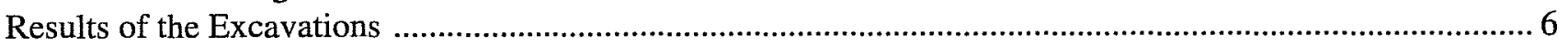

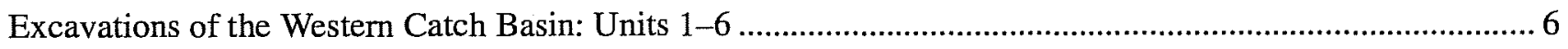

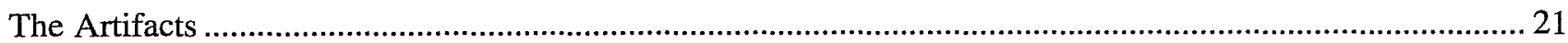

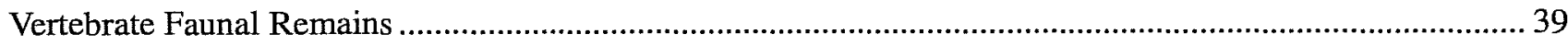

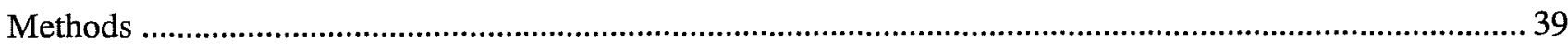

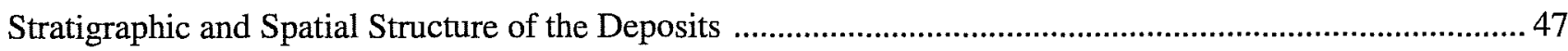

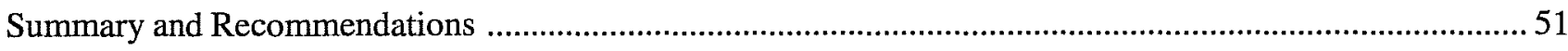

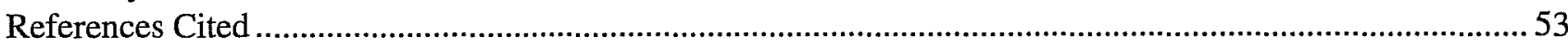

\section{Figures}

1. Location of Mission San José within the San Antonio Missions National Historical Park ......................... 1

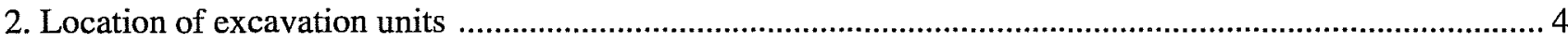

3. Profile of the west wall of the western catch basin .......................................................................... 7

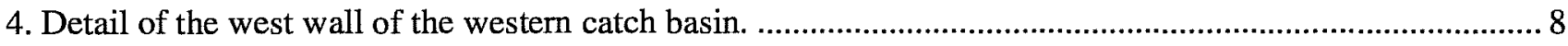

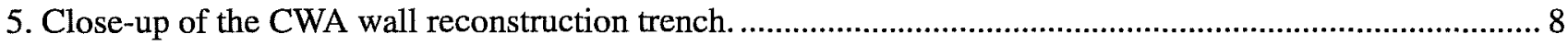

6. East wall profile of the western catch basin. ....................................................................................... 10

7. Detail of the east wall of the western catch basin ....................................................................... 11

8. Top of the bone layer in Units 2 and 4, western catch basin. .......................................................... 12

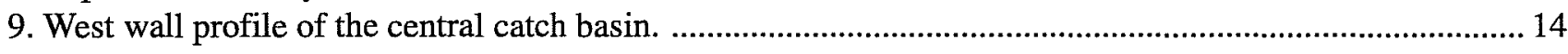

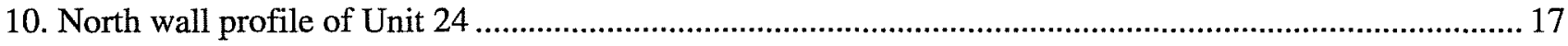

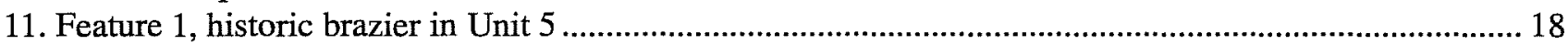

12. Feature 2, intersecting historic hearths in Units 10 and 28 , central catch basin .................................. 19

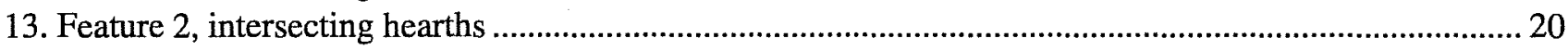

14. Machine-made medicine bottle near the bottom of the hearth in Feature 2, Unit 28 .............................20

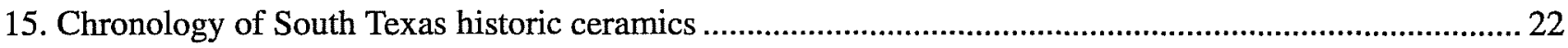

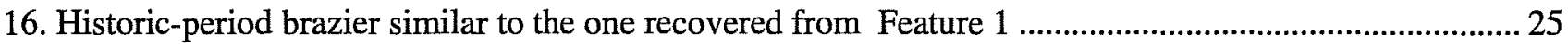

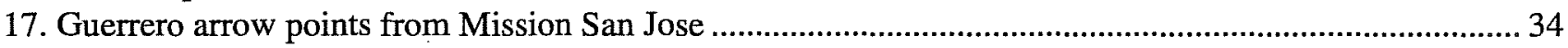

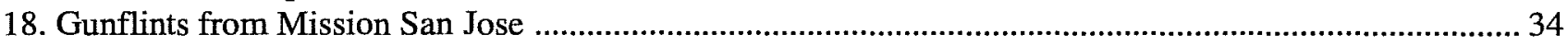

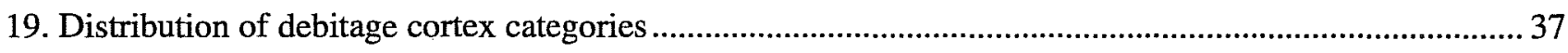

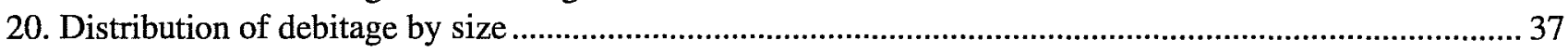

21. Distribution of platform-bearing flakes by facet count …................................................................ 37

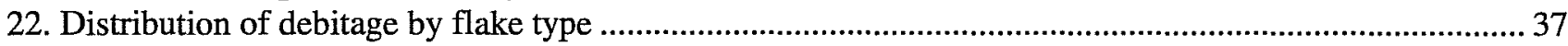

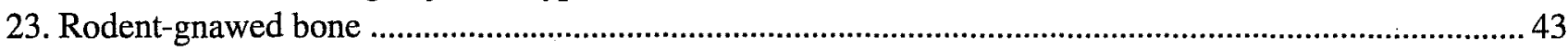

24. Bone with numerous cut marks, posterior view .......................................................................... 44

25. The relationship between arbitrary and natural strata and bone layer, Units 2,4 , and $1 \ldots \ldots \ldots \ldots \ldots \ldots \ldots . . . . . . . . . .50$ 


\section{Tables}

1. Artifacts Recovered from Western Catch Basin Excavation Units ......................................................... 6

2. Artifacts Recovered by Arbitrary Level from Units 1, 3, 5, and 6, West Basin ......................................... 9

3. Artifacts Recovered by Natural Stratigraphy from Units 2 and 4, West Basin ......................................... 11

4. Artifacts Recovered from Central Catch Basin Excavation Units ........................................................... 13

5. Artifacts Recovered by Arbitrary Level from the Central Basin, Units 7, 9-12, and 28 ........................... 15

6. Artifacts Recovered from Excavation Units in Pipe Trenches, Units 13-27 ............................................. 16

7. Artifacts Recovered from Excavation Units in Pipe Trenches, Units 1-3 ............................................... 17

8. Artifacts Recovered from All Excavation Units ................................................................................. 23

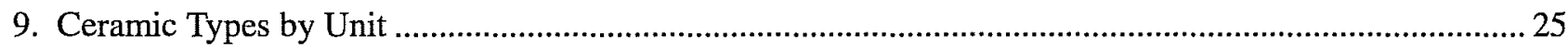

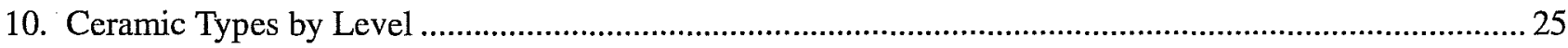

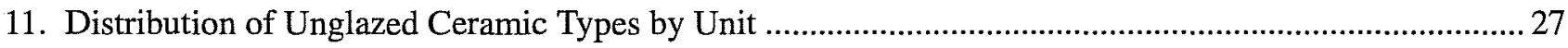

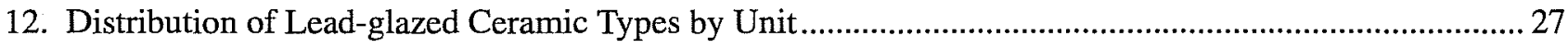

13. Distribution of Tin-glazed Ceramic Types by Unit ………............................................................... 28

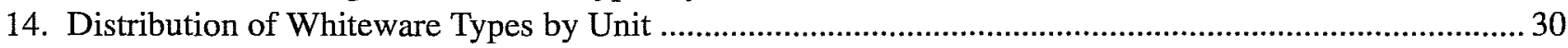

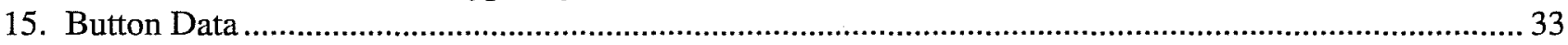

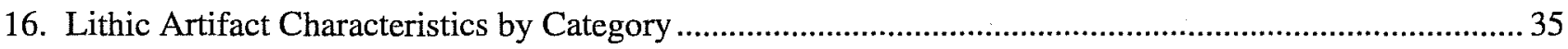

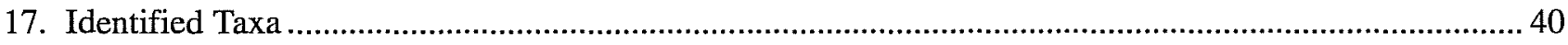

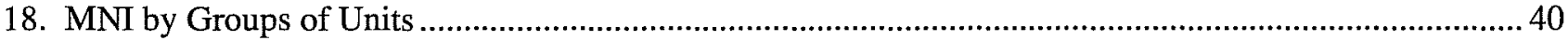

19. Bone Identified to the Genus Taxonomic Level, with NISP, Counts, and Percentages .............................. 43

20. Percent of Total NISP Bone Weight for Selected Taxa ........................................................................... 42

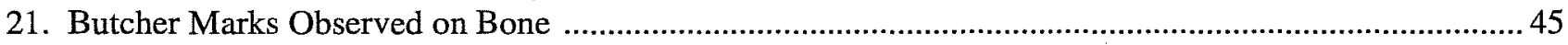

22. Comparison of Bone Counts, Weights, and NISP in Six Recent Colonial Site Excavations ...................... 44

23. Break Types on Long Bones of Cow-sized Mammals ........................................................................... 46

24. Distribution of Ceramic Types by Arbitrary Level Within the Western Catch Basin,

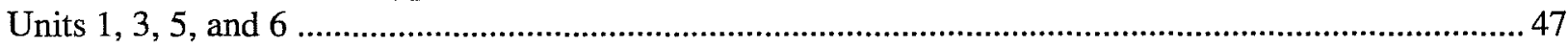

25. Distribution of Ceramic Types by Level Within the Central Catch Basin ................................................ 47

26. Distribution of Ceramic Types by Natural Level Within the Western Catch Basin, Units 2 and 4

27. Distribution of Ceramic Types by Natural Level Within the Connecting and Main Pipe

Trenches, Units 13-27 48

28. Vertical Distribution of Faunal Remains Within the Western and

Central Catch Basins and the Pipe Trenches 


\section{Acknowledgments}

The successful completion of this project is owed in large part to the able and hard working field crew and lab technicians that helped in excavating and processing the large quantity of materials obtained during the test excavations. They include the following individuals: Donna Edmondson, Jeff Francis, Kevin Hanselka, Chris Horrell, Richard Jones, Kimberly Kvernes, Anthony Lyle, Barbara Meissner, Clemente Murguia, Gloria Murguia, Ruth Mathews, Preston McWhorter, and Debora Weksler. San Antonio Missions National Historical Park Superintendent Stephen E. Whitesell; Assistant Superintendent Mary A. Bomar; and Mark Chavez, chief, Division of Professional Services, facilitated the project in many ways. We gratefully acknowledge the support of the CAR staff, in particular Robert J. Hard, director; C. Britt Bousman, associate director; Brett A. Houk, small

projects manager, and Marcie Renner, technical editor. The figures were drafted by Bruce Moses and Chris Butler. 


\section{Introduction}

\section{Steve A. Tomka}

Pursuant to a contract between the National Park Service (NPS) and the Center for Archaeological Research (CAR) of The University of Texas at San Antonio (UTSA), CAR personnel undertook excavations along the south wall of Mission San José y San Miguel de Aguayo during February and March 1998. The purpose of the excavations was to: 1) identify any architectural features that may have originally been outside of the mission walls; 2) better define the stratigraphy of the cultural materials in the area; and 3) recover intact colonial period materials that might otherwise be lost. The excavations were to take place preceding the construction of catch basins under the first three canales located immediately west of the Southeast gate of the mission.

Mission San José y San Miguel de Aguayo is a designated State Archaeological Landmark (SAL). It is one of four local missions under the auspices of NPS within San Antonio Missions National Historical Park (Figure 1) and bears the state archaeological site trinomial number 41BX3.

The excavations were carried out in compliance with Section 106 of the National Historic Preservation Act of 1966 (as amended), under Texas Antiquities Permit No. 1945. The field work was accomplished in a combined total of 15 work days by a crew ranging from four to 12 individuals. Serving as principal and co-principal investigators were Robert J. Hard and C. Britt Bousman, respectively. The project archaeologist was Steve A. Tomka. The CAR staff and field crew consisted of Donna Edmondson, Jeff Francis, Chris Horrell, Richard Jones, Kimberly Kvernes, Anthony Lyle, Preston McWhorter, Barbara Meissner, Gloria Murguia, Clemente Murguia, and Ruth Mathews.

\section{Historical Background}

\author{
Anne A. Fox
}

Mission San José y San Miguel de Aguayo was founded in February 1720 on the east bank of the San Antonio River (Figure 1) about 3.5 miles south of

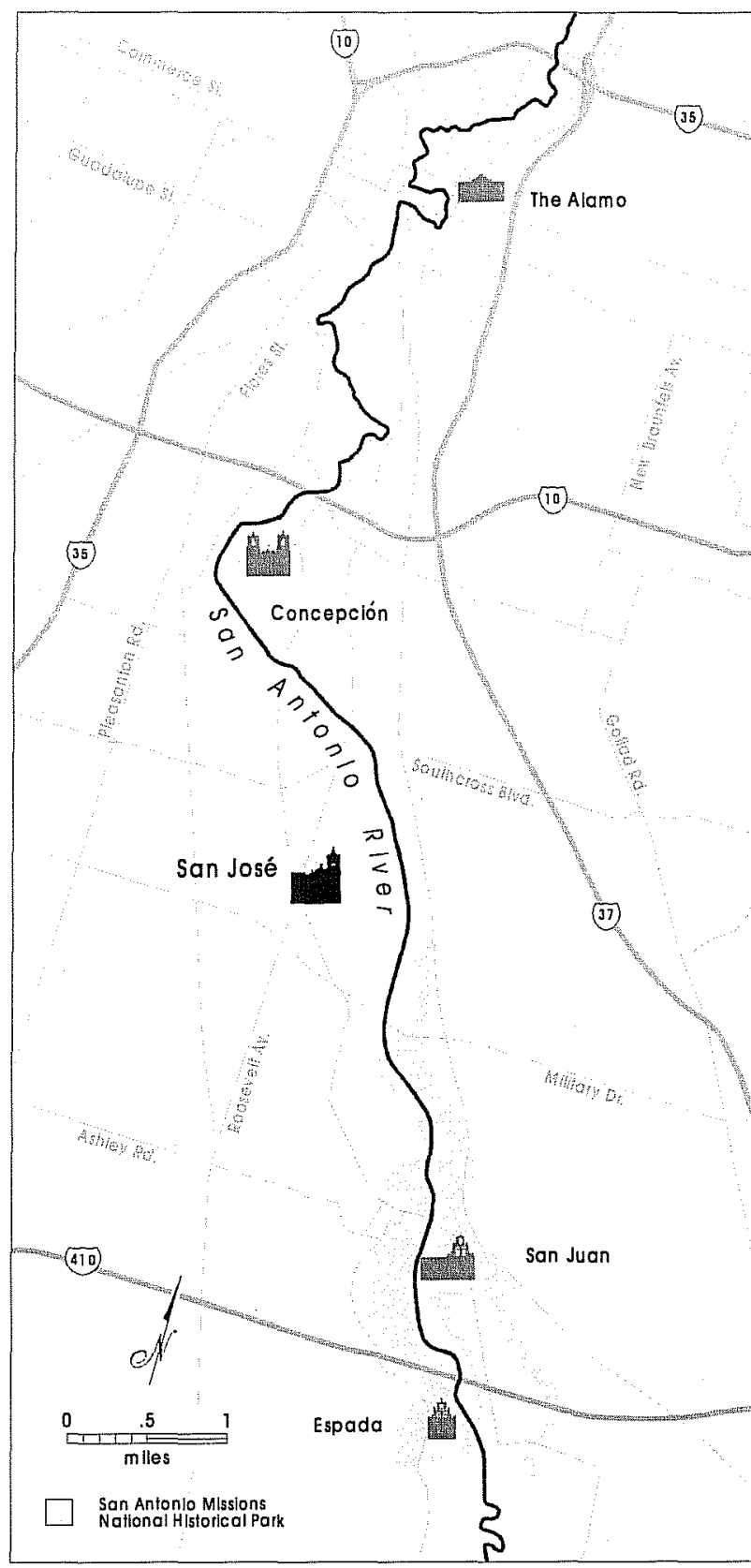

Figure 1. Location of Mission San José within the San Antonio Missions National Historical Park (shaded area). 
Mission San Antonio de Valero (the Alamo). By the following spring, 227 Indians resided there (Habig 1968a:86). The mission was relocated across the river to its present site sometime between 1724 and 1727 . Constructed during the following 70 years were a granary, a friary, stone Indian houses, and a stone church (Habig 1978). By 1789 the mission was enclosed by a wall with four bastions and six gates.

The Indian population began to decline in the last quarter of the eighteenth century, and by 1791, only 106 Indians remained in residence (Habig 1968a:103). Secularization of the mission began in 1794 when the property was divided among the 93 remaining Indians. During the nineteenth century, the population consisted of local families who had taken up residence in and around the mission. A gradual decline in use and a lack of interest on the part of San Antonians allowed deterioration of the mission buildings. Vandalism and weathering of unprotected architecture occurred until 1868 when the north wall of the church collapsed, causing the later collapse of the dome as well (Habig 1968b:148). The spiral staircase for the church tower fell in 1903. Although the staircase was restored in 1920 , the tower itself partially collapsed in 1928 .

After Bexar County obtained title to the various plots of land in the vicinity to create a park, in 1933 the Civil Works Administration began the reconstruction of the original south, west, and east walls of the mission, which had been the Indian Quarters. On May 8,1941 , the entire site had been acquired by the State of Texas in cooperation with the Archdiocese of San Antonio, and San José was designated a National Historic Site during a formal dedication (Habig 1968b:185-186). At another ceremony on February 20, 1983, Mission San José and three other San Antonio missions were combined into the San Antonio Missions National Historical Park.

No documentary descriptions have so far been found that indicate the method of construction or the exact location of the Indian Quarters during the first years of San José's existence on its present site. However, it was customary for the first, temporary buildings on a Spanish colonial site to be of jacal construction, a method which involved setting upright logs into trenches to form walls, over which a thatched roof was constructed.

By 1749, Father Ciprián reported that at least some of the Indian houses were made of stone (Habig 1968a:49). Of 84 Indian apartments in 1755, 12 were of stone and consisted of two rooms each. They were arranged in "street-like form" (Leutenegger et al. 1978:115). This layout resembles those described for the earliest years at missions San Juan Capistrano (Schuetz 1968:33) and San Antonio de Valero (Fox et al. 1976:3). Governor Barrios in 1758 described the Indian Quarters as consisting of eight units or squares of stone with flat roofs and parapets arranged within a larger square (Habig 1968a:50-51). By the time of the visit of Father Gaspar de Solís in 1768, the Indian apartments were stone structures formed as a part of the perimeter walls (Habig 1968a:55). This description was confirmed by Father Juan Agustín Morfi in 1777 (Habig 1968a:68).

After the secularization of the mission in 1794 and the division of the property, the houses of the Indian Quarters that were unoccupied began to deteriorate into ruins. Some were replaced by frame houses as the mid-nineteenth century approached. By the early twentieth century, the mission was the center of a small settlement composed primarily of the descendants of the first landowners (Hard et al. 1995:3-8). A 1905 USGS map and an aerial photograph taken 15 years later indicate small structures stood along the south, west, and east sides of the compound at that time, most of them of frame construction. A few traces of the original walls still existed as ruins.

By the time of the CWA reconstruction of the mission walls in 1933, the only trace of the original Indian Quarters visible above the ground was a small section of one apartment at the southwest corner, visible on aerial photographs but probably hardly noticeable from ground level (Hard et al. 1995:Figure 5). The foundations of the original walls were relocated by the CWA workers under the instructions of architect Harvey Smith and the new walls were then built upon these foundations. This has since been confirmed by various archaeological excavations and by Fox's observations of small construction projects on the site since 1971. 


\section{Summary of Previous Investigations}

\section{Anne A. Fox}

A number of archaeological investigations have been carried out at Mission San José in the past 30 years. Although only one of them has involved excavation of the Indian Quarters, each investigation has added a bit more to our knowledge of the architecture and the artifactual deposits present on the site.

In 1968, Mardith Schuetz (1970) of the Witte Museum monitored and recovered artifacts from a series of sprinkler system trenches throughout the mission. The trenches averaged 12 inches in depth. The trenches and their laterals extended throughout the interior of the compound as well as outside and parallel to the south, west, and north walls. Several buried foundations were encountered within the mission. Few field notes were taken, and the report consists mostly of lists of artifacts recovered from each trench and a few brief descriptions of features encountered.

In 1970, Daniel Fox (1970) reported several monitoring operations previously carried out as well as testing he conducted in the vicinity of the north wall of the mission. Included in this report are descriptions of monitoring of a large sewer line trench dug in December 1969 parallel to and north of the north wall of the mission, and an electrical line trench dug just north of the church in April 1970. The third section of the report deals with the excavation in August 1970 of a 2.5-x-3-m test pit north of the church where a persimmon tree was to be planted. Also mentioned is a drainage trench $30 \mathrm{~cm}$ wide and $40 \mathrm{~cm}$ deep dug by workmen for a pipe to carry water from the church entrance patio to a drain east of the north wall rooms.

In 1974, John Clark (1978) of Texas Historical Commission (THC) conducted test excavations in a number of locations around the mission buildings to study the effects of climatic conditions on the major structures. This involved the excavation of eight test units, generally $1 \times 2 \mathrm{~m}$, in $20 \mathrm{~cm}$ levels. Clark also included much useful information of the history and construction of the various buildings at the mission and a detailed plan showing all disturbances that had occurred and archaeological units that had been excavated at the mission up to that time.

In 1979, John Clark and Elton Prewitt conducted a testing operation to the west of the granary in preparation for the proposed installation of a French drain that was "intended to relieve moisture-related structural problems along the west wall of the granary" (Clark and Prewitt 1979:iii). Six 0.5-x-1-m test pits were excavated in the area to be affected. These revealed a remnant of a flagstone surface and a number of pits and other disturbances. Artifactual evidence of Spanish colonial and later uses of the area eventually caused a reconsideration of the original plan to install the drain.

When improvements were planned to Napier Avenue in 1984, the Texas State Department of Highways and Public Transportation conducted investigations in the roadbed, locating a number of features (Henderson and Clark 1984). Among these were a section of an acequia lateral southeast of the mission compound, a nineteenth-century burial dug into the west bank of that feature, and what appeared to be a Colonial foundation trench ca. $100 \mathrm{ft}$ outside the south wall of the mission. The latter contained a number of post holes, suggesting that it represented a corral structure. Colonial and later period artifacts were recovered.

In 1991, CAR conducted archival research and backhoe testing to locate and map the acequia outside the east wall of the mission in preparation for the construction of a parking area for a new visitor's center (Fox and Cox 1991). The exact location of the acequia madre or main ditch was determined by the excavation of two backhoe trenches perpendicular to the suspected path of the acequia and following out the line of the feature based on early maps of the area. The ditch was found to contain late-nineteenth- and earlytwentieth-century fill. An acequia lateral first located by Henderson and Clark (1984) was relocated and mapped by crossing it periodically with backhoe cuts (Fox and Cox 1991:Figure 3). This investigation resulted in the recommendation that subsurface preparation for the parking lot avoid excavating deeper than one foot below the ground surface. 
CAR conducted test excavations at the southeast gateway and throughout the interior compound of the mission in 1993 (Hard et al. 1995) and additional excavations at the gateway in 1996 (Tennis 1998). These investigations included excavation units within the gateway which revealed the construction of the nineteenth-century road that ran through the area and the original location of the mission walls. The testing within the compound yielded information on the nature and depth of mission period and later deposits, making it possible to plan needed changes in the drainage patterns within the compound.

The previous excavations that have been most pertinent to the present project were conducted by CAR archaeologists in the vicinity of the southeast gate of the mission during the summer and fall of 1997 (Tomka and Fox 1998). Part of this project included excavation of three 3-x-3-ft units under the first drain immediately adjacent the southeast gate and an additional unit some 10 feet w est. A second project during the fall of the same year in:tvolved the excavation of a number of shovel tests alor $g$ the outside walls of the mission. Two of these were located in the vicinity of the three catch basins (Tomkc and Fox 1998). These excavations revealed the rela ionship between the reconstruction wall base and th : colonial foundation, and established the presence $o$ cultural materials as much as $50 \mathrm{ft}$ outside of the sou h wall of the mission.

\section{The Scope of Work}

\section{Steve A. Tomka}

Given the need to install three drainage basins under the first three canales adjacent the southeast gate, the goals of the field work at Mission San José y San Miguel de Aguayo (41BX3) consisted of the following: 1) identify any architectural features that may have originally been outside of the mission walls; 2) better define the stratigraphy of the cultural materials in the area; and 3) recover intact colonial period materials that might otherwise be lost. Because previous archaeological work by CAR (Tomka and Fox 1998) immediately under the easternmost canal excavated a large portion of the catch basin, no further work was to be carried out in this location. The archaeological work was to concentrate on excavations associated with the western-most and central catch basins and the connecting and main trenches draining the three basins (Figure 2).

\section{Methods of Investigation}

The number, location, and approximate size of the test units were all specified by the Scope of Work provided by the NPS. Six 3-x-3-ft units were excavated in the westernmost basin (Units 1-6; Figure 2). Six 3-x-3-ft

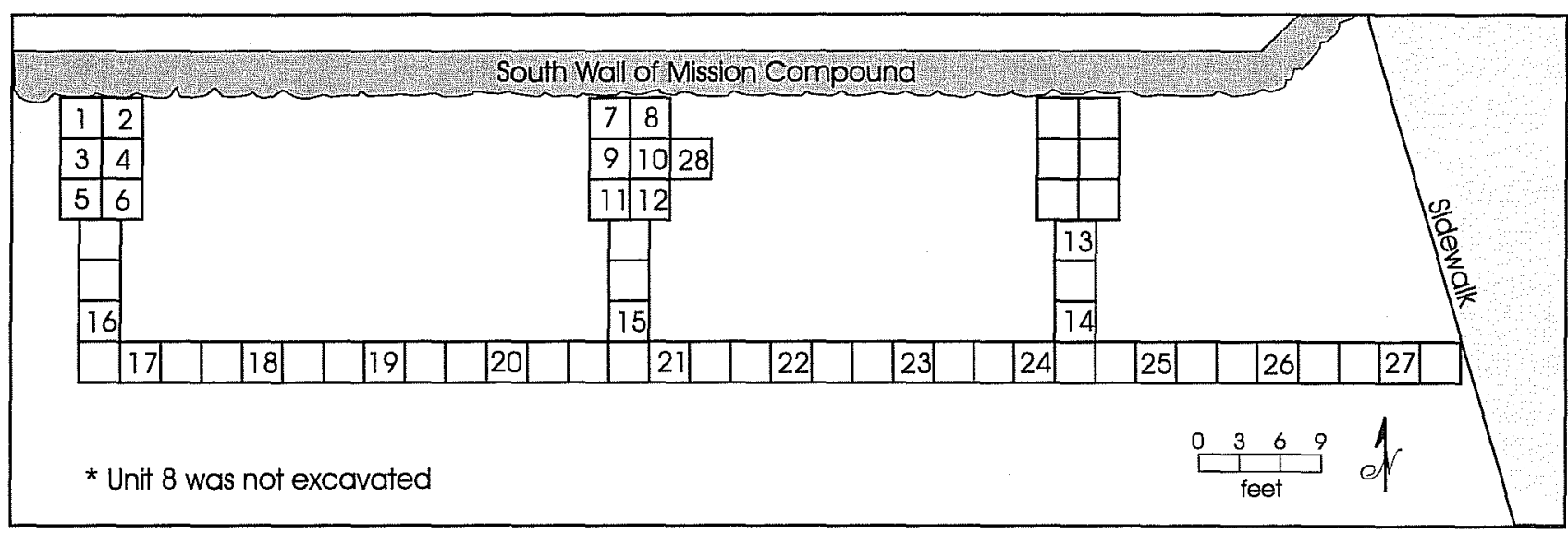

Figure 2. Location of excavation units. 
units also were to be excavated within the central catch basin. However, because a feature was uncovered in Unit 10 extending into the eastern profile, the adjacent unit (Unit 28) was excavated to fully uncover the feature. Since, with the excavation of Unit 28 the six units allotted for this catch basin were used up, it was decided to forgo the excavation of Unit 8 located immediately against the mission wall. It was felt that since the area adjacent the wall base was heavily impacted by WCA reconstruction activities, the materials would have been heavily disturbed and little would have been learned from them regarding stratigraphy adjacent the wall. One unit each was excavated in the westernmost and central trenches connecting the basins to the main drainage pipe (Units 16 and 15 , respectively). In addition, two units were excavated in the trench connecting the easternmost basin with the main drainage pipe (Units 13 and 14). Finally, eleven units were excavated along the main drainage pipe trench (Units 17-27). No excavation was required in the planned location of the easternmost catch basin-nearest the southeast gate-since most of the area was excavated during the August/ September 1997 field work.

To correspond to the drawings in the 1976 report by Roberson and Medlin, measurements were done in inches and feet during the field work. With the exception of two units ( 2 and 4 ), the deposits in all other units were excavated in six-inch levels. To more carefully investigate the stratigraphy of the deposits Units 2 and 4 were excavated using the natural stratigraphy evident in the area. At least one selected wall of each unit was profiled and photographed. To document the changes in the thickness of deposits as one moves away from the south wall of the mission, two long (21-ft) profiles were also drawn connecting the two catch basins with units dug in the main connecting pipe trench.

Prior to the beginning of the excavations the upper six inches of top soil in each of the two catch basins and along all pipe trenches was excavated by crews provided by Greystone, Inc. All remaining deposits were excavated by CAR personnel. All soil removed during these excavations was screened through $1 / 4$-inch mesh. The soil from inside the intersecting hearths (Feature 2) in Units 10 and 28 was bagged and returned to CAR for screening through $1 / 8$-inch mesh. Artifacts recovered from all levels were bagged and returned to the laboratory. Level records were kept on standard CAR forms and a day-to-day narrative of the work was kept by the project archaeologist.

In the laboratory, the artifacts were washed and cataloged on standard historic artifact forms used by CAR. The main artifact categories employed in classifying the collection consisted of: ceramics; household (i.e., glass containers, tablewares, and kitchenwares); personal items (i.e., clothing, jewelry, amusements, and personal objects); barn/workshop/ garage; arms; construction (i.e., nails, other hardware, building materials); metal (i.e., objects, indet. frags.); lithics; and faunal remains. Analysis of the artifacts included identification and approximate dating of the ceramics and glass, identification of arrow point types and functional and morphological lithic tool categories, and identification of the faunal material. All field photographs, artifacts, and records are curated at CAR. 


\section{Results of the Excavations}

\section{Steve A. Tomka and Anne A. Fox}

\section{Excavations of the Western Catch Basin: Units 1-6}

All units were excavated to a depth of 30 inches below surface. Units $1,3,5$, and 6 were excavated in sixinch levels. Units 2 and 4 were dug following the natural stratigraphy evident in the east wall profiles of Units 1 and 3, respectively. The shift to natural stratigraphy occurred because of two reasons: 1) a caliche layer, only present in the eastern half of Units 1,3 , and 5 capped deposits that appeared to contain primarily colonial materials; and 2) to define whether an 8-10-inch-thick layer of bone, that ran from about 16-20 inches below surface (bs) across much of the catch basin, represented a single depositional unit or potentially two lenses separated by a thin layer or sterile soil.

An east-west running sprinkler pipe marked the boundary between Units 3 and 4 on the north and 5 and 6 on its south sides. The pipe is located 72 inches south of the mission wall and it is found at a depth of 6.5 inches belwo datum (bd) (Figure 2).
The artifacts recovered from the six units are listed in Table 1. Faunal remains, primarily cow bones, dominate the artifacts recovered (see Faunal Analysis). Ceramics are the second most common artifact category, while metal objects and fragments, construction materials, and household items are present in moderate quantities. Chipped lithic artifacts occur in small numbers while other artifact categories are infrequent.

\section{Units Excavated in Arbitrary Levels (Units 1, 3, 5, and 6)}

The stratigraphy of the units excavated in arbitrary levels along the western half of this catch basin (Units 1,3 , and 5) consisted of 2-5 inches of loose, light brown to gray sandy matrix that represents modern topsoil probably introduced as landscape fill (Figures 3 and 4). A 6-8 inch thick disturbed layer is found below the top soil in Units 3 and 5. It has a lighter color than the overlying topsoil and contains numerous caliche pebbles. It is thickest at its northern end and thins to 1-2 inches by the time it reaches Units 16 and 17 , at a distance of 15-21 ft from the south wall of the mission. The trench dug to hold the sprinkler pipe found between Units 3 and 5 crosscuts the layer

Table 1. Artifacts Recovered from Western Catch Basin Excavation Units

\begin{tabular}{|c|c|c|c|c|c|c|c|c|c|c|}
\hline Unit & 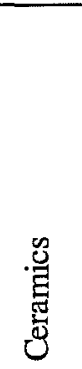 & $\begin{array}{l}\text { 믕 } \\
\frac{0}{0} \\
0 \\
0 \\
0\end{array}$ & 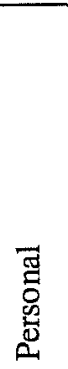 & 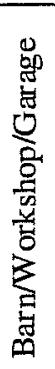 & 萣 & 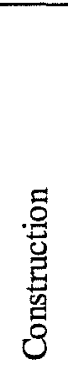 & $\sum_{\sum}^{\frac{\pi}{0}}$ & 兽 & ஜ̊ & Total \\
\hline 1 & 91 & 59 & & & & 59 & 54 & 9 & 1092 & 1364 \\
\hline 2 & 206 & 23 & 2 & & 1 & 41 & 38 & 10 & 1870 & 2191 \\
\hline 3 & 62 & 53 & 6 & & & 32 & 68 & 13 & 1292 & 1526 \\
\hline 4 & 220 & 42 & & 2 & & 21 & 20 & 15 & 1621 & 1941 \\
\hline 5 & 100 & 35 & 1 & & & 69 & 173 & 8 & 940 & 1326 \\
\hline 6 & 82 & 18 & & 1 & & 15 & 2 & 7 & 564 & 689 \\
\hline Total & 761 & 230 & 9 & 3 & 1 & 237 & 355 & 62 & 7379 & 9037 \\
\hline
\end{tabular}




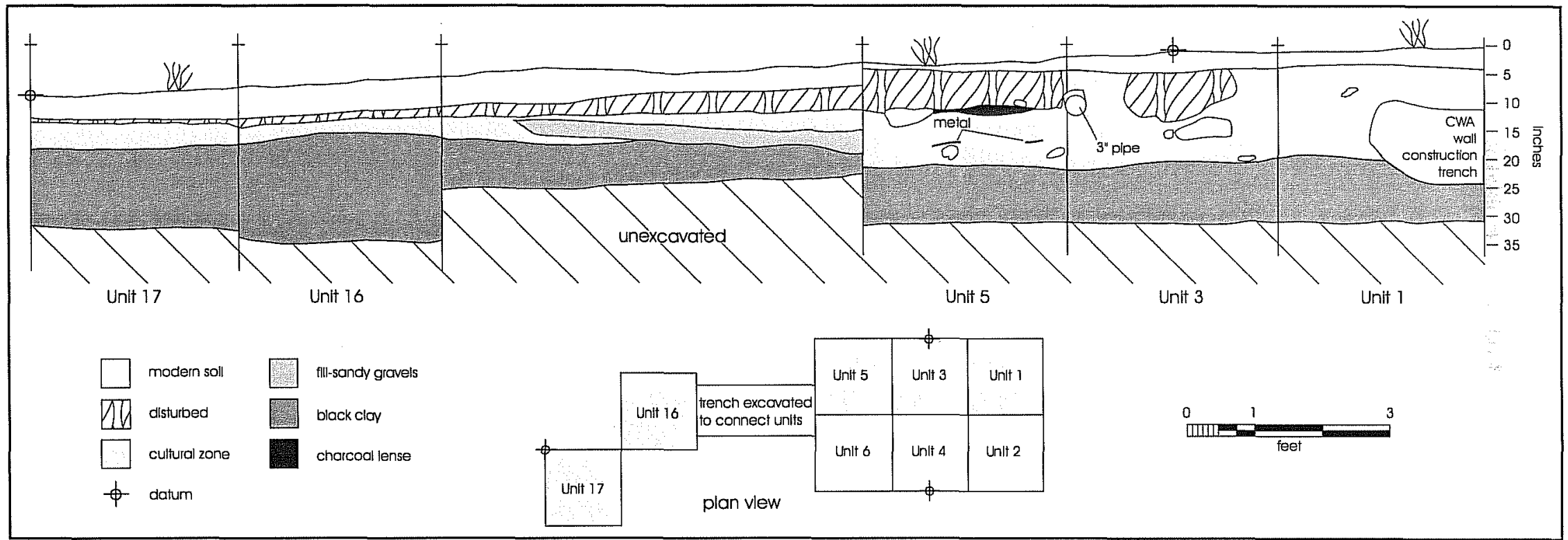

Figure 3. Profile of the west wall of the western catch basin. 


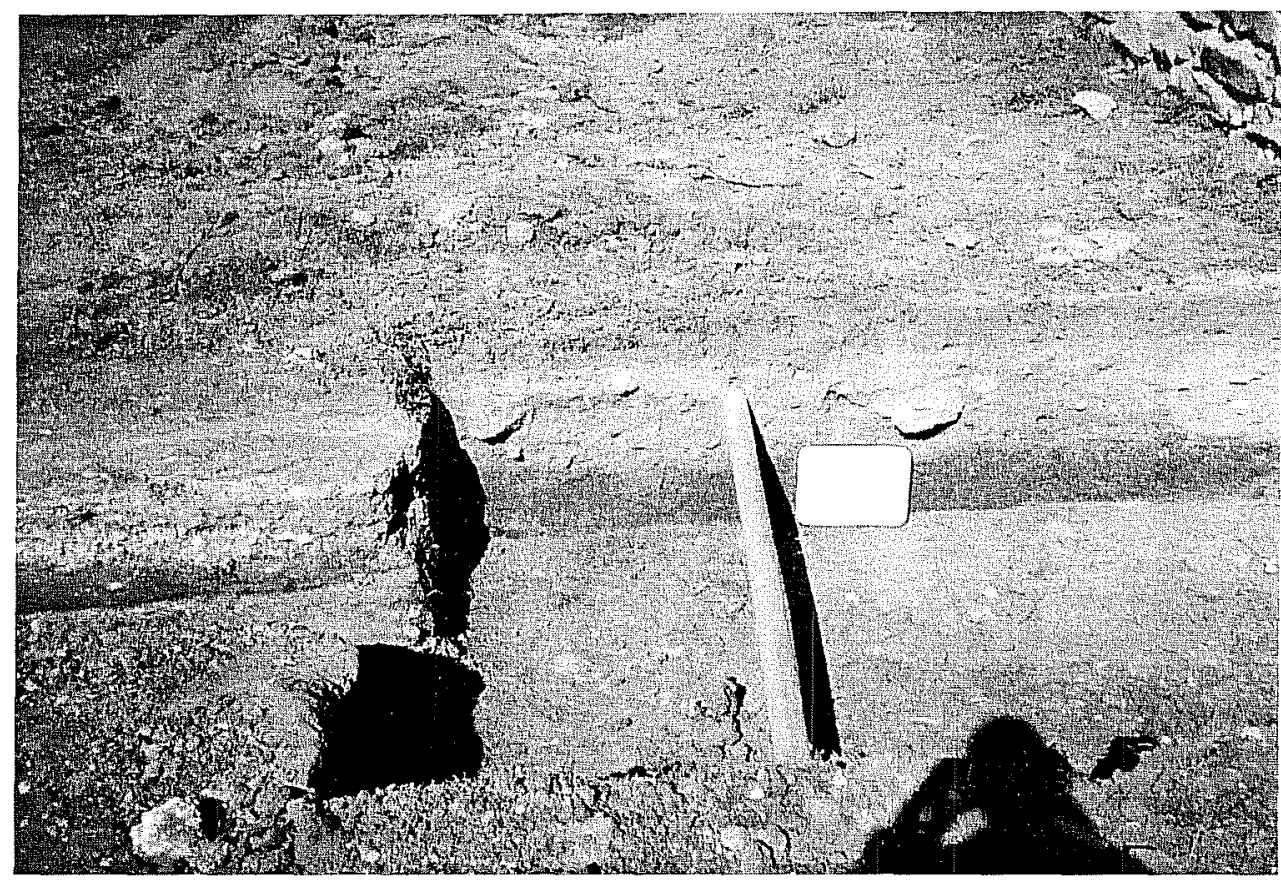

suggesting that it predates 1965 , the year the sprinkler system was installed. Below the top soil in Unit 1 and below the disturbed layer in Units 3,5,16, and 17 is a thick grayish brown zone that extends to the dark brown to black clay substrate underlying the earliest occupation of the mission. The zone ranges from 14 to 15 inches in thickness in Units 1,3 , and 5 and contains the bulk of the material remains recovered. In Unit 1 this zone is cut through by the CWA reconstruction trench (Figure 5). The outline of the trench has a slightly concave base and a somewhat rounded end opposite the reconstruction wall base. It extends 20 inches from the wall and it meets the wall at the top of the colonial foundation at a depth of 22 inches bs. The top portion of the CWA trench is at a depth of 11 inches bd.

As per the contractual agreement with NPS, this top soil was removed by Greystone workers prior to the beginning of the archaeological field work. Hand excavations began 6 inches below datum (bd), and Level 1 extended from $0-12$ inches bd. In the eastern half of Units 1 and 3 the top of a caliche gravel bed was noted at approximately 9 inches bd. This caliche layer extended to the bottom of the level. Overall the artifacts found in Level 1 consisted of modern construction fill and a mixture of eighteenth-, nineteenth-, and twentieth-century materials (Table 2). The ceramic types recovered range from whitewares
Figure 4. Detail of the west wall of the western catch basin.

Figure 5. Close-up of the CWA wall reconstruction trench.

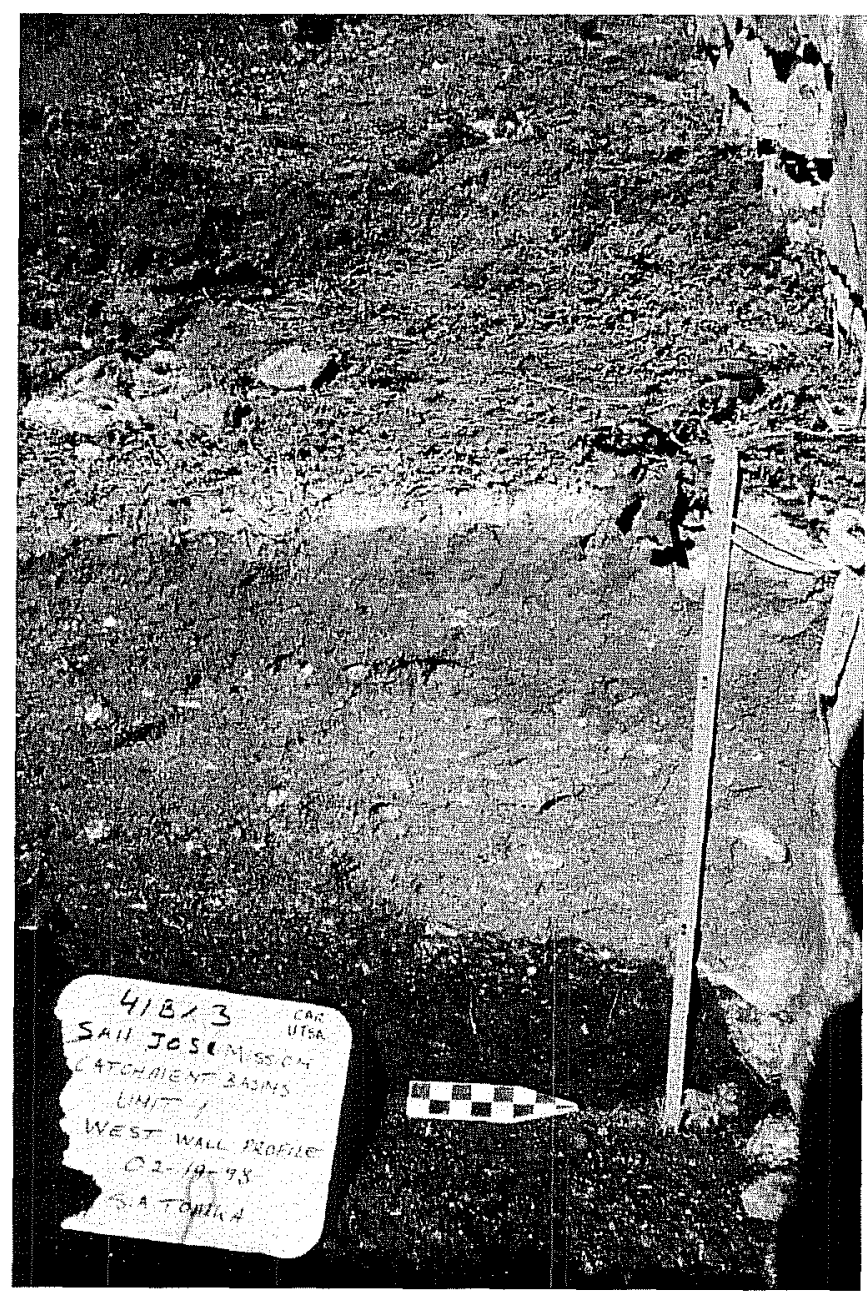


Table 2. Artifacts Recovered by Arbitrary Level from Units 1, 3, 5, and 6, West Basin

\begin{tabular}{|c|c|c|c|c|c|c|c|c|c|c|}
\hline Level & 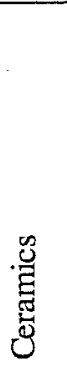 & 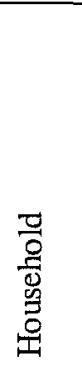 & $\begin{array}{l}\vec{\Xi} \\
0 \\
0.00 \\
0 \\
0.0\end{array}$ & 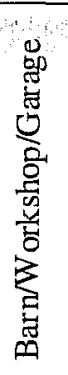 & 4 & 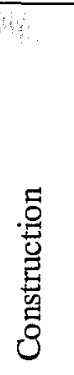 & $\frac{\pi}{\sum^{\frac{\pi}{2}}}$ & 苞 & 岕 & Total \\
\hline 1 & 121 & 128 & 4 & 1 & & 127 & 180 & 12 & 739 & 1312 \\
\hline 2 & 121 & 29 & 1 & & & 27 & 107 & 17 & 1916 & 2218 \\
\hline 3 & 89 & 7 & 2 & & & 19 & 7 & 8 & 1189 & 1321 \\
\hline 4 & 4 & 1 & & & & 2 & 3 & & 43 & 53 \\
\hline Total & 335 & 165 & 7 & 1 & 0 & 175 & 297 & 37 & 3887 & 4904 \\
\hline
\end{tabular}

'the bone column does not include 1 specimen from the surface of Unit 1

to the native-made Goliad 'wares. The next six inches (Level 2, 12-18 inches bd) consisted of a loose light gray-brown ashy matrix that contained primarily faunal remains, ceramics, metal objects and unidentifiable metal fragm :nts. Household items and construction materials occ ur in significantly lower frequencies. The number o chipped lithic artifacts is highest in this level. The rf covered ceramics include nineteenth century whitewa es, lead glazed specimens, and unglazed ceramics. $t$. terra-cotta brazier (see Feature Description) sit ing upside-down at an elevation of 16 inches bd $v$ as encountered in Unit 5 .

The upper two inches of L:vels 3 (18-24 inches bd) consisted of the gray-brown ashy deposit noted in higher levels. The remaining four inches consisted of mottled clayey matrix that represented the upper portion of the Houston Black clay substratum. The level yielded a mix of both eighteenth- and nineteenthcentury artifacts. The bulk of the materials recovered consisted of faunal remains and ceramics. Other materials occurred in small numbers. Goliad sherds dominate the ceramic sample. Near the top, Level 4 (24-30 inches bd) consisted of the mottled clay present in the bottom of Level 3. Below approximately 26 inches bd the mottling decreased significantly as did the frequency of artifacts encountered. Overall, there was a significant drop in the number of artifacts recovered from this level. Faunal remains and Goliad ceramics make up the bulk of the specimens.

\section{Units Excavated in Natural Levels} (Units 2 and 4)

As mentioned above, Units 2 and 4 were excavated following the natural strata evident in the eastern wall profiles of Units 1 and 3. The stratigraphy of these units and of the deposits found along the eastern half of the catch basin consisted of a 4-6-inch-thick modern top soil layer present along the entire length of the 18-ft profile (Figures 6 and 7). Underlying the top soil is a 14-16-inch-thick, gray-brown cultural zone present in Units 2, 4, and 6. Embedded within this cultural zone is a 4-6-inch-thick gravel caliche layer extending through all three units. This layer is cut through between Units 4 and 6 by a trench excavated to house a three inch diameter sprinkler pipe installed around 1965 (Figure 7). In Units 2, 4, and 6 the cultural zone extends 4-6 inches below the caliche layer. However, the caliche layer is 6-10 inches thick south of Unit 6 and sits directly on top of the Houston Black Clay substrata. An additional anomaly found within the cultural zone in Unit 2 is the rounded outline of the CWA construction trench dug to locate the colonial foundation (Figure 6). The Houston Black clay substrata is at approximately $16-18$ inches bd.

In both units, Level 1 (0-12 inches bd) consisted of the gravel caliche layer noted in the eastern half of Units 1 and 3. The caliche layer extended over the 


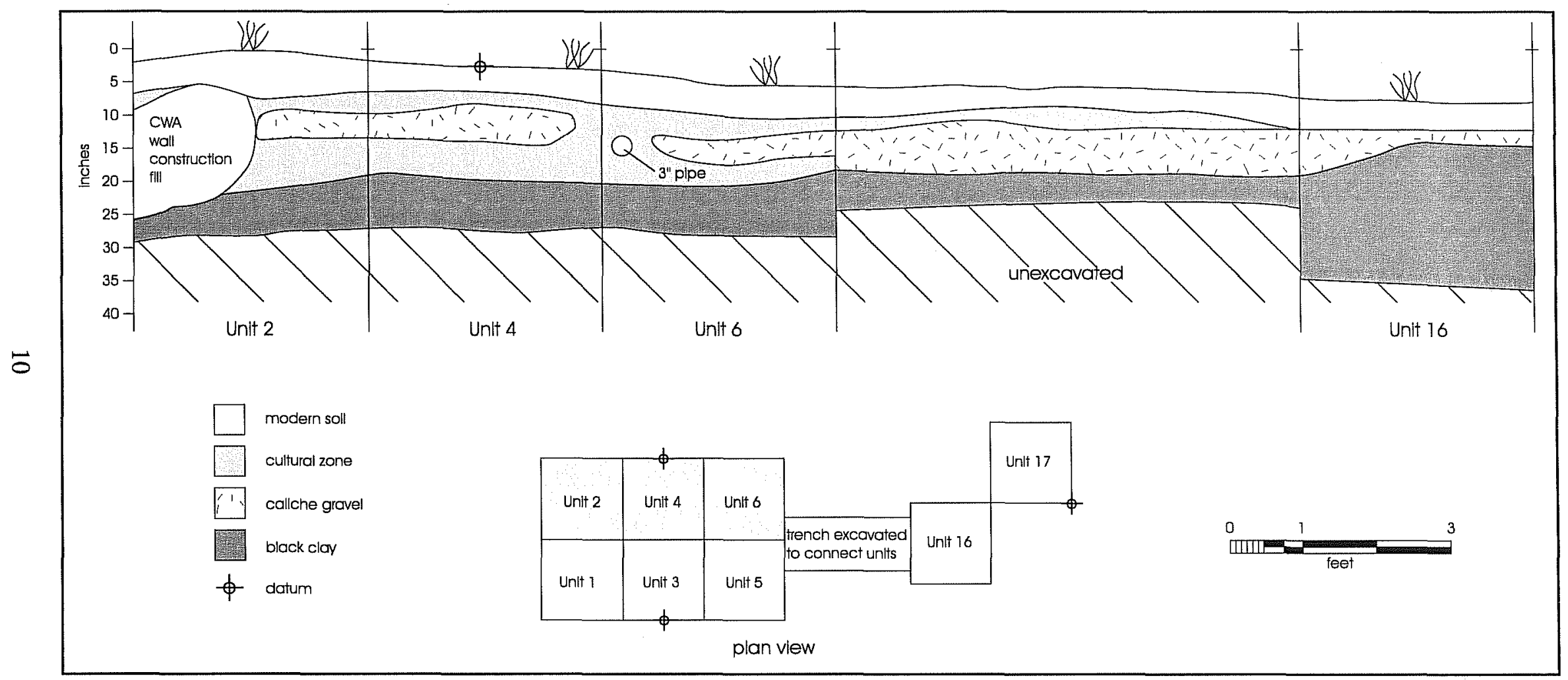

Figure 6. East wall profile of the western catch basin. 
entire surface of the units and was well compacted. Level 1 was terminated at the bottom of the caliche layer. The level contained a mix of eighteen- and nineteencentury materials, faunal remains, and chipped lithic artifacts (Table 3). In the southern half of Unit 2, Level 2 (12-16 inches bd) consisted of a 4-inch-thick, gray-brown clay loam matrix with scattered bones and a continued presence but smaller numbers of eighteenth- and nineteenth-century materials (Table 3). Level 2 in the northern half of the unit consisted of a light gray-brown sandy matrix with sandstone construction fill and limestone pebbles. This matrix is part of the

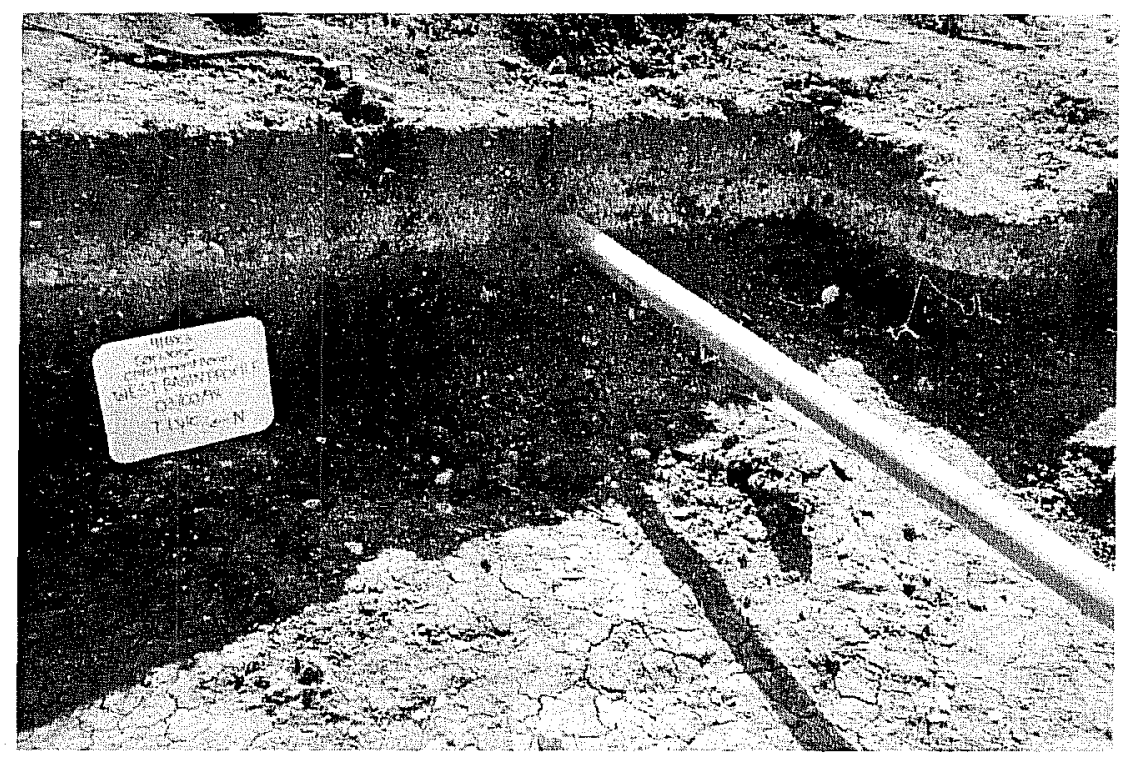

Figure 7. Detail of the east wall of the western catch basin. Note the light caliche layer.

Table 3. Artifacts Recovered by Natural Stratigraphy from Units 2 and 4, West Basin

\begin{tabular}{|c|c|c|c|c|c|c|c|c|c|c|}
\hline \multicolumn{11}{|c|}{ Unit 2} \\
\hline Level & 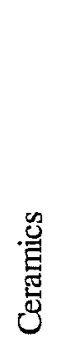 & 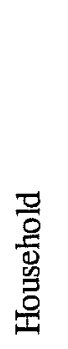 & $\begin{array}{l}\overrightarrow{\tilde{Z}} \\
\text { D. } \\
\text { D. } \\
\text { م. }\end{array}$ & 总 & 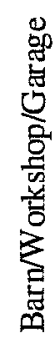 & 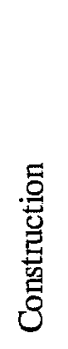 & $\frac{\pi}{\sum}$ & 岂 & 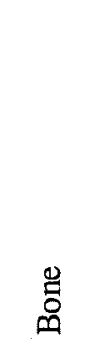 & Total \\
\hline 1 & 18 & 18 & 1 & 1 & & 23 & 19 & 1 & 183 & 264 \\
\hline 2 & 23 & 5 & & & & 14 & 18 & 1 & 290 & 351 \\
\hline 3 & 162 & & 1 & & & 4 & & 8 & 1380 & 1555 \\
\hline 4 & 3 & & & & & & 1 & & 17 & 21 \\
\hline Total & 206 & 23 & 2 & 1 & & 41 & 38 & 10 & $1870^{1}$ & 2191 \\
\hline
\end{tabular}

\begin{tabular}{|c|r|r|r|r|r|r|r|r|r|r|}
\hline \multicolumn{9}{|c|}{ Unit 4 } \\
\hline 1 & 26 & 27 & & & 1 & 15 & 13 & 7 & 4 & 93 \\
\hline 2 & 17 & 5 & & & & 2 & 3 & 1 & 109 & 137 \\
\hline 3 & 24 & 8 & & & & 3 & 4 & & 275 & 314 \\
\hline 4 & 117 & 2 & & & 1 & 1 & & 7 & 1161 & 1289 \\
\hline 5 & 36 & & & & & & & & 72 & 108 \\
\hline Total & 220 & 42 & 0 & 0 & 2 & 21 & 20 & 15 & 1621 & 1941 \\
\hline
\end{tabular}

${ }^{1}$ does not include 1 specimen from the surface of Unit 1 
CWA mission wall construction trench. Unglazed Goliad ware ceramics constitute 91 percent $(n=21)$ of the total number of ceramics $(n=23)$ recovered. The various construction items and metal fragments were recovered in the CWA construction trench. In Unit 4, Level 2(12-14 inches bd) consisted of a two-inchthick medium brown clayey soil mixed with sand and containing numerous small caliche pebbles. The number of nineteenthcentury materials was smaller than in the same level in Unit 2, and 88 percent $(n=15)$ of the total number of ceramics recovered are Goliad wares.

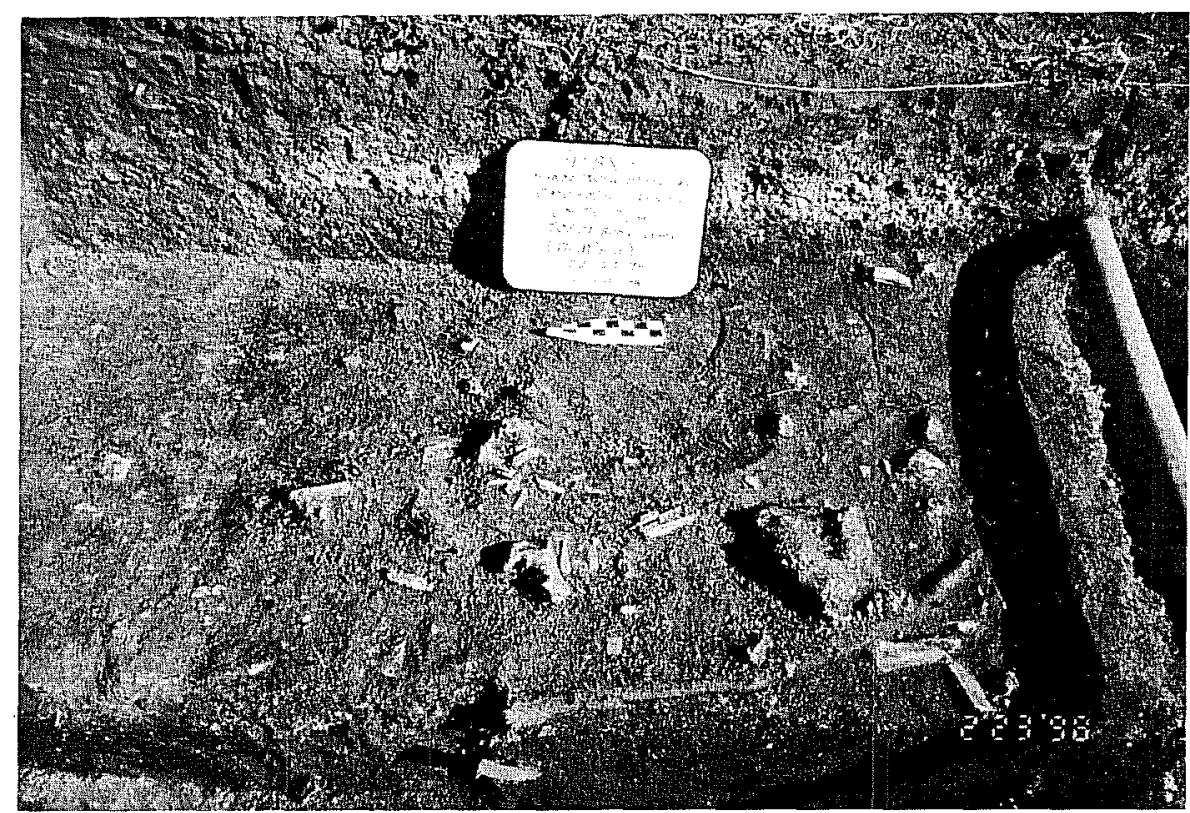

Figure 8. Top of the bone layer in Units 2 and 4, western catch basin.
In Unit 2, Level 3 (16-20 inches bd) consists of a dense bone layer in gray-brown clay loam (Figure 8). The upper portion of the level is a gray-brown matrix with little clay, while the lower half is mottled clay and represents the Houston Black clay substrata. The level contains the contact zone between the gray-brown cultural matrix and the Houston Black clay. The contains the bulk of the faunal remains and ceramics recovered from the unit (Table 3). All of the ceramics recovered are Goliad wares and only five artifacts are post-Colonial materials. Level 3 (14-15.5 inches bd) in Unit 4 consists of medium brown clayey soil with small caliche nodules and limestone rocks. The zone appears to be similar to Level 2 in Unit 2. It contained a small number of eighteenth- and nineteenth-century materials mixed with a moderate number of faunal remains and a small number of ceramics. All of the ceramics are unglazed Goliad wares $(n=24)$. In retrospect, it is likely that Level 2 and 3 in Unit 4 are the equivalent of Level 2 in Unit 2.

Similarly, Level 4 (15.5-20 inches bd) in Unit 4 is the equivalent of Level 3 in Unit 2 . The level contains the contact zone between the cultural zone and the Houston Black clay. Also, it contains the bulk of the faunal remains recovered from the unit and the large sample of ceramics consists entirely of unglazed Goliad wares. In addition, only four artifacts found in the level are post-colonial in origin. In Unit 2, all but the extreme northern edge of Level 4 (20-27 inches bd) is found entirely in the Houston Black clay. The northern portion of the unit still contains a small segment of the CWA construction trench at the top of the level. Nonetheless, overall the level contains few artifacts (Table 3), and the single unidentified metal fragment testifies to its disturbed nature. The excavation of Unit 2 was suspended at 27 inches bd.

Level 5 (20-26.5 inches bd) in Unit 4 is equivalent to Level 4 in the previous unit. It was excavated entirely in Houston Black clay. The top 2-3 inches contained some mottling possibly derived from bioturbation. The excavation of the level yielded a moderate number of faunal remains and ceramics. All of the ceramics are Goliad wares.

\section{Excavations of the Central Catch Basin: Units 7, 9-12, and 28}

All of the units in the central catch basin were excavated in six-inch levels (Figure 2). The east-west running sprinkler pipe noted between Units 3 and 5 in the western catch basin was encountered in Unit 11 . The pipe is located 90 inches south of the mission wall. Because a feature (see Feature Descriptions) was 
encountered in Unit 10 extending into the east wall of the unit it was decided to excavate the immediately adjacent unit (Unit 28), in lieu of Unit 8 which contained cultural materials disturbed by the CWA construction trench.

The artifacts recovered from the six units are listed in Table 4. As in the western catch basin, faunal remains dominate the artifacts recovered (see Faunal Analysis). Ceramics are the second most common artifact category, while construction materials, household items, and metal objects and fragments are present in moderate quantities. Nearly a hundred chipped lithic artifacts were recovered from the six units, while other artifact categories are infrequent.

The stratigraphy of the central catch basin consisted of a six-inch-thick layer of top soil against the base of the reconstruction wall. This layer was relatively evenly distributed across Units 7 and 9 and pinched to a thin lens along the southern half of catch basin (see Unit 11, Figure 9). Two relatively thin lenses of ashy and disturbed soil were encountered at the base of the layer of top soil (Figure 9). The next major stratigraphic unit consists of the thick grayish brown cultural zone that extends to the Houston Black clay substratum. The zone ranges from 10-14 inches in thickness and contains the bulk of the material remains recovered. A thin lens of ashy disturbed matrix is embedded in the zone just north of the sprinkler pipe in Units 11 and 9. In Unit 7 the cultural zone is cut through by the CWA reconstruction trench (Figure 9). The trench has a concave base and a rounded end opposite the reconstruction wall base. It extends to only 10 inches from the wall and it meets the wall at the top of the colonial foundation at a depth of 26.5 inches bs. The trench cuts into the Houston Black clay substratum. The top portion of the CWA trench is at a depth of 13.5 inches bs. The Houston Black clay occurred at a depth of 10-14 inches bd and was slightly deeper in the northern portion of the catch basin.

As in the case of all other areas associated with the catch basin construction, the first six inches of top soil were removed by Greystone workers prior to the beginning of the archaeological fieldwork. Hand excavations began six inches below datum (bd), and Level 1 began immediately above (Units 7, 9, 10, and 28 ) or in the upper portion (Units 11 and 12) of the cultural zone. The artifacts recovered from Level 1 consisted of a mix of eighteenth-, nineteenth-, and twentieth-century materials (Table 5). Bone was less common than in deeper levels and household items, construction materials, and metal fragments and objects were quite numerous. The ceramic types recovered consisted of numerous Goliad wares accompanied by a small number of whitewares, and lead and tin glazed specimens. Chipped lithic artifacts

Table 4. Artifacts Recovered from Central Catch Basin Excavation Units

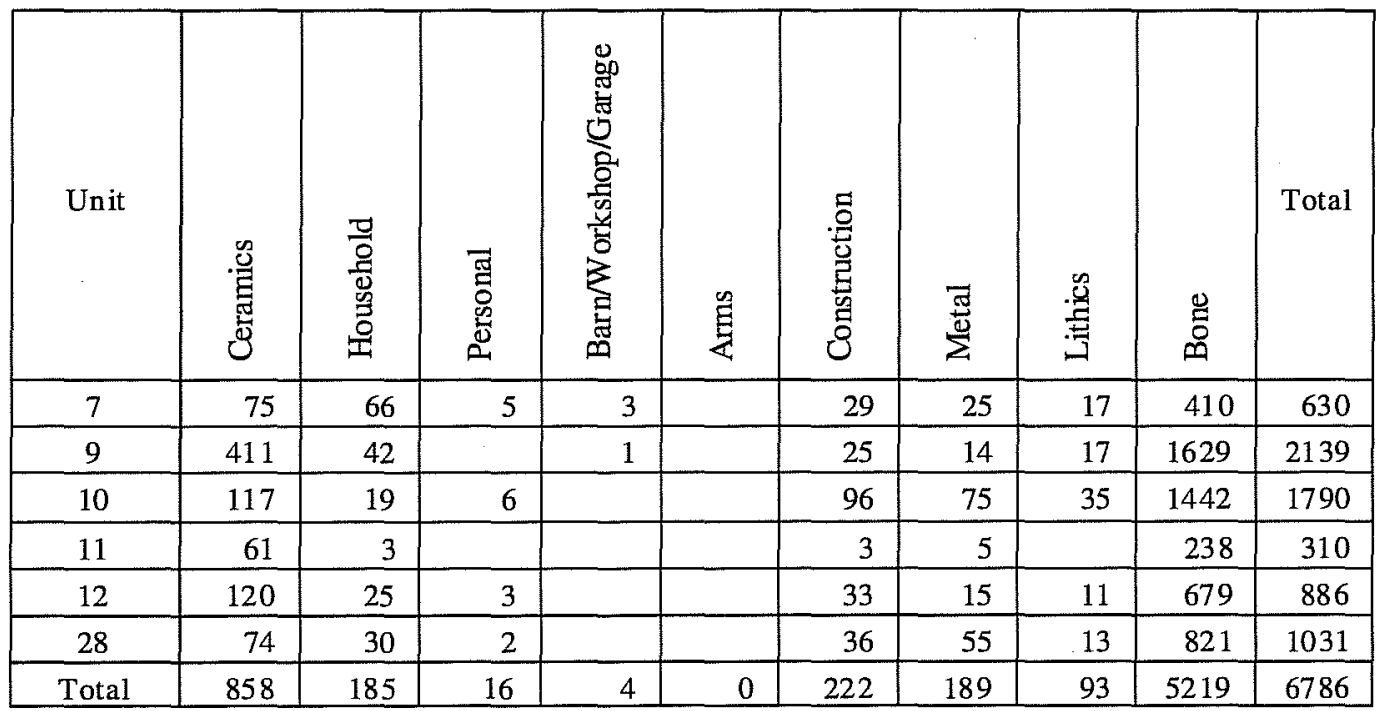




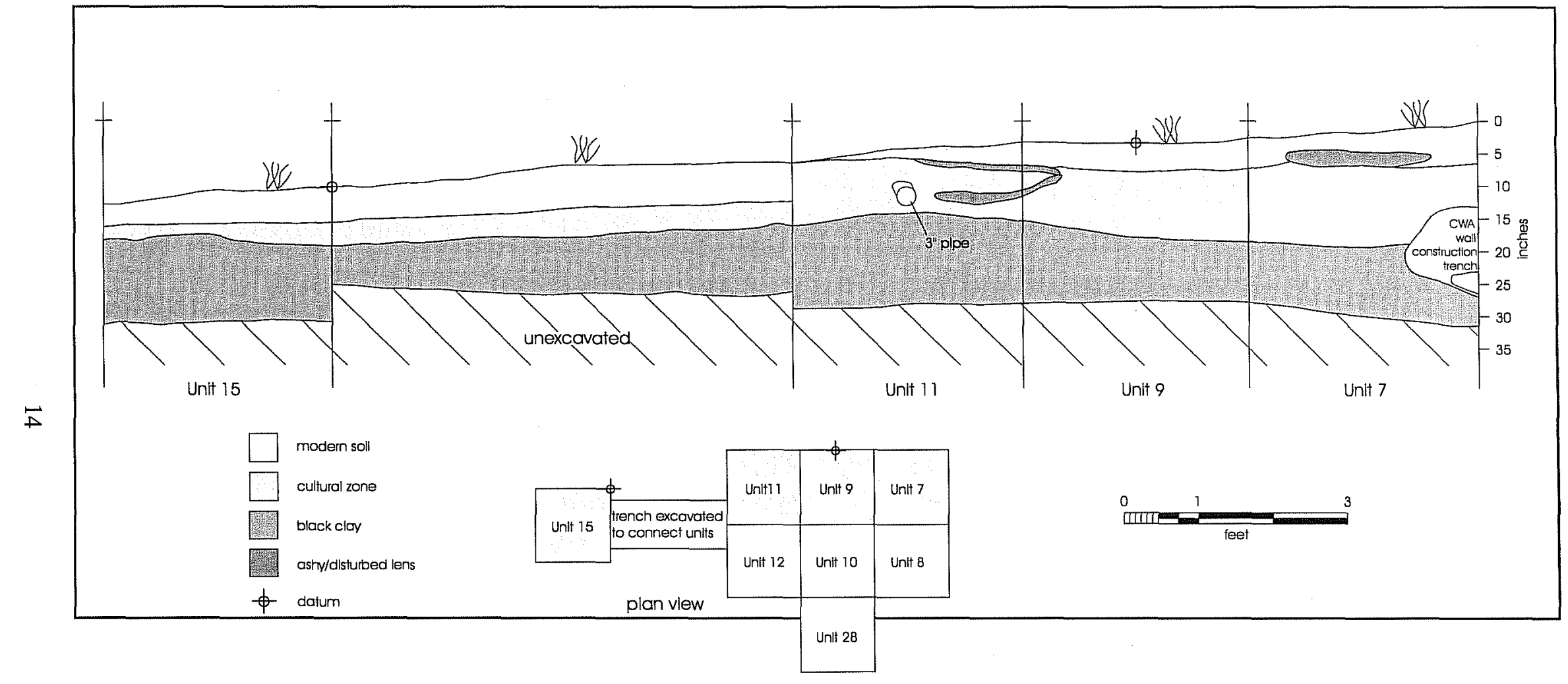

Figure 9. West wall profile of the central catch basin. 
Table 5. Artifacts Recovered by Arbitrary Level from the Central Basin, Units 7, 9-12, and 28

\begin{tabular}{|c|c|c|c|c|c|c|c|c|c|c|}
\hline Level & 总 & 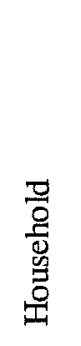 & 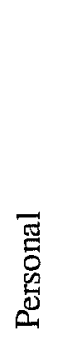 & 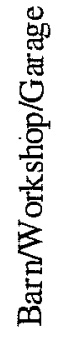 & 是 & 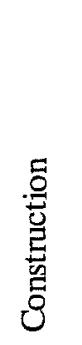 & 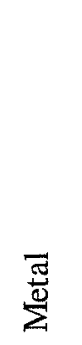 & 资 & 苛 & Total \\
\hline 1 & 118 & 168 & 12 & 4 & & 144 & 149 & 44 & 511 & 1150 \\
\hline 2 & 330 & 11 & 4 & & & 47 & 21 & 25 & 3106 & 3544 \\
\hline 3 & 395 & 2 & & & & 7 & 9 & 19 & 1532 & 1964 \\
\hline 4 & 2 & 2 & & & & & & & 8 & 12 \\
\hline 5 & & & & & & & & & & 0 \\
\hline Total & $845^{1}$ & $183^{2}$ & 16 & 4 & 0 & $198^{3}$ & $179^{4}$ & $88^{5}$ & $5157^{\circ}$ & 6670 \\
\hline
\end{tabular}

${ }^{1}$ does not include 13 specimens from Feature 2 Units 10 and 28

${ }^{2}$ does not include 2 specimens from Feature 2, Units 10 and 28

${ }^{3}$ does not include 24 specimens from Feature 2, Units 10 and 28

${ }^{4}$ does not include 10 specimens from Feature 2, Units 10 and 28

5 does not include 5 specimens from Feature 2, Units 10 and 28

${ }^{6}$ does not include 62 specimens from Feature 2, Units 10 and 28

were more numerous than in deeper levels. The upper 3-4 inches of Level 2 (12-18 inches bd) consisted of a loose light gray-brown ashy cultural matrix. The bottom 2-3 inches consisted of mottled clay that represented the upper portion of the Houston Black clay. This level contained an abundance of faunal remains and ceramics. Construction materials, metal objects and unidentifiable metal fragments, and household items occur in significantly smaller numbers than in Level 1. The recovered ceramics consist primarily of unglazed Goliad wares. The next six inches (Levels 3, 18-24 inches bd) of mottled Houston Black clay contained an abundance of faunal remains and ceramics. All of the large sample of ceramic fragments were Goliad wares. Level 4 (24 30 inches bd) was excavated in Units 7, 9, 11, and 12. It was contained entirely within the Houston Black clay substratum. Mottling was present only in the upper two inches of the level. Only 12 artifacts were recovered and consisted of faunal remains, ceramics and household items.

\section{Excavations Along the Connecting and Main Pipe Trenches: Units 13-27}

Fifteen units were excavated along the trenches designed to house the connecting and main pipes draining the three catch basins (Figure 2). Of these, four (Units 13-16) were excavated in the trenches connecting the basins to the main conduit. The remaining 11 (Units $17-27$ ) were excavated along the main pipe trench. All of the units were excavated in six inch levels. A north-south running sprinkler pipe probably connecting to the east-west running pipe noted in the western and central catch basins was encountered in Unit 27, at a depth of 24 inches bs. The pipe is located along the western edge of the unit only about five feet from the edge of the side walk leading through the east gate of the mission.

The artifacts recovered from the 11 units are listed in Table 6. As in the two catch basins, faunal remains dominate the artifacts recovered (see Faunal Analysis). Ceramics and metal objects and unidentifiable 
Table 6. Artifacts Recovered from Excavation Units in Pipe Trenches, Units 13-27

\begin{tabular}{|c|c|c|c|c|c|c|c|c|c|c|}
\hline Unit & $\frac{\mathscr{O}}{\stackrel{0}{\mathbb{Z}}}$ & $\begin{array}{l}\text { 믕 } \\
\frac{0}{0} \\
\frac{9}{0} \\
\text { 夏 }\end{array}$ & 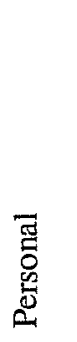 & 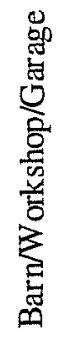 & 龺 & 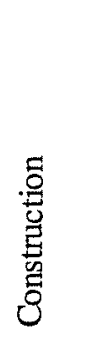 & 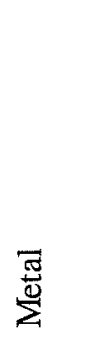 & 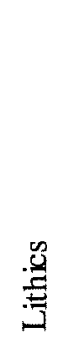 & 号 & Total \\
\hline 13 & 93 & 47 & 1 & & & 143 & 138 & 5 & 1167 & 1594 \\
\hline 14 & 51 & 70 & 3 & 1 & & 61 & 77 & 6 & 249 & 518 \\
\hline 15 & 23 & 28 & & & & 28 & 18 & 2 & 266 & 365 \\
\hline 16 & 7 & 12 & & & & 8 & 2 & & 258 & 287 \\
\hline 17 & 55 & 73 & 1 & & & 47 & 25 & 7 & 467 & 675 \\
\hline 18 & 22 & 72 & 2 & & 2 & 26 & 1 & 2 & 86 & 213 \\
\hline 19 & 105 & 44 & 2 & & 1 & 43 & 64 & 5 & 308 & 572 \\
\hline 20 & 37 & 32 & 2 & 3 & & 74 & 46 & 2 & 195 & 391 \\
\hline 21 & 23 & 28 & & 1 & & 39 & 10 & 1 & 539 & 641 \\
\hline 22 & 39 & 49 & 2 & & & 44 & 28 & . & 857 & 1019 \\
\hline 23 & 35 & 60 & & & & 31 & 76 & 1 & 96 & 299 \\
\hline 24 & 65 & 66 & 1 & & & 34 & 31 & 10 & 1137 & 1344 \\
\hline 25 & 31 & 19 & & & & 24 & 21 & 12 & 458 & 565 \\
\hline 26 & 50 & 38 & 4 & 1 & & 77 & 57 & 4 & 134 & 465 \\
\hline 27 & 40 & 58 & & & & 32 & 86 & 13 & 124 & 353 \\
\hline Total & 676 & -96 & 18 & 6 & 3 & 711 & 680 & 70 & 6341 & 9301 \\
\hline
\end{tabular}

fragments are the second most common artifact category, while household ite:ns and construction materials are present in moderale quantities. A small number of chipped lithic artifacts was recovered with the highest frequencies derived from units located closer (Units 24, 25, and 27) to the east gate of the mission. Personal items, barn/workshop/garage items, and arms were infrequent.

Although distributed over a distance of $102 \mathrm{ft}$ along the south wall of the mission, the stratigraphy of the 11 units is similar because of the distance they are located from the base of the wall and the similar soil disturbances the area has undergone during modern times. In general, the stratigraphy of the eleven units consisted of a 4-8-inch-thick layer of top soil. This top soil appears to have been spread across the area following the 1965 installation of the sprinkler system. It is between 4-6 inches thick between $18-21 \mathrm{ft}$ from the base of the south wall and it thickens to 8 inches at a distance of $15 \mathrm{ft}$ from the wall. The resulting slope may have been designed to provide drainage away from the wall base. The next stratigraphic unit consists of the grayish brown cultural zone noted in the two catch basins. While this cultural zone is $14-15$ inches thick in the western catch basin adjacent the base of the south wall, it is reduced to a 2-6-inch-thick lens in Units 16 and 17 (see Figure 3) along the west end of the trench. It is similarly thin in Unit 15 (see Figure 9) in the central portion of the trench, and in Unit 24 (Figure 10) along the eastern portion. While the Houston Black clay substratum occurred at a depth of between 20-24 inches bs adjacent the wall base, it was only at a depth of 10-12 inches bs in the main drainage pipe trench.

The first six inches of top soil were removed by Greystone workers prior to the beginning of the 
archaeological field work. Hand excavations began six inches below the original surface and Level 1 (0-12 inches bd) contained the bottom portion of the top soil and the cultural zone. Often, Level 1 ended at the contact between the clay substratum and the cultural zone. In some instances (Units 18, 20, 21 , and 22), however, Level 1 ended 1-2 inches below the contact zone in the clay substratum. The artifacts recovered from Level 1 consisted of a mix of eighteenth-, nineteenth-, and twentieth-century materials

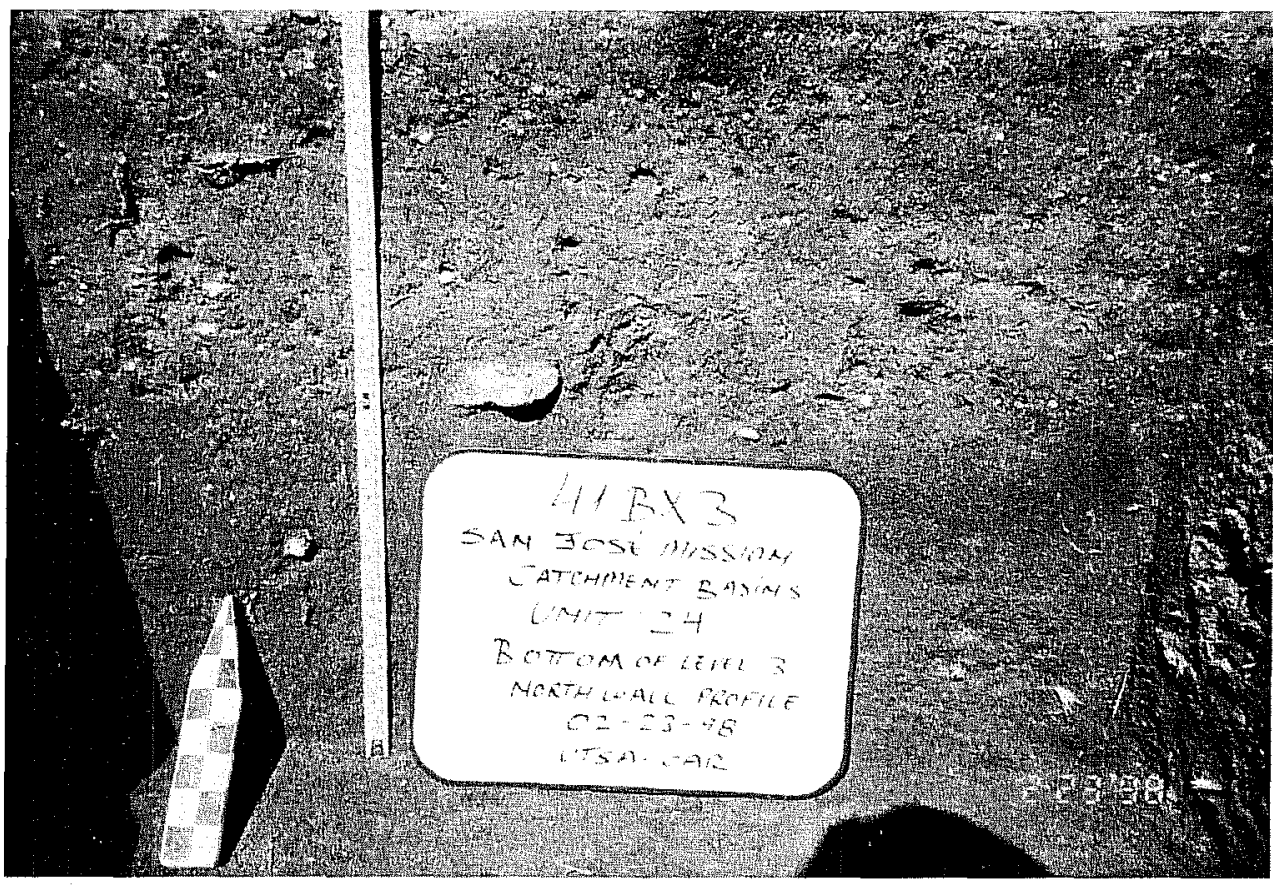

Figure 10. North wall profile of Unit 24 . The cultural zone is the light gray layer above the photo board and the dark topsoil at the top of the photo.
(Table 7). Faunal remains

were more common than in deeper levels and household items, construction materials, and metal fragments and objects were quite numerous. The ceramic types recovered consisted of numerous Goliad wares accompanied by moderate numbers of whitewares, and lead and tin glazed specimens. Chipped lithic artifacts also were more numerous than in deeper levels. Level 2 (12-18 inches bd) consisted of mottled clay that represented the upper portion of the Houston Black clay. This level contained nearly as many faunal remains as Level 1 . However, the ceramics recovered constitute only about a fourth of the sample obtained from the previous level. Household items, metal objects and unidentifiable metal fragments, and construction materials also occurred in significantly smaller numbers than in Level 1. The ceramics recovered consist primarily of unglazed Goliad wares ( $n=80,60$ percent) and

Table 7. Artifacts Recovered from Excavation Units in Pipe Trenches, Units 13-27

\begin{tabular}{|c|c|c|c|c|c|c|c|c|c|c|}
\hline Level & 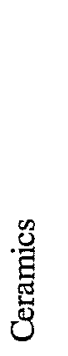 & $\begin{array}{l}\text { 흥 } \\
\text { 욥 } \\
0 \\
0 \\
0 \\
0\end{array}$ & 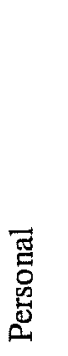 & 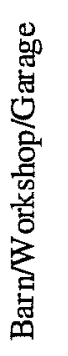 & 宸 & 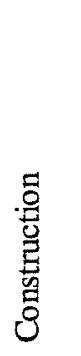 & 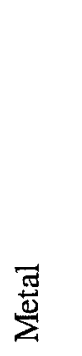 & 苞 & 岇 & Total \\
\hline 1 & 526 & 715 & 14 & 5 & 3 & 670 & 603 & 37 & 3094 & 5667 \\
\hline 2 & 134 & 72 & & 1 & & 24 & 66 & 30 & 2821 & 3148 \\
\hline 3 & 16 & 9 & 4 & & & 17 & 11 & 3 & 426 & 486 \\
\hline Total & 676 & 796 & 18 & 6 & 3 & 711 & 680 & 70 & 6341 & 9301 \\
\hline
\end{tabular}


whitewares. The upper 3-4 inches of Levels 3 (18-24 inches bd) consisted of mottled Houston Black clay. The remaining 2-3 inches of the level were characterized by minimal mottling. Most of the artifacts recovered from this level were found in the upper four inches. Faunal remains dominate the sample of artifacts obtained. Interestingly, ceramics, construction materials, metal objects and unidentifiable fragments, and household items occur in small but similar numbers. Although Goliad wares are the most common among the small sample of ceramics $(n=9,56$ percent), small numbers of post-Colonial ceramics also are present.

\section{Feature Descriptions}

Two features were identified during the catchment basin excavations. Feature 1 is a brazier; Feature 2 consists of two intersecting hearths.

\section{Feature 1}

Feature 1 is a portion of a historic-period brazier (see Artifact Descriptions). It was encountered in Unit 5 (Figure 11), lying face down with its rim 16 inches below the present ground surface. Its base was exposed at a depth of only 10.5 inches below the present ground surface and only six inches south of the sprinkler pipe running along the north wall of the unit. Heavy charcoal staining was noted immediately adjacent the brazier. Unburned cow bones, mainly foot elements, were found below and in its vicinity. The bones were unburned and were not in primary (behavioral) association with the discard of the brazier.

\section{Feature 2}

Feature 2, consists of two intersecting hearths extending across Units 10 and 28 of the central catch basin (Figure 12). The western hearth in Unit 10 was

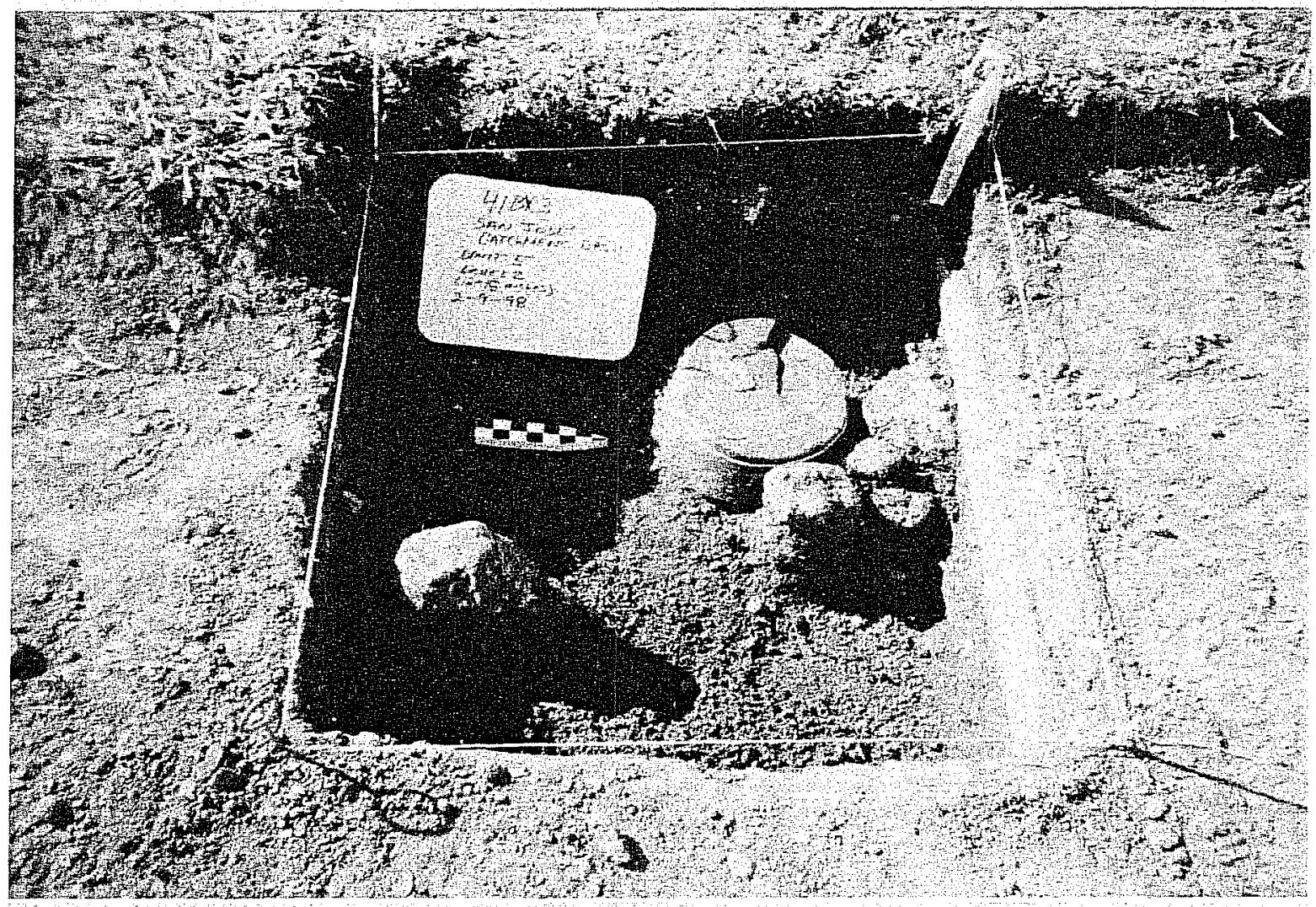

Figure 11. Feature 1, historic brazier in Unit 5. 


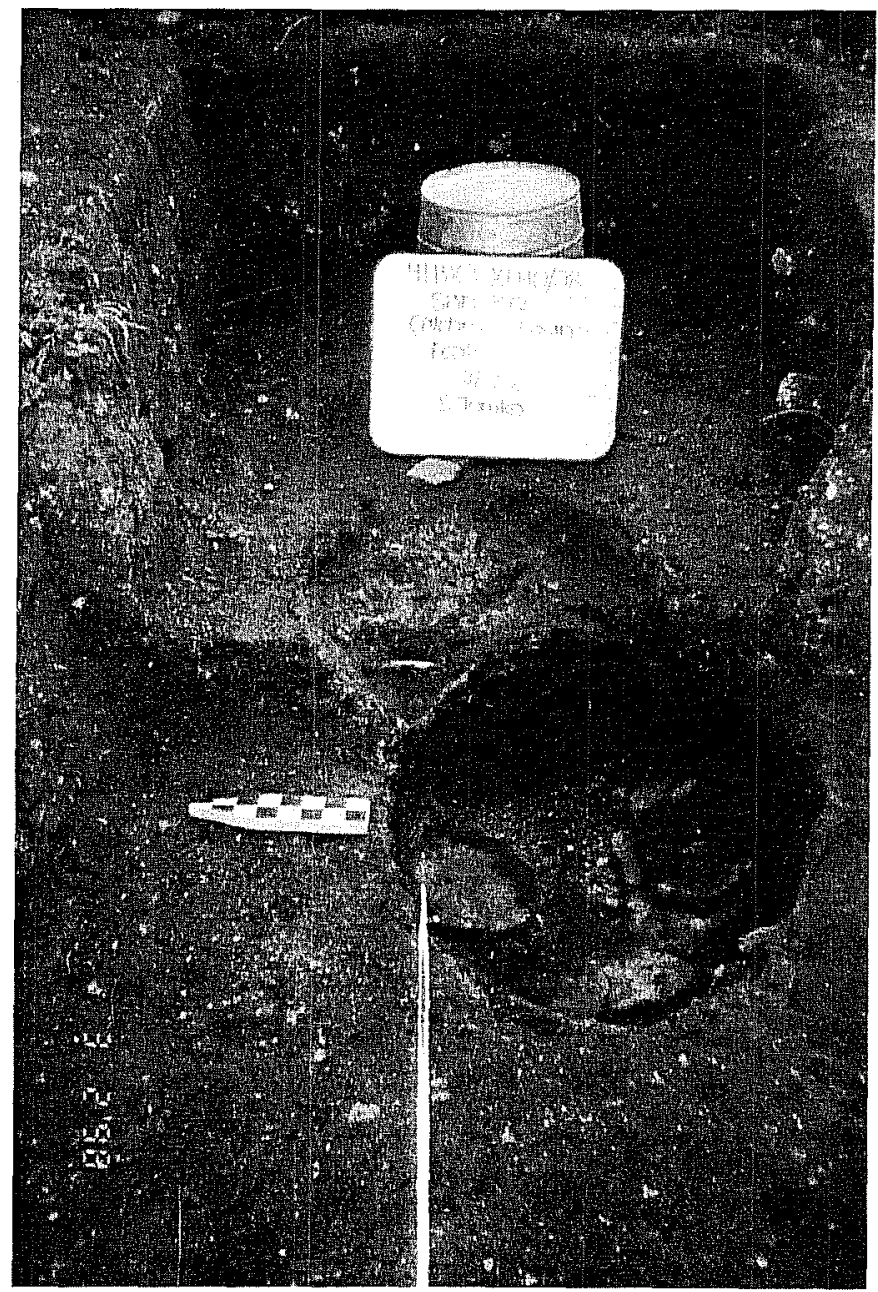

Figure 12. Feature 2, inter ecting historic hearths in Units 10 and 28 , centra' catch basin.

oval and measured approx mately $26 \times 20$ inches. It had vertical walls and its oase was lined with three sandstone slabs (Figure 13). Although a partial indication of the hearth's presence was noted approximately 12 inches bd, a clearly identifiable outline was evident only at a depth of 16 inches bd. The base of the hearth where the sandstone slabs rested was at 23 inches bd. This hearth contained large quantities of charcoal and very little ash. All the matrix was bagged and screened in the lab using $1 / 8$-inch hardware cloth. Twenty-four artifacts were recovered from the screen: 9 Goliad ware ceramic fragments, 7 wire nails, 4 unidentifiable metal fragments, 2 flakes, a piece of bone, and a single piece of glass.

The hearth in Unit 28 was roughly circular in shape and measured approximately 18 inches in diameter. It had straight walls and contained superimposed lenses of ash and unburned soil. The northern rim of the hearth was first noted at a depth of 10 inches bd in the east wall profile of Unit 10. All matrix from within the hearth was bagged and returned to the lab where it was screened through $1 / 8$-inch hardware cloth. Mixed within the ash were 45 artifacts: 15 wire nails, 14 bone fragments, 4 ceramics ( 3 Goliad, 1 whiteware), 3 flakes, 2 pieces of hardware, and a medicine bottle. The unbroken, unburned, machinemade medicine bottle was recovered near the bottom of the hearth, resting at a depth of 20 inches bd (Figure 14). Machine-made bottles began to be manufactured after 1903 and it is likely that the bottle was first used before 1920 (see Artifacts Recovered).

Based on the collection of artifacts recovered from within the two intersecting hearths in combination with the depth bs at which they were discovered, it is clear that they were constructed during the early 1900s, probably between 1903 and 1920 . The fact that the hearth in Unit 10 crosscuts the western edge of the hearth in Unit 28 indicates that the westernmost hearth was the last one to be dug. However, this sequence of events does not mean that the two were not functionally related. Indeed, the fact that one of the hearths (in Unit 10) contained mainly charcoal while the other (in Unit 28) contained mainly ash suggests a functional relationship. 

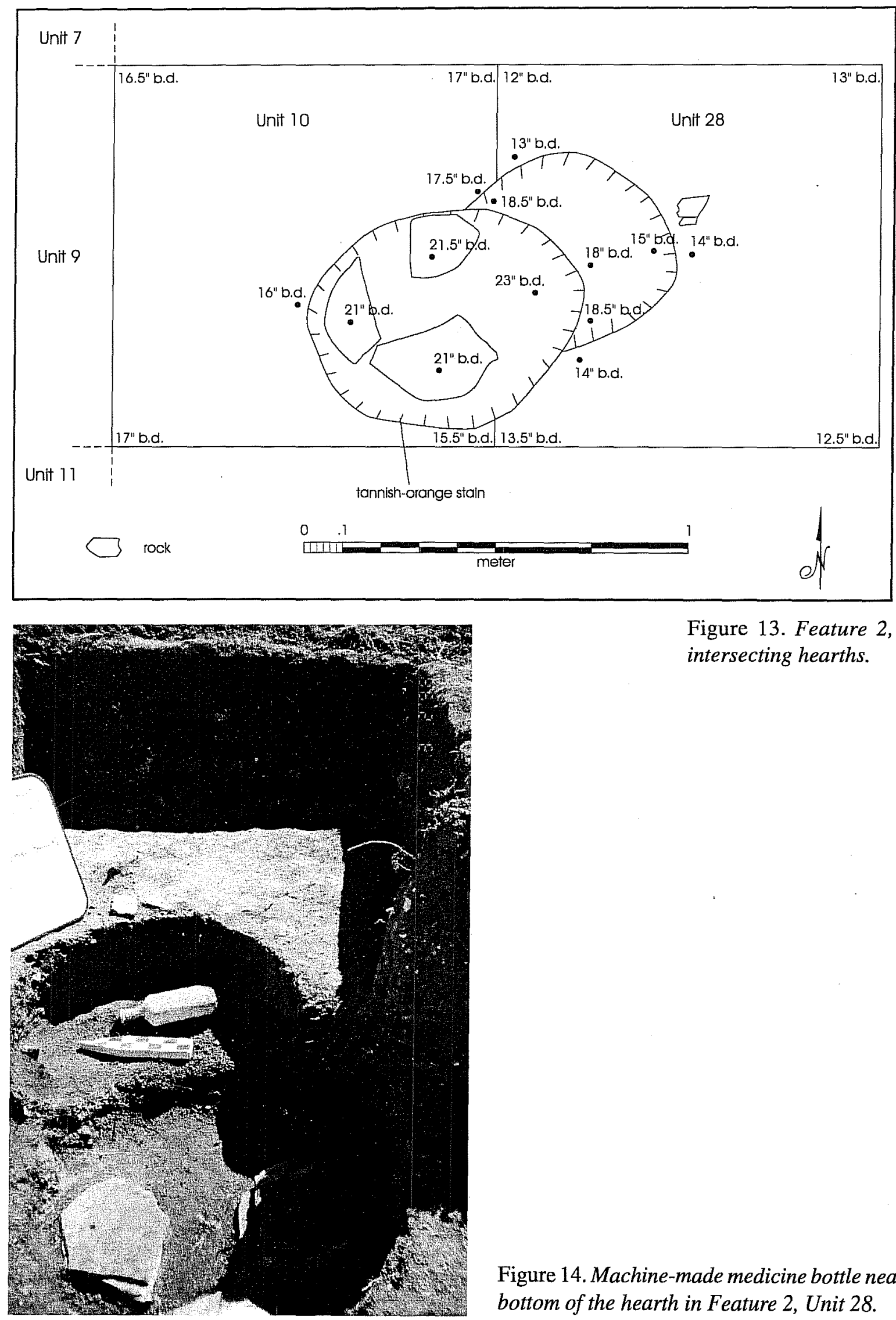

Figure 13. Feature 2, intersecting hearths.

Figure 14. Machine-made medicine bottle near the bottom of the hearth in Feature 2, Unit 28. 


\section{The Artifacts}

\section{Anne A. Fox and Steve A. Tomka}

The artifact assemblage found during this project contains objects which are commonly found on all Spanish colonial and early-nineteenth century occupation sites in the San Antonio area. The categories include ceramics, glass, and metal as well as shell, bone, and lithics (Table 8). The eighteenthcentury artifacts were directly connected with the occupation of the site by the mission inhabitants. The nineteenth century items were probably deposited by the later vecinos or citizens of the San José community that grew up on the mission site. The following descriptions are limited to artifacts that are useful for interpretation of the site.

\section{Ceramics}

Of the artifacts recovered from a Spanish mission site, the ceramics are the most useful for dating the deposits since they changed regularly in style and technique of manufacture throughout the eighteenth and nineteenth centuries. A chronology of South Texas historic ceramics is shown in Figure 15 (modified from Hard et al. 1995). Therefore, the analysis of the deposits found in this project relies strongly on the ceramic fragments recovered. This is then confirmed by the approximate dating of other types of artifacts found with them.

A sample of 2,295 ceramics was recovered from this project at Mission San José. The majority of these $(\mathrm{n}=2,278,99$ percent) were grouped into 8 types (Tables 9 and 10). The remaining $(n=17,1$ percent) were included in a miscellaneous "other" group.

\section{Unglazed Wares}

Most of the ceramics from Mission San José are unglazed wares ( $n=1,801,78$ percent) (Table 9). In general, several types of unglazed ceramic wares are usually found on Spanish sites in the San Antonio area. A total of three types (Table 11) were identified in the collection. They include the locally-made hand-built ware commonly called Goliad ware $(n=1,727,96$ percent of unglazed), and occasional examples of hand-built wares probably made by Indian groups in Mexico.

Goliad ware has a distinctive red brown to dark brown color on the exterior and usually has a black core, due to low firing temperatures. It contains bone tempering and appears identical to the Leon Plain ceramics of the Late Prehistoric period in South Texas. Spanish colonial artifact inventories in the San Antonio and Guadalupe River valleys are dominated by this ceramic type, strongly suggesting that it originated among the Indians of the South Texas area (Fox et al. 1976:67). The Colonial ceramics from this project reflect this same distribution.

Two types of unglazed burnished wares are common on mission sites in San Antonio. Both appear to be direct descendants of pre-Columbian traditions in Mexico. A tan-bodied ware with burnished red slip or burnished red, black, and yellow slip-painted designs has been identified as coming from Tonalá, Jalisco (Charlton and Katz 1979). Eight (.5 percent of unglazed) sherds of this type were found in these excavations. A burnished ware with red body commonly occurs in Spanish colonial sites. Two (.1 percent of unglazed) sherds of this ware were recovered from this site.

Sixty-four (four percent of unglazed) other unidentified sherds of unglazed wares were recovered, mostly too small to be positively identified. Several from Level 1 in Units 1,2 , and 3 may possibly be fragments of sewer tile. One from Level 2 in Unit 20 and one from Level 3 in Unit 1 may be from wheelturned Mexican ollas of a type called Valero ware (Fox et al. 1976:67), but they are too small to be sure.

In Levels 1 and 2 of Unit 5 the nearly intact bottom section of a ceramic brazier or charcoal heater was found (Figure 16). It measures eleven inches in diameter and four inches high, and the walls are $5 / 8$ of an inch thick. These braziers were commonly used in San Antonio houses around the turn of the century (Georgeanna Greer, personal communication 1998) and fragments of them have been found in most house sites of that time period. 
Table 8. Artifacts Recovered from All Excavation Units

\begin{tabular}{|c|c|c|c|c|c|c|c|c|c|c|}
\hline Unit & 兽 & 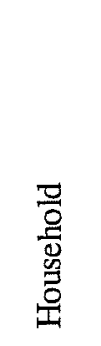 & 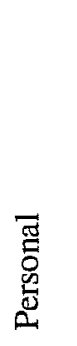 & 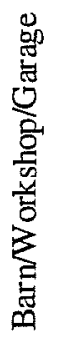 & 㚆 & 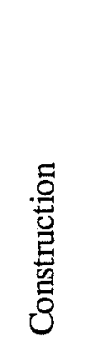 & 焉 & 串 & 号 & Total \\
\hline 1 & 91 & 59 & & & & 59 & 54 & 9 & 1092 & 1364 \\
\hline 2 & 206 & 23 & 2 & & 1 & 41 & 38 & 10 & 1870 & 2191 \\
\hline 3 & 62 & 53 & 6 & & & 32 & 68 & 13 & 1292 & 1526 \\
\hline 4 & 220 & 42 & & 2 & & 21 & 20 & 15 & 1621 & 1941 \\
\hline 5 & 100 & 35 & 1 & & & 69 & 173 & 8 & 940 & 1326 \\
\hline 6 & 82 & 18 & & 1 & & 15 & 2 & 7 & 564 & 689 \\
\hline 7 & 75 & 66 & 5 & 3 & & 29 & 25 & 17 & 410 & 630 \\
\hline 9 & 411 & 42 & & 1 & & 25 & 14 & 17 & 1629 & 2139 \\
\hline 10 & 117 & 19 & 6 & & & 96 & 75 & 35 & 1442 & 1790 \\
\hline 11 & 61 & 3 & & & & 3 & 5 & & 238 & 310 \\
\hline 12 & 120 & 25 & 3 & & & 33 & 156 & 11 & 679 & 1027 \\
\hline 13 & 93 & 47 & 1 & & & 143 & 138 & 5 & 1167 & 1594 \\
\hline 14 & 51 & 70 & 3 & 1 & & 61 & 77 & 6 & 249 & 518 \\
\hline 15 & 23 & 28 & & & & 28 & 18 & 2 & 266 & 365 \\
\hline 16 & 7 & 12 & & & & 8 & 2 & & 258 & 287 \\
\hline 17 & 55 & 73 & 1 & & & 47 & 25 & 7 & 467 & 675 \\
\hline 18 & 22 & 72 & 2 & & 2 & 26 & 1 & 2 & 86 & 213 \\
\hline 19 & 105 & 44 & 2 & & 1 & 43 & 64 & 5 & 308 & 572 \\
\hline 20 & 37 & 32. & 2 & 3 & & 74 & 46 & 2 & 195 & 391 \\
\hline 21 & 23 & 28 & & 1 & & 39 & 10 & 1 & 539 & 641 \\
\hline 22 & 39 & 49 & 2 & & & 44 & 28 & & 857 & 1019 \\
\hline 23 & 35 & 60 & & & & 31 & 76 & 1 & 96 & 299 \\
\hline 24 & 65 & 66 & 1 & & & 34 & 31 & 10 & 1137 & 1344 \\
\hline 25 & 31 & 19 & & & & 24 & 21 & 12 & 458 & 565 \\
\hline 26 & 50 & 138 & 4 & 1 & & 77 & 57 & 4 & 134 & 465 \\
\hline 27 & 40 & 58 & & & & 32 & 86 & 13 & 124 & 353 \\
\hline 28 & 74 & 30 & 2 & & & 36 & 55 & 13 & 821 & 1031 \\
\hline Total & 2295 & 1211 & 43 & 13 & 4 & 1170 & 1365 & 225 & 18938 & 25265 \\
\hline
\end{tabular}




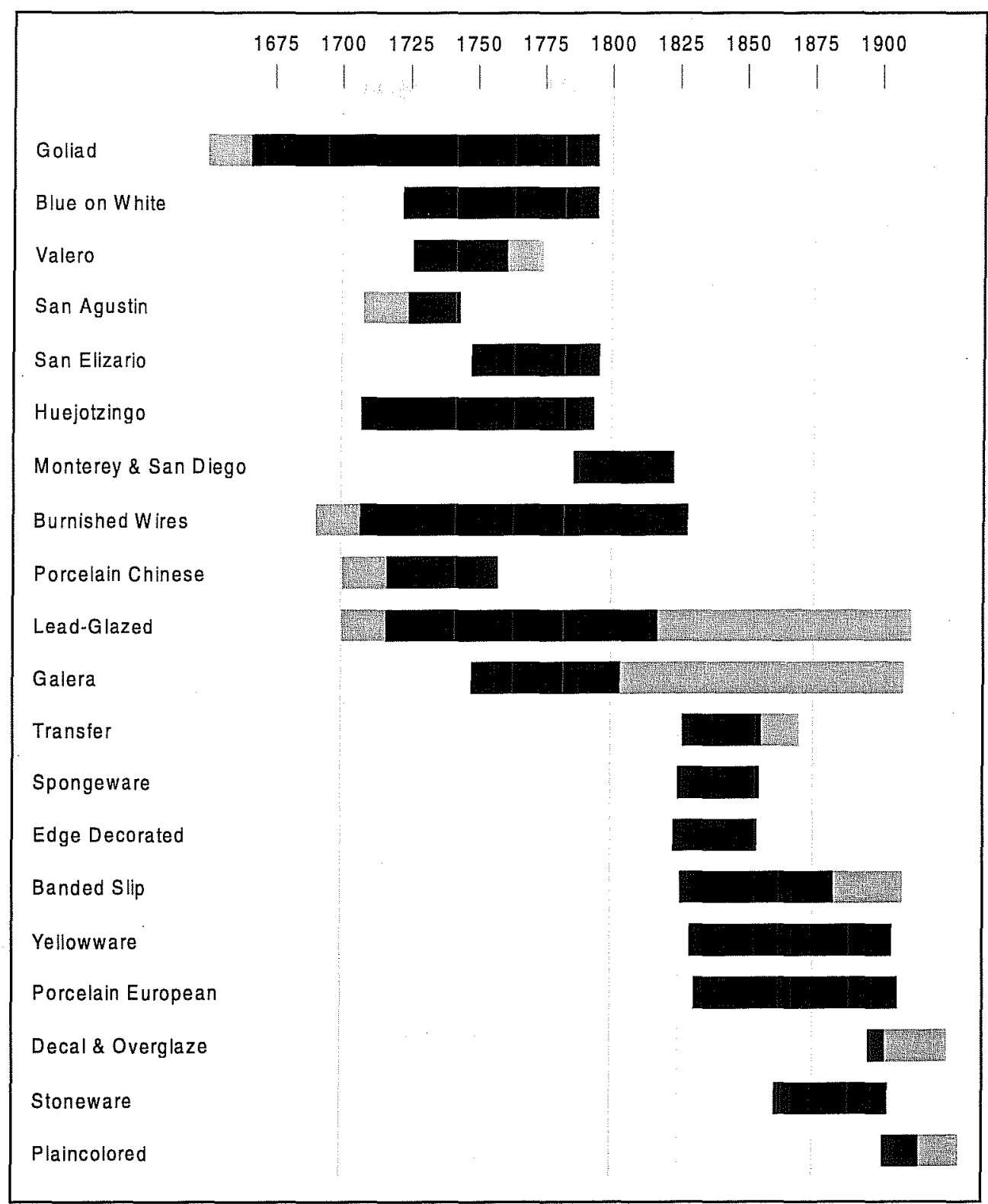

Figure 15. Chronology of South Texas historic ceramics.

\section{Lead-Glazed Utility Wares}

The 69 ( 3 percent of total) lead-glazed sherds include four types usually found on mission sites (Table 12). All sherds are too small to determine much about vessel shapes or sizes. The vessels were probably made in Mexico and carried to the frontier in the annual shipment of supplies.

Bowls and jars of sandy paste earthenware are predominant among the lead glazed vessels in eighteenth century deposits. The glaze is clear or very pale green, exposing the intensifying the color of the pink-to-orange paste beneath (Fox 1974:56). This collection contains 51 (74 percent of lead glazed) sherds of this type of ware.

Also present, in deposits dating after 1750 , are thinner orange sherds covered on the inside and over the rim onto the outside with a clear, thin lead glaze. Chocolateros and bean pots of this ware are often decorated with brown, yellow, and occasionally green floral designs. The term Galera ware is accepted for 
Table 9. Ceramic Types by Unit

\begin{tabular}{|c|c|c|c|c|c|c|c|c|c|c|}
\hline Unit & 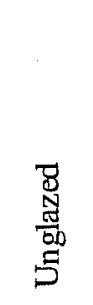 & 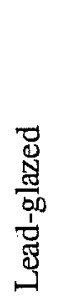 & 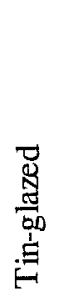 & 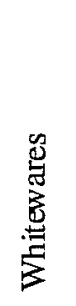 & 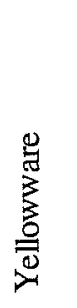 & 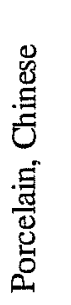 & 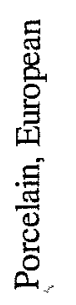 & $\underset{\stackrel{D}{0}}{\stackrel{D}{心}}$ & $\frac{w}{\mathscr{D}}$ & Totals \\
\hline 1 & 68 & 2 & 2 & 16 & 1 & & 1 & 1 & & 91 \\
\hline 2 & 197 & 1 & 0 & 5 & & & 3 & & & 206 \\
\hline 3 & 51 & 0 & 1 & 9 & & 1 & & & & 62 \\
\hline 4 & 208 & 0 & 1 & 10 & & & & 1 & & 220 \\
\hline 5 & 80 & 5 & 5 & 7 & & & 1 & 2 & & 100 \\
\hline 6 & 59 & 2 & 3 & 16 & 1 & & 1 & & & 82 \\
\hline 7 & 53 & 6 & 1 & 12 & 2 & 1 & & & & 75 \\
\hline 9 & 405 & 0 & 2 & 4 & & & & & & 411 \\
\hline 10 & 116 & 1 & 0 & 0 & & & & & & 117 \\
\hline 11 & 61 & 0 & 0 & 0 & & & & & & 61 \\
\hline 12 & 112 & 4 & 1 & 3 & & & & & & 120 \\
\hline 13 & 63 & 5 & 3 & 13 & 1 & & 5 & 3 & & 93 \\
\hline 14 & 13 & 10 & 1 & 23 & & & 1 & 3 & & 51 \\
\hline 15 & 6 & 4 & 1 & 11 & & 1 & & & & 23 \\
\hline 16 & 0 & 0 & 1 & 5 & & & & 1 & & 7 \\
\hline 17 & 31 & 0 & 1 & 21 & & & 1 & 1 & & 55 \\
\hline 18 & 12 & 0 & 0 & 9 & & 1 & & & & 22 \\
\hline 19 & 69 & 3 & 0 & 25 & & & 7 & 1 & & 105 \\
\hline 20 & 22 & 2 & 0 & 8 & & & 4 & 1 & & 37 \\
\hline 21 & 10 & 3 & 0 & 8 & & & 2 & 1 & & 24 \\
\hline 22 & 21 & 4 & 0 & 8 & & 1 & 1 & 3 & & 38 \\
\hline 23 & 3 & 0 & 0 & 12 & & & & 3 & 17 & 35 \\
\hline 24 & 11 & 5 & 4 & 44 & & & & 1 & & 65 \\
\hline 25 & 24 & 2 & 0 & 1 & & & 1 & 3 & & 31 \\
\hline 26 & 12 & 5 & 1 & 17 & & 1 & 2 & 12 & & 50 \\
\hline 27 & 28 & 3 & 1 & 5 & & & 2 & 1 & & 40 \\
\hline 28 & 66 & 2 & 2 & 4 & & & & & & 74 \\
\hline Total & 1801 & 69 & 31 & 296 & 5 & 6 & 32 & 38 & 17 & 2295 \\
\hline
\end{tabular}


Table 10. Ceramic Types by Level

\begin{tabular}{|c|c|c|c|c|c|c|c|c|c|c|}
\hline Level & 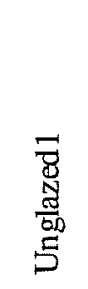 & 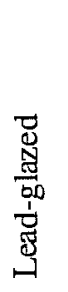 & 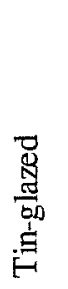 & 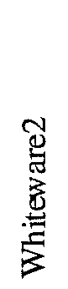 & 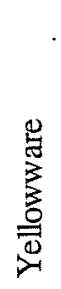 & 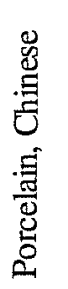 & 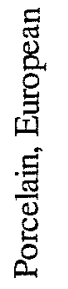 & 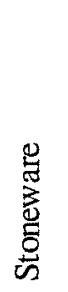 & $\frac{\text { 产 }}{\stackrel{0}{0}}$ & Totals \\
\hline 1 & 412 & 51 & 20 & 260 & 3 & 5 & 27 & 31 & & 809 \\
\hline 2 & 544 & 13 & 9 & 30 & 2 & 1 & 4 & 5 & 17 & 625 \\
\hline 3 & 673 & 4 & 1 & 4 & & & 1 & 2 & & 685 \\
\hline 4 & 126 & 1 & & 1 & & & & & & 128 \\
\hline 5 & 34 & & 1 & 0 & & & & & & 35 \\
\hline Total & 1789 & 69 & 31 & 295 & 5 & 6 & 32 & 38 & 17 & 2282 \\
\hline
\end{tabular}

${ }^{1}$ Does not include 12 specimens from Feature 2 (Unit 10 and 28 ) that were not assigned level provenience.

${ }^{2}$ Does not include 1 specimen from Feature 2 (Unit 28) that was not assigned level provenience.

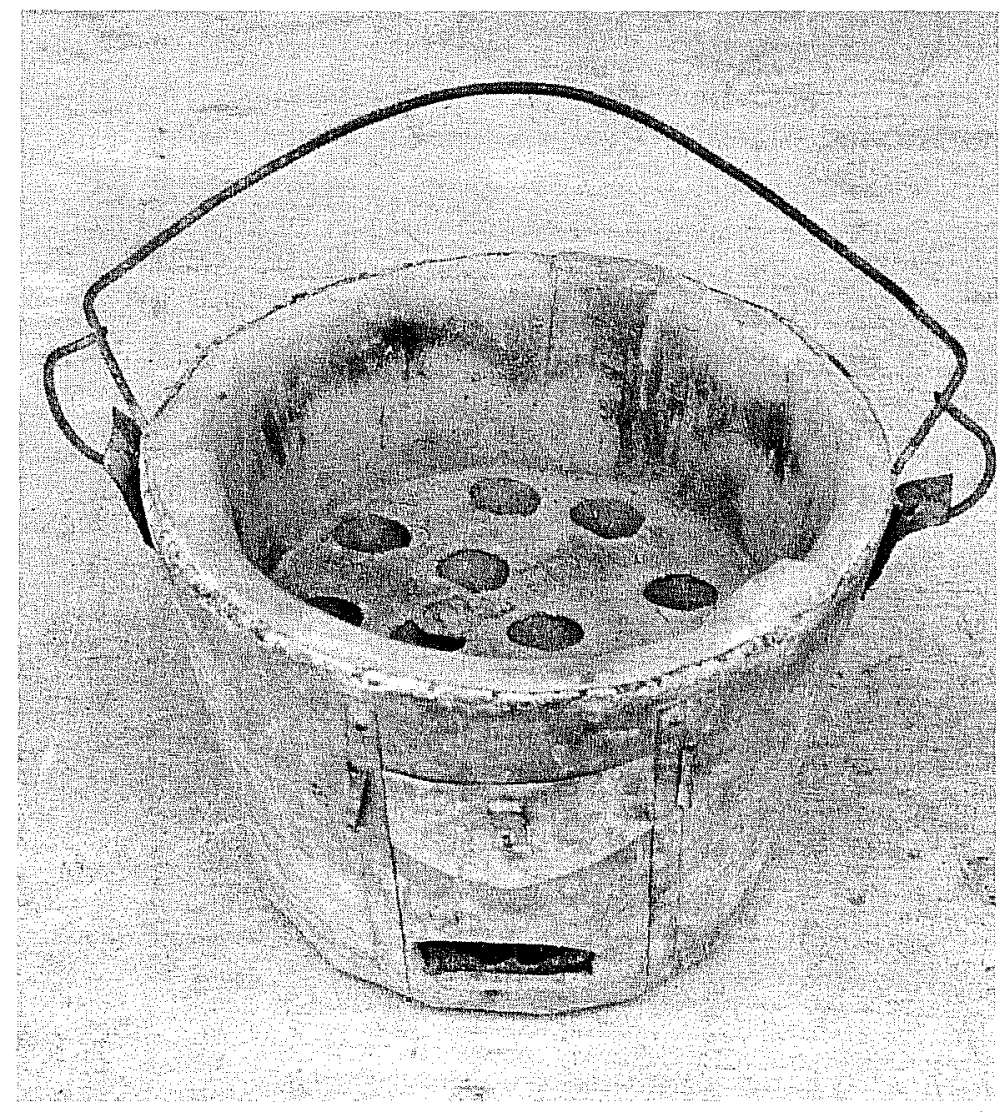

Figure 16. Historic-period brazier similar to the one recovered from Feature 1. 
Table 11. Distribution of Unglazed Ceramic Types by Unit

\begin{tabular}{|c|c|c|c|c|c|}
\hline Unit & Goliad & $\begin{array}{c}\text { Tonala } \\
\text { Burnished }\end{array}$ & $\begin{array}{c}\text { Red } \\
\text { Burnished } \\
\end{array}$ & $\begin{array}{c}\text { Other } \\
\text { Unglazed }\end{array}$ & Total \\
\hline 1 & 66 & 1 & & 1 & 68 \\
\hline 2 & 196 & & & 1 & 197 \\
\hline 3 & 48 & 2 & & 1 & 51 \\
\hline 4 & 208 & & & & 208 \\
\hline 5 & 42 & & & 38 & 80 \\
\hline 6 & 59 & & & & 59 \\
\hline 7 & 51 & & 1 & 1 & 53 \\
\hline 9 & 401 & 1 & & 3 & 405 \\
\hline 10 & 110 & & & 6 & 116 \\
\hline 11 & 60 & & & 1 & 61 \\
\hline 12 & 111 & & & 1 & 112 \\
\hline 13 & 63 & & & & 63 \\
\hline 14 & 8 & 2 & 1 & 2 & 13 \\
\hline 15 & 6 & & & & 6 \\
\hline 16 & & & & & 0 \\
\hline 17 & 31 & & & & 31 \\
\hline 18 & 12 & & & & 12 \\
\hline 19 & 68 & & & 1 & 69 \\
\hline 20 & 20 & & & 2 & 22 \\
\hline 21 & 7 & & & 3 & 10 \\
\hline 22 & 21 & & & & 21 \\
\hline 23 & 3 & & & & 3 \\
\hline 24 & 10 & 1 & & & 11 \\
\hline 25 & 23 & 1 & & & 24 \\
\hline 26 & 12 & & & & 12 \\
\hline 27 & 27 & & & 1 & 28 \\
\hline 28 & 64 & & & 2 & 66 \\
\hline Total & 1727 & 8 & 2 & 64 & 1801 \\
\hline
\end{tabular}

this type across the southwest to California (Barnes 1980:102; Gerald 1968:54). These excavations recovered 13 (20 percent of lead-glazed) Galera sherds.

A lead-glazed pottery type consisting of a creamy beige body decorated with brown linear designs and covered with a clear glaze (Fox 1974:58) is found occasionally on San Antonio River sites. This may be a late eighteenth century type which has carried over into the present, as bowls that resemble this ware are still being made in Mexico today. One (1 percent of leadglazed) yellow with brown sherd was found in this collection.
Two ( 3 percent of lead glazed) sherds are fragments of heavy olive jars, used originally for shipping liquids such as olive oil and wine to the New World from Spain (Goggin 1968:253). Such sherds usually have a green glaze on one face and a white slip on the other. Finally, the two remaining lead glazed sherds could not be identified.

\section{Tin-glazed Wares}

Tin-glazed wares are earthenwares with a lead glaze to which tin has been added to create a cream or white background for colored enamel decoration. The 
Table 12. Distribution of Lead-glazed Ceramic Types by Unit

\begin{tabular}{|c|c|c|c|c|c|c|}
\hline Unit & $\begin{array}{l}\text { Sandy } \\
\text { Paste }\end{array}$ & Galera & $\begin{array}{c}\text { Yellow w: } \\
\text { Brown }\end{array}$ & Olive Jar & Other & Total \\
\hline 1 & 2 & & & & & 2 \\
\hline 2 & 1 & & & & & 1 \\
\hline 3 & & & & & & 0 \\
\hline 4 & & & & & & 0 \\
\hline 5 & 4 & & 1 & & & 5 \\
\hline 6 & 2 & & & & & 2 \\
\hline 7 & 3 & 2 & & & 1 & 6 \\
\hline 9 & & & & & & 0 \\
\hline 10 & 1 & & & & & 1 \\
\hline 11 & & & & & & 0 \\
\hline 12 & 3 & & & & 1 & 4 \\
\hline 13 & 5 & & & & & 5 \\
\hline 14 & 9 & 1 & & & & 10 \\
\hline 15 & 4 & & & & & 4 \\
\hline 16 & & & & & & 0 \\
\hline 17 & & & & & & 0 \\
\hline 18 & & & & & & 0 \\
\hline 19 & & 3 & & & & 3 \\
\hline 20 & 2 & & & & & 2 \\
\hline 21 & 3 & & & & & 3 \\
\hline 22 & 4 & & & & & 4 \\
\hline 23 & & & & & & 0 \\
\hline 24 & 3 & 2 & & & & 5 \\
\hline 25 & 1 & & & 1 & & 2 \\
\hline 26 & 2 & 2 & & 1 & & 5 \\
\hline 27 & 1 & 2 & & & & 3 \\
\hline 28 & 1 & 1 & & & & 2 \\
\hline Total & 51 & 13 & 1 & 2 & 2 & 69 \\
\hline
\end{tabular}

decorative patterns underwent frequent changes through time, making this ceramic type useful for dating purposes. For that reason, they are dealt with here in more detail than other ceramic types. A total of 31 (1.3 percent of total) tin glazed specimens were identified in the sample (Table 13).

Undecorated sherds can represent totally undecorated vessels, which were made throughout the eighteenth century (Lister and Lister 1974:30). They also can be merely undecorated sections of vessels bearing painted designs. Six (21 percent of tin-glazed) undecorated sherds were found.
San Agustín Blue-on-white is a pattern consisting of floral designs in two shades of blue. Plates with this pattern have large pale blue loops on the underside. The generally accepted dates for this pattern are 1700 to 1730 (Goggin 1968:189), although some slightly later sites appear to contain a few sherds. Identification of this type is difficult on small sherds. Although there were a number of sherds suspected to bear this pattern, none were large enough to be sure and all have been included here in a generic blue-on-white category.

Puebla Blue-on-white is a simple design consisting of blue rim bands from which are suspended a row of single blue petals alternating with a whole blue flower. 
Table 13. Distribution of Tin-glazed Ceramic Types by Unit

\begin{tabular}{|c|c|c|c|c|c|c|c|c|c|}
\hline Unit & 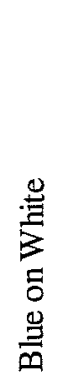 & 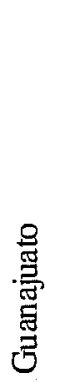 & 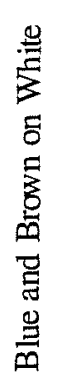 & 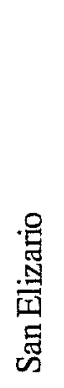 & 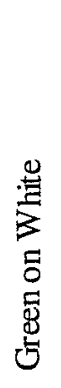 & 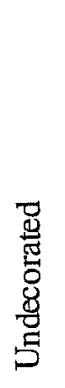 & 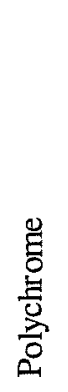 & 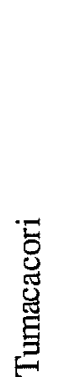 & Total \\
\hline 1 & 1 & & & & & & 1 & & 2 \\
\hline 2 & & & & & & & & & 0 \\
\hline 3 & & & & & & & & 1 & 1 \\
\hline 4 & & & 1 & & & & & & 1 \\
\hline 5 & 4 & & & & & 1 & & & 5 \\
\hline 6 & & 3 & & & & & & & 3 \\
\hline 7 & & & & 1 & & & & & 1 \\
\hline 9 & 1 & & & & & 1 & & & 2 \\
\hline 10 & & & & & & & & & 0 \\
\hline 11 & & & & & & & & & 0 \\
\hline 12 & & & & & & 1 & & & 1 \\
\hline 13 & 1 & 1 & & & & 1 & & & 3 \\
\hline 14 & & & & & & 1 & & & 1 \\
\hline 15 & 1 & & & & & & & & 1 \\
\hline 16 & & & & & & & 1 & & 1 \\
\hline 17 & 1 & & & & & & & & 1 \\
\hline 18 & & & & & & & & & 0 \\
\hline 19 & & & & & & & & & 0 \\
\hline 20 & & & & & & & & & 0 \\
\hline 21 & & & & & & & & & 0 \\
\hline 22 & & & & & & & & & 0 \\
\hline 23 & & & & & & & & & 0 \\
\hline 24 & 3 & & & & & 1 & & & 4 \\
\hline 25 & & & & & & & & & 0 \\
\hline 26 & & 1 & & & & & & & 1 \\
\hline 27 & 1 & & & & & & & & 1 \\
\hline 28 & & 1 & & & 1 & & & & 2 \\
\hline Total & 13 & 6 & 1 & 1 & 1 & 6 & 2 & 1 & 31 \\
\hline
\end{tabular}

Floral arrangements or a bird or deer form the central design. A large portion of each of these vessels is undecorated, probably accounting for many of the undecorated sherds recovered. No blue-on-white sherds in this collection could confidently be placed in this category. Since they are really too small to differentiate patterns, we have grouped all otherwise unidentifiable blue on white sherds within one allinclusive category of blue-on-white, realizing that this may include some San Agustin and perhaps other as yet unidentified patterns as well. Thirteen sherds (38 percent of tin-glazed) comprise this category. 
San Elizario, a subtype of Puebla Blue-on-white, is a design named by Gerald (1968:45) and dated by him to $1750-1800$. This consists of the same blue on white design with suspended petals and flowers, but these have dark brown to black lines and accents. One (3 percent of tin-glazed) sherd of this type was recovered.

One sherd (three percent of tin-glazed) of majolica has a blue glaze on both sides, which securely identifies it as Tumacacori, a polychrome pattern with blue background that dates between 1780 and 1860 (Barnes and May 1972:12).

One (three percent of tin-glazed) very small sherd has olive green touches on a white background. There is not enough there to allow recognition of a pattern. The green is not consistent with the colors used in the late-eighteenth-century polychromes.

Blue and Brown-on-white, a later eighteenth-century type, consists of small blue and brown floral decorations on a thin body, leaving large areas undecorated. This type was first recorded at Mission San Juan Capistrano by Schuetz (1969:57) and has since been noted at most other San Antonio mission sites. The delicacy of the design suggests possible British or French influence. One (three percent of tinglazed) sherd was found during these excavations.

A new color combination of rust, green, and brown/ black on a greenish cream background began to appear after ca. 1810 (Lister and Lister 1974:Figure 12). Called Guanajuato for the area where it was made, this ware appears on all the San Antonio mission sites and on early-nineteenth-century sites in Laredo (Folan et al. 1986; Clark and Juarez 1986). Six (21 percent of tin glazed) specimens of this type were identified.

\section{Whitewares}

The presence of whitewares is generally an indicator of nineteenth century occupation on San Antonio sites. British-made white bodied wares began to appear in this area in the early 1830 s. It was not until after the Civil War that American potteries began to be represented on San Antonio sites, at which time most of the whitewares were Ironstone or its equivalent. A total of 296 whiteware sherds was identified in the collection (Table 9). They are categorized into nine groups (Table 14).

Undecorated sherds of whiteware can represent portions of otherwise decorated vessels or may come from wholly white vessels. It is nearly impossible in most cases to determine the difference. Of the 215 undecorated sherds, perhaps 50 percent are from plain white Ironstone plates, the rest are probably from earlier, decorated vessels.

Decoration on whiteware can take many forms. The 81 decorated sherds represent sponged $(n=13)$, edge decorated $(n=2)$, transfer $(n=12)$, banded slip $(n=8)$, hand painted $(n=31)$, decal decorated $(n=12)$, and plain colored glaze $(n=1)$. The first five probably date to the early-nineteenth century, the last two perhaps the late-nineteenth to early-twentieth century. The two remaining specimens could not be categorizes into either of these types, and are listed as other decorated.

\section{Yellowware}

A total of five (.2 percent of total) yellowware sherds were identified in the collection (Table 9). The British occasionally produced yellow-bodied kitchen wares decorated in the same manner as their whitewares. Two such sherds are in this collection. In the late nineteenth century and early twentieth century, heavier yellowware was made in the United States. It was used for kitchen and utility vessels such as mixing bowls and pie plates available to housewives through mail order catalogs and hardware stores (Roycraft and Roycraft 1975:Plate 16). Three American yellowware sherds were recovered. The two types of yellowware are easily separated because of the refinement in potting and decoration on the British ware.

\section{Chinese Porcelain}

Six sherds (.3 percent) are grouped in this category (Table 9). Cups and bowls of porcelain arrived at Acapulco aboard the Manila galleons in the earlyeighteenth century. Mexican buyers transported them to Mexico City where they were purchased by 
Table 14. Distribution of Whiteware Types by Unit

\begin{tabular}{|c|c|c|c|c|c|c|c|c|c|c|}
\hline Unit & 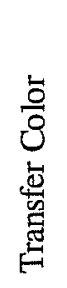 & 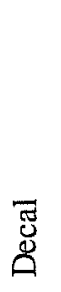 & 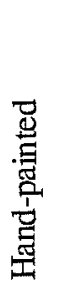 & $\begin{array}{l}\text { 品 } \\
\bar{\Xi} \\
\text { 㔛 }\end{array}$ & 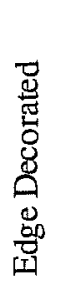 & $\begin{array}{l}\text { 若 } \\
\text { : } \\
\text { ص̃ }\end{array}$ & 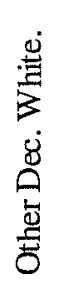 & 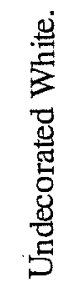 & $\begin{array}{l}\overrightarrow{0} \\
\frac{0}{0} \\
0 \\
\frac{3}{0} \\
\frac{\pi}{2}\end{array}$ & Total \\
\hline 1 & 1 & & 1 & & & & & 14 & & 16 \\
\hline 2 & & 4 & & & & & & 1 & & 5 \\
\hline 3 & & & 1 & & & 1 & & 7 & & 9 \\
\hline 4 & 1 & 1 & & 2 & & & & 6 & & 10 \\
\hline 5 & & & 4 & & & & & 3 & & 7 \\
\hline 6 & & & 6 & 1 & & & & 9 & & 16 \\
\hline 7 & & 3 & & & & & & 9 & & 12 \\
\hline 9 & & & 1 & & & & & 3 & & 4 \\
\hline 10 & & & & & & & & & & 0 \\
\hline 11 & & & & & & & & & & 0 \\
\hline 12 & & & & & & & & 3 & & 3 \\
\hline 13 & 1 & & & 1 & & & & 11 & & 13 \\
\hline 14 & & 1 & 4 & 1 & 1 & & & 16 & & 23 \\
\hline 15 & & & & & & & & 11 & & 11 \\
\hline 16 & & & 2 & 2 & & & & 1 & & 5 \\
\hline 17 & & & 7 & 5 & 1 & 2 & & 6 & & 21 \\
\hline 18 & 1 & & & 1 & & 1 & & 6 & & 9 \\
\hline 19 & 2 & 2 & 1 & & & 2 & 1 & 17 & & 25 \\
\hline 20 & & & & & & 1 & & 7 & & 8 \\
\hline 21 & 1 & & 1 & & & & 1 & 4 & 1 & 8 \\
\hline 22 & & & & & & & & 8 & & 8 \\
\hline 23 & & & & & & & & 12 & & 12 \\
\hline 24 & 3 & 1 & 1 & & & & & 39 & & 44 \\
\hline 25 & & & & & & & & 1 & & 1 \\
\hline 26 & 1 & & 1 & & & & & 15 & & 17 \\
\hline 27 & & & & & & 1 & & 4 & & 5 \\
\hline 28 & 1 & & 1 & & & & & 2 & & 4 \\
\hline Total & 12 & 12 & 31 & 13 & 2 & 8 & 2 & 215 & 1 & 296 \\
\hline
\end{tabular}


Franciscan conductors of supplies and hauled to the frontier missions. Sherds of these vessels are found in every mission on the frontier.

\section{European and American Porcelain}

There are 32 (1.4 percent of total) European and American porcelain sherds in this collection (Table 9). This type of porcelain is a thin, vitrified, translucent ceramic. Some of the sherds in this collection probably originated in Europe, where most of the porcelain was made until late in the nineteenth century. Families often had just a few pieces such as tea cups and saucers or dessert plates which they saved for special occasions. By the late-nineteenth century American companies were turning out inexpensive porcelains which could be acquired by any household. In general, the inexpensive porcelain is thinner and breaks into smaller sherds. No attempt has been made to separate the European and American made types.

\section{Stoneware}

Thirty-eight (1.7 percent of total) stoneware sherds were recovered (Table 9). Stoneware is a dense, hard ceramic with a white, tan or gray paste. Vessels made of this ware were used for food preparation and storage. Bexar County potters made these wares for local consumption from the last quarter of the nineteenth century into the 1920s (Fox 1998).

\section{Unidentified Type}

Seventeen ( .7 percent of total) sherds recovered from the second level of Unit 23 are of a high-fired red body glazed on the outside with a clear glaze and on the inside with a white opaque glaze. Occasional sherds of this type have been found on early 20th century sites in the San Antonio area and vessels of this appearance can be found in local antique and junk shops. They appear to be kitchen wares for oven use. So far we have no information on their place of manufacture.

\section{Glass, Metal, and Miscellaneous Artifacts}

\section{Household Items}

Glass containers

A total of 126 fragments of glass containers of various colors was identified. The glass found on colonial sites in San Antonio is nearly always limited to olive green wine bottle glass. In this collection, only one fragment of an olive green wine bottle base was found in the third level of Unit 4. The fact that so much clear and colored glass was found in the upper levels of all units confirms that these deposits represent post-colonial occupation, or a mixture of that occupation with an earlier one.

One complete clear glass prescription bottle was found in Feature 2 of Unit 28. Its general configuration dates it to the post-1903 period. The fact that it was closed with a cork rather than a screw top probably indicates it was first used before the late 1920s.

\section{Tableware}

Several tableware fragments were recovered. The handle to a table fork was found in Level 1 of Unit 14. The handle and bowl of a tablespoon came from Level 1 of Unit 1 . A badly bent but whole silver plated table fork was found in Level 1 of Unit 7.

\section{Personal Items}

\section{Clothing}

Thirteen buttons were recovered during this project. Dimensions and descriptions are given in Table 15.

Two buckles were recovered from the excavations. A small ( 1 by 1.5 inches) belt buckle came from Unit 14 , Level 1, and an overall strap buckle came from Unit 26, Level 2. Also, four safety pins of various sizes were found, all from Level 1 in Units 7, 10, 19, and 22. 
Table 15. Button Data

\begin{tabular}{|l|l|c|c|c|l|}
\hline \multirow{2}{*}{ Type } & \multirow{2}{*}{ Material } & \multirow{2}{*}{$\begin{array}{c}\text { Diameter } \\
\text { (inches) }\end{array}$} & \multicolumn{2}{c|}{ Provenience } & \multirow{2}{*}{ Notes } \\
\cline { 4 - 6 } 1-hole & bone & $5 / 8$ & 28 & 1 & \\
\hline 2-hole & shell & $3 / 8$ & 19 & 1 & \\
\hline 2-hole & shell & $5 / 16$ & 15 & 1 & \\
\hline 4-hole & ceramic & $3 / 8$ & 15 & 1 & \\
\hline 4-hole & ceramic & $3 / 8$ & 17 & 1 & \\
\hline 4-hole & ceramic & $3 / 8$ & 7 & 1 & \\
\hline 4-hole & ceramic & $1 / 2$ & 26 & 2 & piecrust design \\
\hline 4-hole & metal & $1 / 2$ & 2 & 1 & \\
\hline 4-hole & metal & $1 / 2$ & 7 & 1 & \\
\hline brazed loop & metal & $1 / 2$ & 22 & 1 & \\
\hline hand snap & metal & $5 / 8$ & 26 & 2 & \\
\hline soldered loop & metal & $1-1 / 8$ & 7 & 2 & Modern U.S.uniform \\
\hline compound & metal & $3 / 4$ & 14 & 1 & \\
\hline
\end{tabular}

Fragments of shoe leather from Unit 13 Level 1 contained six eyes for shoe laces, and a smaller shoe lace eye came from Unit 12, Level 2. A fragment of a rubber shoe heel was recovered from Level 1 of Unit 12.

Jewelry

Several glass beads came from the excavations. $\mathrm{A} / \frac{1}{4}$ inch clear glass bead was recovered from Unit 28 , Level 2. A faceted white glass bead averaging $3 / 8$ of an inch in diameter came from Unit 3, Level 2. Half of a $3 / 8$-inch clear glass bead came from Level 3 in the same unit. A small, $5 / 16$-inch across gold metal heartshaped pendant was found in Level 1 of Unit 14.

\section{Coins}

Three coins were recovered. the oldest was a 1918 buffalo nickel from Level 1 of Unit 12. Two others from Level 1 of Unit 3 were a Jefferson nickel dated
1966 and a 1969 Lincoln penny. From Level 2 of Unit 12 came a white metal token marked on one side, "GOOD FOR 10 IN TRADE," and on the other, "1909." These tokens were in popular use around the turn of the century.

\section{Amusement Objects}

Fragments of slate from small, wood-framed slates used by children in school and by adults as well into the late-nineteenth century, came from Units 18 and 22. Level 1, and Unit 26, Level 2. Probably the more recent writing instrument, the lead pencil, is represented in this collection by pencil lead fragments and metal eraser attachments for pencils from Unit 2 Level 2 and Unit 10, Level 1.

Reflecting the presence of children in the area, we recovered four unglazed clay marbles from Level 1 in Units 5, 17, and 20. Children could easily make these marbles by rolling clay between their hands and baking 
the resulting marbles in the family oven. The marbles recovered during this project were a bit too regularly round to have been hand made and probably were purchased. Machine-made marbles were available starting about 1884 and were still being listed in the Sears catalog as late as 1928 (Zapata 1997:1-8). Also found was a red rubber ball 1.25 inches in diameter.

\section{Construction-related Materials}

Hardware

A total of 266 artifacts are categorized as hardware. Items of interest among these are a keyhole escutcheon which came from Level 1 of Unit 25, an early metal and porcelain light socket found in Level 1 of Unit 7 , a porcelain fragment of another from Level 1 of Unit 5 , and a porcelain insulator in Level 2 of Unit 9. These represent the time period soon after electricity reached this part of San Antonio. A thin metal pipe 1/4 inch in diameter with a combination nut and screw at one end for attachment appears to be part of a plumbing fixture or a piece of machinery.

Nails

All the nails recovered during this project are wire nails, which did not reach the San Antonio area until the very end of the nineteenth century and the first of the twentieth century. No hand-forged Colonial nails were found. The nails probably represent either the period of the construction of the small frame houses that replaced the stone Indian Quarters, or the reconstruction of the mission by Harvey Smith.

\section{Building Materials}

Two hundred ninety-four artifacts are included in this category. Fragments of roofing tar were found in many units in all levels. Clay tile fragments were found in Level 1 of Units 1, 5, 6, and 9. One white ceramic tile $3 / 4$ inch square and $3 / 8$ inch thick came from Level 1 in Unit 19. Such tiles were popularly used on bathroom floors in the 1920s. Fragments of modern red brick were found in most units and all levels. In addition, in
Units 7 and 26 at Level 1, Colonial brick fragments were found. All the missions were apparently making and using this type of brick which is readily separated from late-nineteenth to early-twentieth century brick by its lighter tan color, highly visible white inclusions, and shape. Mission-made bricks were approximately $7 / 8-1$ inch thick, and rectangular in shape.

Fragments of window glass were found in Level 2 in a number of the units. The pieces probably have little analytical importance as far as the location of windows in previous structures is concerned.

\section{Metal}

A total of 1,170 metal fragments and identifiable objects was recovered (Table 8 ).

Metal Fragments

A total of 1,078 unidentified metal fragments was recovered. Unidentifiable thin rusted metal fragments were found in nearly every level of every unit. These tend to represent disintegrated tin cans and other thin iron objects. For the most part, they are customarily found in nineteenth- to early-twentieth-century occupation sites, and in this case may indicate a great deal of disturbance of the deposits.

\section{Metal Objects}

Ninety-two identifiable metal objects were recovered. This category contains numerous bottle caps and screw tops for glass bottles and jars, recovered mostly in the upper two levels of the site. Bottle caps found at deeper levels probably represent the burrows of ground squirrels which were numerous at all the missions as late as the 1960s and were particularly fond of fresh, shiny bottle caps (Schuetz 1970:15).

One can key was found in Unit 26, Level 1. A clothespin spring came from the first level in Unit 5. Such common household items are usually found on occupation sites of this period. 


\section{Lithic Artifacts}

Two hundred twenty-five chipped lithic artifacts were recovered (Table 8). They are categorized into the following functional groups: 10 arrow points and arrow point blanks, two gun flints, three scrapers, and one knife. Function was partially determined by lowpowered (80x) micro-wear analysis. Five unifacially flaked artifacts and one bifacially flaked item could not be grouped into functional categories. They are classified as indeterminate unifacial and bifacial artifacts, respectively. Three flake cores also were recovered, in addition to 194 pieces of unmodified lithic debitage. All artifacts are of fine-grained chert, most likely obtained from the nearby San Antonio River.

\section{Arrow Points}

Ten arrow points and fragments were identified in the collection. Of these, two compllete and one proximal arrow point fragment are classi ied as Guerrero points (Figure 17). An additional roximal fragment is classified as a Guerrero prefor a. Guerrero points are commonly associated with nission occupations (Turner and Hester 1993). The specimens are characterized by triangular to 3 anceolate outlines and slightly to moderately concav 2 bases. Flake blank ventral surfaces could be identi iied on two of the four, the others we fully bifacially flaked. Both complete specimens exhibit blade rejuve nation (Table 16). The

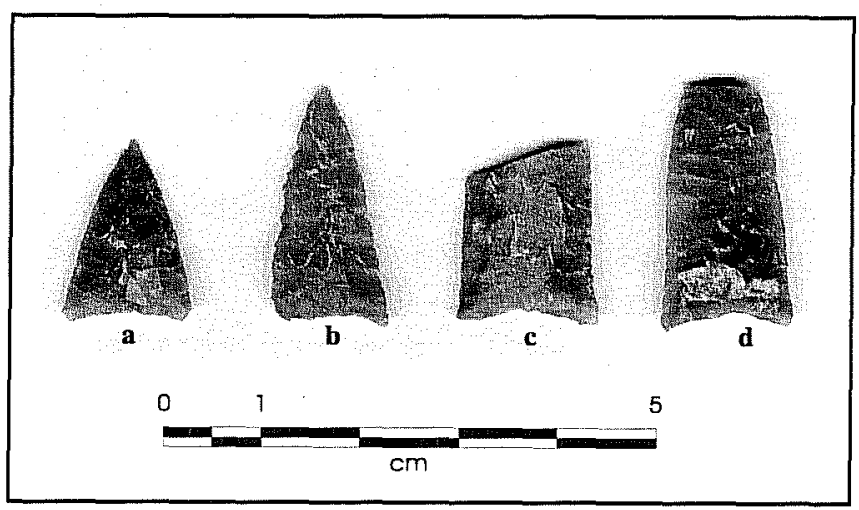

Figure 17. Guerrero arrow points from Mission San Jose. proximal fragment was broken in use near the distal end. The Guerrero preform exhibits a large portion of the flake blank ventral surface and has been broken in manufacture in the vicinity of the neck.

In addition to these four specimens, one use-broken arrow point distal fragment appears to have been a finished specimen. Although it is classified as untypable, it is likely that it represents an additional Guerrero specimen. Finally, five other artifacts are classified as arrow point blanks. All are tertiary flake blanks. Three of these were broken in manufacture. Break cause could not be identified on the other two.

\section{Gun Flints}

Two gunflints (Figure 18) made of local-origin finegrained chert were recovered. The most formal of the gunflint is a $4 \mathrm{~mm}$ thick rectangular specimen measuring $26 \mathrm{~mm}$ in length and $20 \mathrm{~mm}$ in width (Figure 18a, Table 16 ). It appears to have been made on a broad tertiary flake blank or perhaps a tertiary blade. The blank was bifacially shaped with retouch flakes penetrating only $5-10 \mathrm{~mm}$ from the margins. The presence of rounded and polished surfaces on both faces and along all four margins seems to derive from movement of the flint inside the cushion and between the cap and the hammer. Use-wear, in the form of unifacially crushed edges is present on all four edges suggesting that the specimen was reoriented an number of times. However, the presence of only unifacial wear

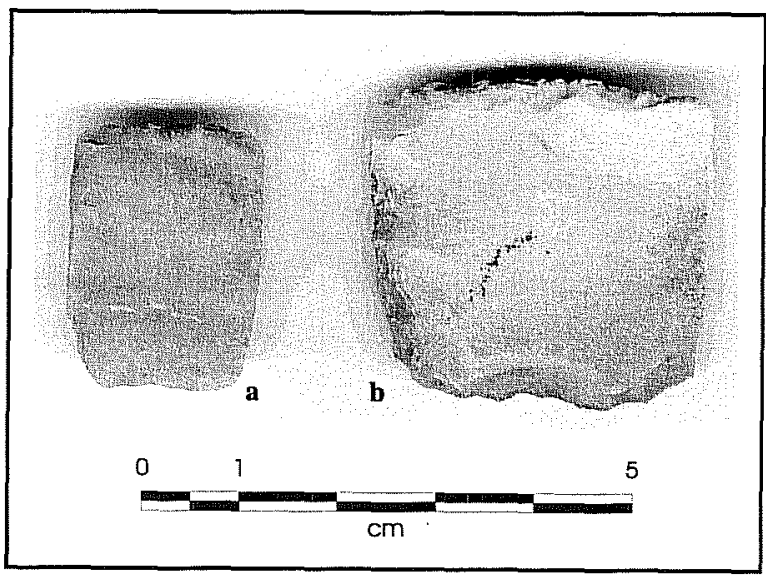

Figure 18. Gunflints from Mission San Jose. 
Table 16. Lithic Artifact Characteristics by Category

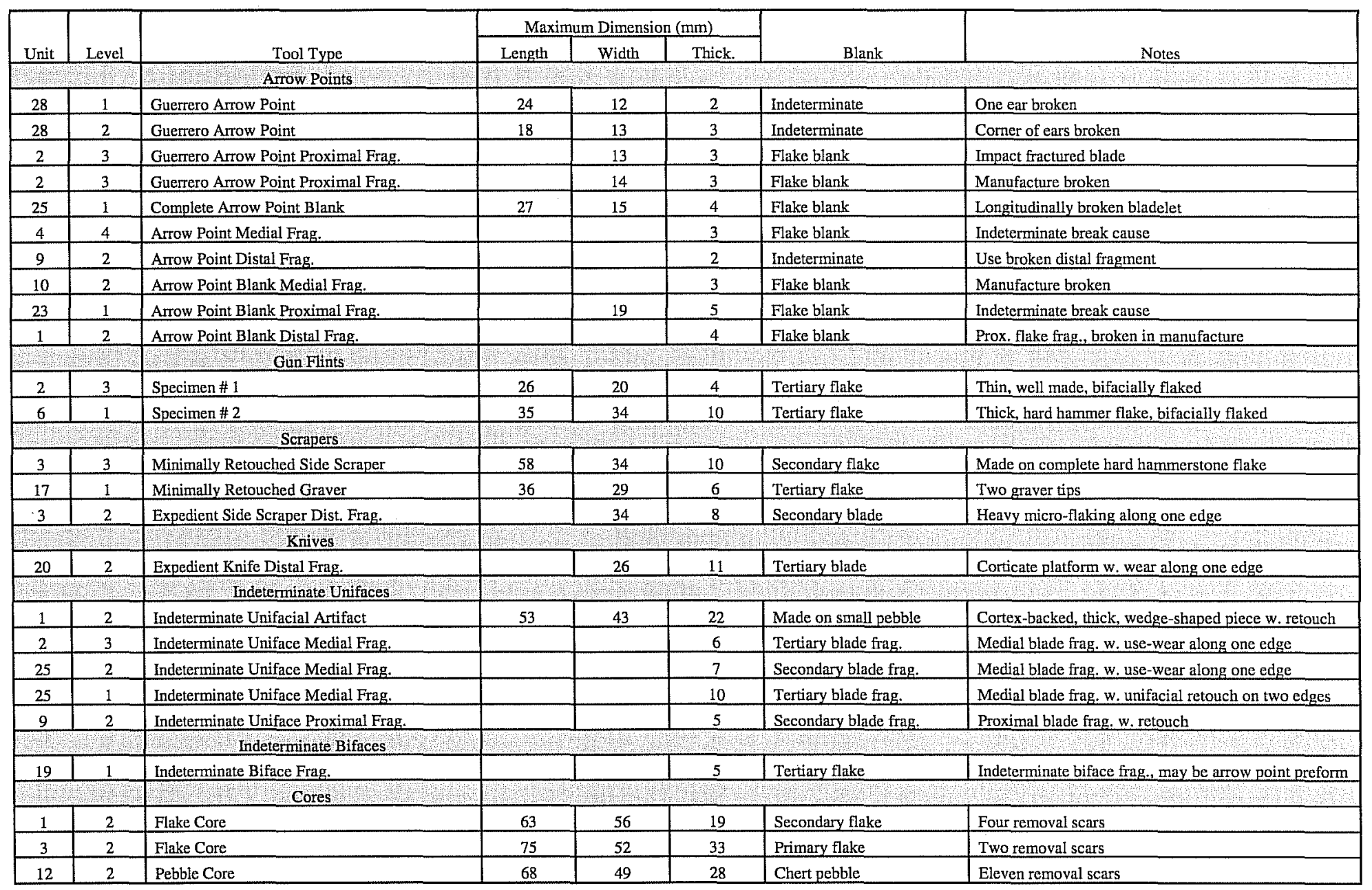


suggests that the flint had not been turned over. The second gunflint is a $10-\mathrm{mm}$-thick roughly rectangular (35 x $34 \mathrm{~mm}$ ) specimen (Figure 18b). It was made on the proximal portion of a flake blank. The two sides of the specimen adjacent the bulb of percussion have been bifacially retouched, the opposite two sides are unifacially retouched on alternate faces. The two faces of one of the two bifacially flaked edges exhibits rounded and polished facets derived from the flint having been held between the cap and the hammer. Short (less than $5 \mathrm{~mm}$ ) step fractured use-wear scars are present along three of the sides including the two bifacially flaked margins.

\section{Scrapers}

Two unifacial scrapers have been recovered from the San José excavations (Table 16). Based on the location of the working edge they are both classified as side scrapers. Based on the degree of retouch on their working edges, one of the two specimens is minimally retouched while the other is an expedient scraper. The minimally retouched specimen is a complete secondary hammerstone flake with retouch and usepolish along one edge. The expedient scraper fragment is the distal end of a broad secondary blade. One of its margins exhibits small ( $2 \mathrm{~mm}$ ) flakes and very slight polish derived from use.

\section{Graver}

A single graver made on a biface thinning flake was recognized in the collection. It has two graving tips along one edge. The edges were alternately flaked to produce the working tips.

\section{Knife}

A single proximal blade fragment exhibits a minutely scalloped acute working edge reminiscent of use-wear derived from cutting or sawing (Table 16). Since it has not been retouched prior to use it is classified as an expedient tool. The specimen is a hard hammerstone blade fragment with a corticate platform.

\section{Indeterminate Unifaces}

One unifacially retouched flake and four blade fragments are included in this category. These specimens represent items that could not be classified into functional tool categories due to their fragmentary nature or lack of use-wear. The complete specimen is a small coarse-grained chert pebble that has been unifacially flaked into a wedge shape. It has a planoconvex cross section and is entirely corticate on one face and at one end (Table 16). The remaining four specimens are small unifacially retouched medial $(n=3)$ and proximal $(n=1)$ blade fragments. It was not possible to determine whether they represented end, side, or combination end/side scrapers. Two of the fragments are minimally retouched, two remaining two exhibit only use-related micro-flaking. With the exception of thickness, no other dimensions were recorded on these specimens.

\section{Indeterminate Biface}

A single bifacially flaked tertiary flake fragment is included in this group. It appears to be the medial fragment of a biface reduction flake. Although it might have been intended as an arrow point, it is too fragmentary allow precise interpretation (Table 16). It appears to represent a very early reduction stage arrow point blank discarded prior to completion. The cause of the break present on the broad proximal portion of the flake cannot be determined.

\section{Unmodified Debitage}

One hundred ninety-four unmodified debitage pieces were recovered from excavation. The breakdown of cortex categories among these specimens indicates that tertiary flakes constitute a slightly higher percentage than secondary flakes (Figure 19). Primary flakes are a small portion of the collection, while tertiary debitage dominates. In general, the distribution of cortex categories is similar to that obtained during the 1997 work at the mission (Tomka and Fox 1998). The proportion of tertiary debitage encountered in the present assemblage is slightly higher than that noted in the 1997 collection. The distribution of debitage 
by size classes indicates that $11-20$ and $21-30 \mathrm{~mm}$ specimens dominate (Figure 20). The smallest size class (1-10 $\mathrm{mm}$ ) may be under-represented primarily because of the $1 / 4$ inch hardware cloth used in screening the bulk of the matrix. The size class distributions are again similar to those from the 1997 work (Tomka and Fox 1997) and indicate a gradual decrease in the percentage of specimens in the larger size classes with increased size. The pattern is even more gradual than in the previous case, and may reflect the effect of increased sample size. The distribution of platform facet counts indicates that single faceted flakes are the most common among the platform-bearing flakes (complete and proximal fragments, Figure 21). Importantly, corticate platforms are the second most common type, further indicating the relative scarcity of flakes with highly prepared platforms. Platform-bearing flakes with two and three or more facets represent a relatively small proportion of the collection. This pattern stands in strong contrast to debitage collections dominated by bifacial reduction, where multifaceted striking platforms greatly out number corticate and single faceted specimens (Tomka 1989). Finally, the breakdown of the debitage collection in terms of flake type indicates that core/platform preparation flakes constitute the largest proportion of the sample (Figure 22). Given that, as mentioned before, a large proportion of the platform-bearing flakes are single faceted or corticate, and many of the specimens have bladelet-like morphologies, it is likely that most of these flakes derive from the preparation of uni- or bidirectional cores rather bifacial core reductions (e.g., bifaces). Blades and angular debris constitute the second largest

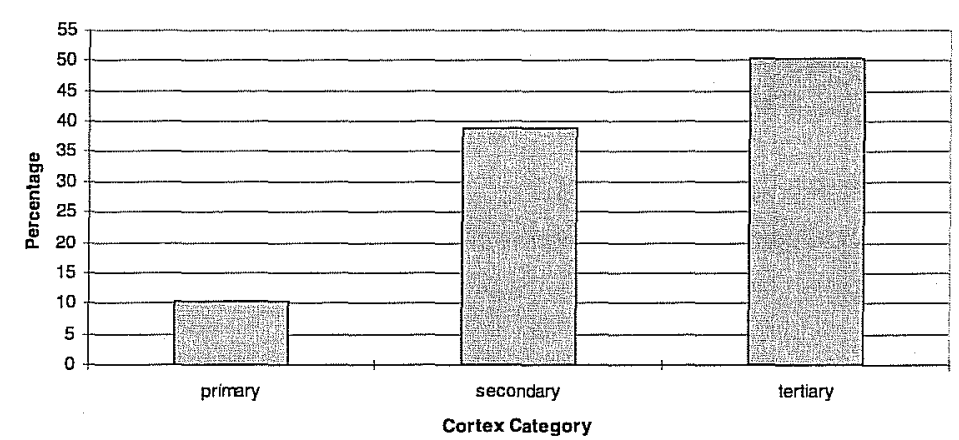

Figure 19. Distribution of debitage cortex categories.

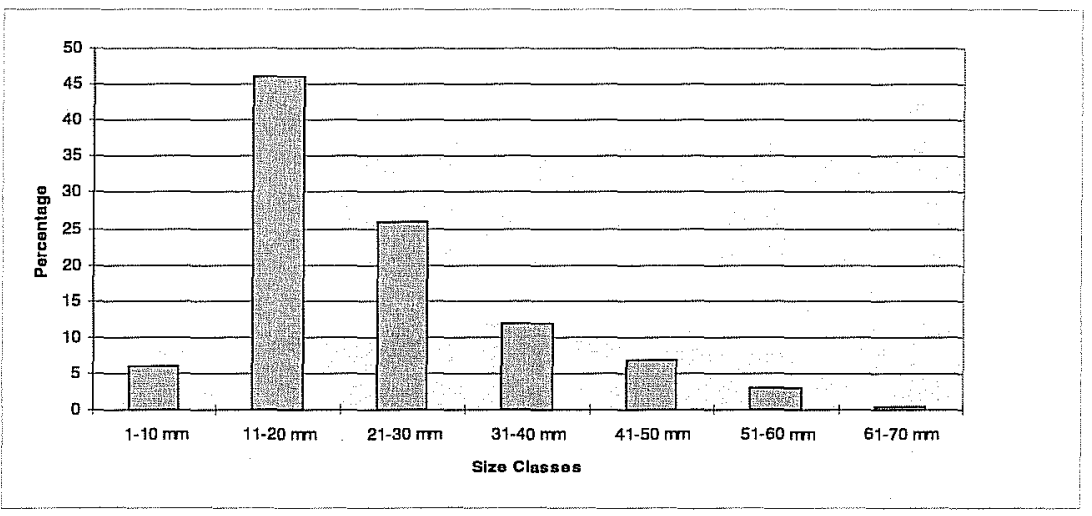

Figure 20. Distribution of debitage by size.

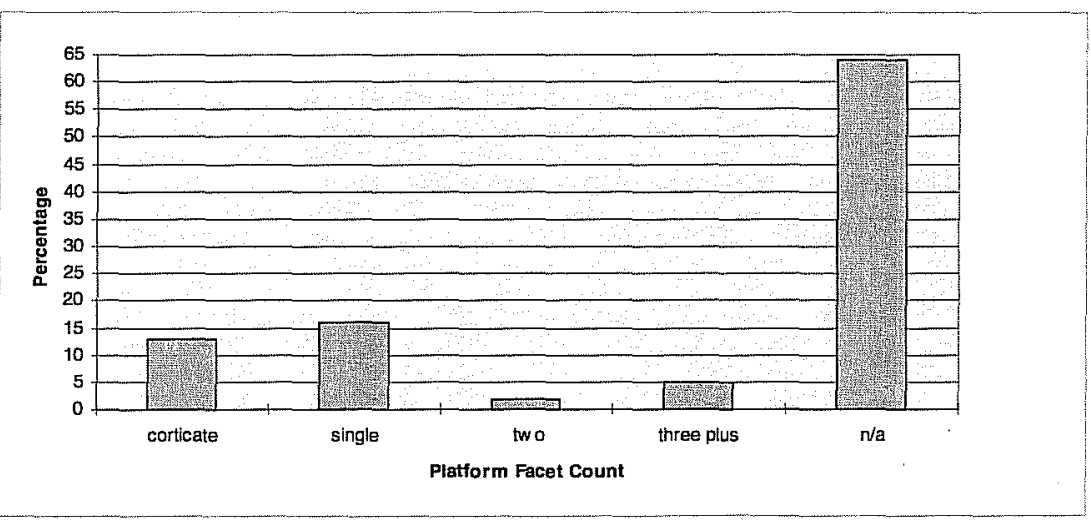

Figure 21. Distribution of platform-bearing flakes by facet count.

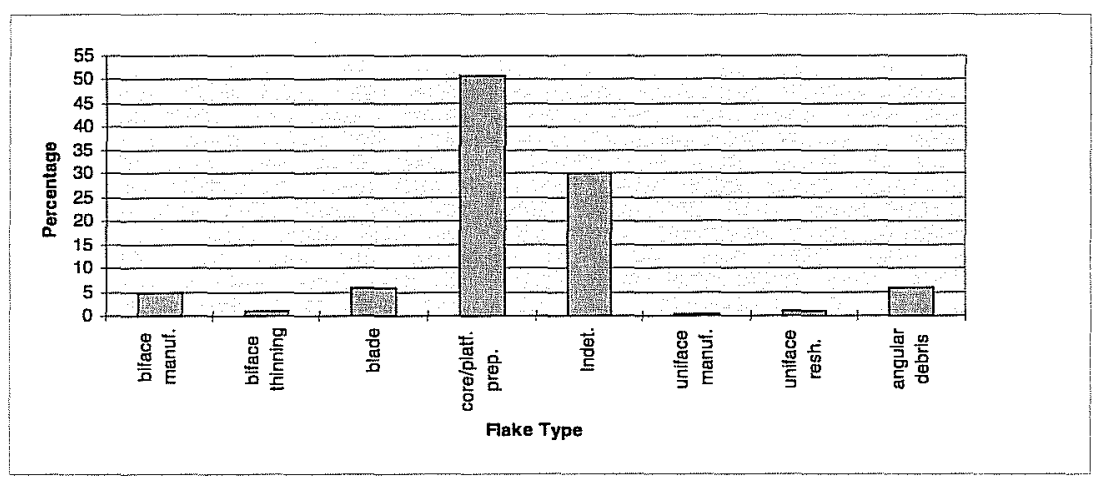

Figure 22. Distribution of debitage by flake type. 
percentage of the debitage, excluding indeterminate flakes. Flakes identified as the products of other reduction strategies (e.g., biface manufacture, thinning, and uniface manufacture and resharpening), represent a very small proportion of the collection. The scarcity of biface flakes corresponds to the relative emphasis on uni- and perhaps bidirectional blade production at the mission (see also Fox 1979:37; Hester 1982). The scarcity of debitage derived from uniface manufacture and resharpening is somewhat surprising especially given the apparent emphasis on blade production. It is possible that some of the blades were used in the manufacture of tools forms other than unifacial scrapers. On the other hand, it is also likely that the debitage resulting from the making of minimally retouched scrapers and the use of expedient scrapers would be relatively small and would not be recovered in $1 / 4$-inch screening.

Overall, the lithic technology evident in the San Jose lithic artifacts indicates local or nearby raw material procurement, a tool kit composed primarily of expedient tool forms (e.g., scrapers), and the continued manufacture of stone arrow points even though metal points and guns have already been adopted. Raw material reduction strategies are dominated by unidirectional core reduction to produce blades and probably gunflint blanks. Bifacial reduction appears to be employed in arrow point manufacture and the shaping of some gunflint blanks.
Overall, the richness and diversity of lithic tool forms is rather limited in this small sample size. However, a look at the range of tool forms recovered from Mission San José by a number of previous excavations (e.g., Clark 1978; Hard et al. 1995; Schuetz 1970; Tomka and Fox 1997) indicates a more diverse chipped stone assemblage consisting of "thumbnail scrapers", minimally retouched end and side scrapers, a variety of edge-modified flakes (use worn but not retouched), spokeshaves, gravers, perforators, indeterminate bifaces, arrow points, and gun flints. This range more accurately reflects the relative diversity of lithic tool forms that continued to be used by mission Indians and parallels the patterns noted by Hester (1977, 1982, 1989) at the majority of the missions in South Texas.

The tool and debitage assemblages also indicate a deemphasis on the manufacture of bifacial tool classes such as large knives. These patterns are in general agreement with patterns noted in many other parts of the country during the Late Prehistoric and ProtoHistoric periods (Parry and Kelly 1987; Sullivan and Rosen 1985). This shift from primarily bifacial reductions strategies to more expedient core technologies is attributed to decreased mobility (Parry and Kelly 1987:285). In addition, this assemblage composition pattern also may reflect the use, availability, and long use-life of metal knives and a relative lack of raw materials for the manufacture of metal arrow points. 


\section{Vertebrate Faunal Remains}

\section{Barbara A. Meissner}

\section{Methods}

A total of 18,893 vertebrate faunal remains, weighing $22,847.51 \mathrm{~g}$, was recovered during the project. In the field, all but two units were dug with shovels, and the bone was recovered by screening the sediment through 1/4-inch mesh. Units 2 and 4 were hand dug in natural levels, in order to observe the nature of the bone deposit in situ. Bones were bagged with other artifacts by unit and level. In the laboratory all bone was washed, dried, then bagged by unit and level. The bone was identified to the lowest possible taxon using the comparative collection at CAR, as well as several standard reference texts (Balkwill and Cumbaa 1992; Boessneck 1970; Gilbert 1990; Hildebrand 1955; Hillson 1986; Olsen 1960,1964, 1968; Schmid 1972). Identifications were conservative, i.e. bone which appeared to be cow-sized was not identified as Bos taurus unless it could be differentiated from Bison and Equus species. All bone was weighed. Evidence of exposure to heat was noted on all bone. Element, portion of element, side, evidence of immaturity, and kind of breakage were noted on bone identified to the order taxonomic level. The degree of weathering, and whether or not bones had been gnawed was noted whenever possible. A list of identified taxa is given in Table 17, with counts and weights. When bone could be identified only to class (e.g. mammal, bird, etc.) an estimate of the size of the animal was made when possible.

\section{Analysis}

This collection is even more highly fragmented than other collections from recent excavations at San José (Hard et al. 1995; Hunziker 1998; Meissner 1998). More than 87 percent of the bone could be identified only as mammalian. Only 449 bones (2.4 percent) could be identified to the genus taxonomic level. Thirty-three taxa were identified to at least the genus level in the collection.
Attempts to estimate the relative abundance of various taxa in a faunal collection are usually based on either the Number of Identified Specimens (NISP) or Minimum Number of Individuals (MND). Each method has methodological problems (see Grayson 1984). NISP does not take into consideration such factors as the degree of fragmentation of bone, and whether bone of one taxa comes from one or many different animals. MNI, which indicates the smallest number of individuals of a taxa needed to account for the elements recovered, is calculated by dividing the identified paired elements into right and left sides. The most numerous element indicates the MNI. Grayson (1984:34-39) indicates that MNI is subject to considerable variation, depending on how the collection is aggregated by the analyst (i.e., by the site as a whole, by excavation units, by levels, etc.). In this collection, MNI calculations were only made on the two catchment basins where two sets of six contiguous units were excavated. Since most of these units were dug in arbitrary levels, fauna from all levels of each catchment area were grouped together. The results are listed in Table 18. Only 5 of 25 taxa listed in Table 18 have an MNI greater than 1. While this provides an estimate of how many animals are represented, their relative importance is masked by the low sample numbers, a common problem when using MNI in highly fragmented collections (Grayson 1984:29-49; Hard et al. 1995:86; Meissner 1998). In these situations, NISP is probably a better indicator of relative abundance.

Table 19 lists NISP of bone identified to the genus taxonomic level. Cattle dominate the identifiable assemblage, constituting 37.5 percent of the total NISP. Other commonly eaten domestic mammals, including goats, sheep and pigs were 13.8 percent, while wild animals often hunted for food, including bison, deer, rabbit, raccoon and opossum were 18.7 percent of the total. Birds commonly used as food, i.e. geese and chickens, were 2.2 percent of the total, and fish 2.7 percent. Turtle remains were 14.7 percent of the total NISP.

Bone weight is, in general, a better indicator of relative dietary importance (as opposed to relative abundance) than NISP, but this measure must be used with some caution. In general, larger bones carry more meat, but 
Table 17. Identified Taxa

\begin{tabular}{|c|c|c|c|}
\hline Taxa & Common Name & Count & Weight $(\mathrm{g})$ \\
\hline Mammalia & \multicolumn{3}{|l|}{ Mammals } \\
\hline Artiodactyl & Deer, she ep, goats & 57 & 136.91 \\
\hline Bison bison & American bison & 12 & 278.69 \\
\hline Bos taurus & Cattle & 168 & 3503.34 \\
\hline Bovinae & Cattle or bison & 476 & 3525.82 \\
\hline Canis sp. & Dog, wolf, or coyote & 3 & 2.45 \\
\hline Capra hircus & Domestic goat & 4 & 6.83 \\
\hline Capra /Ovis & Goat or sheep & 3 & 6.74 \\
\hline Carnivora & Carnivore & 1 & 0.34 \\
\hline Didelphis virginianus & Opossum & 6 & 6.64 \\
\hline Equus sp. & Horses & 1 & 5.25 \\
\hline Geomys sp. & Pocket gophers & 1 & 0.08 \\
\hline Mephitis mephitis & Striped skunk & 1 & 0.22 \\
\hline Neotoma cf. albigula & White-throated woodrat & 7 & 2.46 \\
\hline Neotoma sp. & Woodrats & 5 & 1.20 \\
\hline Odocoileus virginianus & White-tailed deer & 28 & 246.08 \\
\hline Ovis aries & Domestic sheep & 15 & 81.90 \\
\hline Procyon loto: & Raccoon & 1 & 0.26 \\
\hline Rattus rattus & Black rat & 2 & 0.28 \\
\hline Rodentia & Rodents & 24 & 3.64 \\
\hline Sciurus sp. & Tree squirrels & 2 & 1.12 \\
\hline Sigmodon his sidus & Cotton rat & 4 & 0.99 \\
\hline Sus scrofa & Domestic pig & 43 & 195.85 \\
\hline Sylvilagus sp. & Cottontail rabbit & 37 & 13.40 \\
\hline Mammal-ve y small & mouse, rat-sized & 2 & 0.15 \\
\hline Mammal-sn all & Rabbit-sized & 17 & 3.95 \\
\hline Mammal-m :dium & Dog-sized & 20 & 18.42 \\
\hline Mammal-la ge & Deer, sheep-sized & 54 & 124.34 \\
\hline Mammal-vey large & Cattle, bison, horse-sized & 1043 & 5534.10 \\
\hline Mammal & Size indeterminate & 16506 & 8863.12 \\
\hline \multicolumn{2}{|r|}{ Total Mammals } & 18543 & 22564.57 \\
\hline Aves & \multicolumn{3}{|l|}{ Birds } \\
\hline Anser sp. & Geese & 2 & 12.09 \\
\hline Branta sp. & Snow geese & 1 & 1.95 \\
\hline Buteo sp. & Hawks & 3 & 3.12 \\
\hline Columbidae & Doves, pigeons & 1 & 0.06 \\
\hline Gallus domesticus & Chicken & 7 & 2.66 \\
\hline Aves-small & Sparrow-sized & 13 & 2.48 \\
\hline Aves-medium & Pigeon-sized & 35 & 8.53 \\
\hline Aves-large & Chicken-sized & 51 & 30.41 \\
\hline Aves-very large & Turkey, hawk-sized & 12 & 17.83 \\
\hline & Total Birds & 125 & 79.13 \\
\hline
\end{tabular}


Table 17. continued

\begin{tabular}{|c|c|c|c|}
\hline Taxa & Common Name & Count & W eight (g) \\
\hline Reptilia & Reptiles & & \\
\hline Alligator mississippiensis & Alligator & 3 & 7.47 \\
\hline Chelydra serpentina & Snapping turtle & 4 & 13.89 \\
\hline Chrysemys sp. & & 1 & 3.44 \\
\hline Colubridae & Non-poisonous snakes & 2 & 0.37 \\
\hline Crotalus atrox & West. diamondback rattlesnake & 7 & 3.77 \\
\hline Lampropeltis sp. & King snakes & 3 & 0.68 \\
\hline Pitophis sp. & Bull snakes & 4 & 0.89 \\
\hline Pseudomys sp. & Pond sliders & 36 & 42.74 \\
\hline Serpentes & Snakes & 1 & 0.17 \\
\hline Terrepene sp. & Box turtles & 5 & 5.67 \\
\hline Testudinata & Turtles & 86 & 58.57 \\
\hline Thamnophis sp. & Garter snakes & 1 & 0.24 \\
\hline Trionyx sp. & Softshelled turtles & 16 & 30.16 \\
\hline Trionyx spineferous & Spiny softshelled turtles & 4 & 9.91 \\
\hline & Total Reptil es & 173 & 177.97 \\
\hline Osteichthys & \multicolumn{3}{|l|}{ Boney Fishes } \\
\hline Ictalurus sp. & Catfish & 11 & 3.35 \\
\hline Pylodictus olivaris & Bullhead catfish & 1 & 0.55 \\
\hline Osteichthyes & Unidentified fish & 21 & 6.07 \\
\hline \multicolumn{2}{|r|}{ Total Fishes } & 33 & 9.97 \\
\hline \multirow[t]{2}{*}{ Vertebrata } & Unidentified bone & 19 & 15.87 \\
\hline & O verall Totals & 18893 & 22847.51 \\
\hline
\end{tabular}

Table 18. MNI by Groups of Units

\begin{tabular}{|c|c|c|c|}
\hline \multirow{2}{*}{ Genus } & \multicolumn{2}{|c|}{ MNI } & \multirow{2}{*}{ Total } \\
\hline & Units 1-6 & Units 7-12 & \\
\hline \multicolumn{4}{|c|}{ Mammalia } \\
\hline Bison & 1 & & 1 \\
\hline Bos & 4 & 1 & 5 \\
\hline Canis & 1 & & 1 \\
\hline Capra & 1 & 1 & 2 \\
\hline Didelphis & 1 & 2 & 3 \\
\hline Mephitis & & 1 & 1 \\
\hline Neotoma & 2 & 2 & 4 \\
\hline Odocoileus & 1 & 1 & 2 \\
\hline Ovis & 1 & 1 & 2 \\
\hline Procyon & & 1 & 1 \\
\hline Rattus & & 1 & 1 \\
\hline Sigmodon & 2 & & 2 \\
\hline Sus & 2 & 1 & 3 \\
\hline Sylvilagus & 1 & 2 & 3 \\
\hline
\end{tabular}

\begin{tabular}{|c|c|c|c|}
\hline \multirow{2}{*}{ Genus } & \multicolumn{2}{|c|}{ MNI } & \multirow{2}{*}{ Total } \\
\hline & Units 1-6 & Units 7-12 & \\
\hline \multicolumn{4}{|c|}{ Aves } \\
\hline Anser & & 1 & 1 \\
\hline Buteo & 2 & & 2 \\
\hline Gallus & 1 & 1 & 2 \\
\hline \multicolumn{4}{|c|}{ Reptilia } \\
\hline Alligator & & 1 & 1 \\
\hline Chelydra & 1 & & 1 \\
\hline Chrysemys & 1 & & 1 \\
\hline Crotalus & 1 & & 1 \\
\hline Lampropeltis & & 1 & 1 \\
\hline Pseudomys & 1 & 1 & 2 \\
\hline Trionyx & & 1 & 1 \\
\hline \multicolumn{4}{|c|}{ Osteichthyes } \\
\hline Ictalurus & 1 & 1 & 2 \\
\hline Total & 25 & 21 & 46 \\
\hline
\end{tabular}


Table 19. Bone Identified to the Genus Taxonomic Level, with NISP, Counts, and Percentages

\begin{tabular}{|c|c|c|c|c|}
\hline Genus & Count & $\%$ & W eight (g) & $\%$ \\
\hline \multicolumn{5}{|c|}{ Mammalia } \\
\hline Bison & 12 & 2.67 & 278.69 & 6.21 \\
\hline Bos & 168 & 37.42 & 3503.34 & 78.03 \\
\hline Canis & 3 & 0.67 & 2.45 & 0.05 \\
\hline Capra & 4 & 0.89 & 6.83 & 0.15 \\
\hline Didelphis & 6 & 1.34 & 6.64 & 0.15 \\
\hline Equus & 1 & 0.22 & 5.25 & 0.12 \\
\hline Geomys & 1 & 0.22 & 0.08 & 0.00 \\
\hline Mephitis & 1 & 0.22 & 0.22 & 0.00 \\
\hline Neotoma & 12 & 2.67 & 3.66 & 0.08 \\
\hline Odocoileus & 28 & 6.24 & 246.08 & 5.48 \\
\hline Ovis & 15 & 3.34 & 81.90 & 1.82 \\
\hline Procyon & 1 & 0.22 & 0.26 & 0.01 \\
\hline Rattus & 2 & 0.45 & 0.28 & 0.01 \\
\hline Sciurus & 2 & 0.45 & 1.12 & 0.02 \\
\hline Sigmodon & 4 & 0.89 & 0.99 & 0.02 \\
\hline Sus & 43 & 9.58 & 195.85 & 4.36 \\
\hline Sylvilagus & 37 & 8.24 & 13.40 & 0.30 \\
\hline Total Mammals & 340 & 75.72 & 4347.04 & 96.82 \\
\hline \multicolumn{5}{|c|}{ Aves } \\
\hline Anser & 2 & 0.45 & 12.09 & 0.27 \\
\hline Branta & 1 & 0.22 & 1.95 & 0.04 \\
\hline Buteo & 3 & 0.67 & 3.12 & 0.07 \\
\hline Gallus & 7 & 1.56 & 2.66 & 0.06 \\
\hline Total Birds & 13 & 2.90 & 19.82 & 0.44 \\
\hline \multicolumn{5}{|c|}{ Reptilia } \\
\hline Alligator & 3 & 0.67 & 7.47 & 0.17 \\
\hline Chelydra & 4 & 0.89 & 13.89 & 0.31 \\
\hline Chrysemys & 1 & 0.22 & 3.44 & 0.08 \\
\hline Crotalus & 7 & 1.56 & 3.77 & 0.08 \\
\hline Lampropeltis & 3 & 0.67 & 0.68 & 0.02 \\
\hline Pitophis & 4 & 0.89 & 0.89 & 0.02 \\
\hline Pseudomys & 36 & 8.02 & 42.74 & 0.95 \\
\hline Terrepene & 5 & 1.11 & 5.67 & 0.13 \\
\hline Thamnophis & 1 & 0.22 & 0.24 & 0.01 \\
\hline Trionyx & 20 & 4.45 & 40.07 & 0.89 \\
\hline Total Reptiles & 84 & 18.71 & 118.86 & 2.65 \\
\hline \multicolumn{5}{|c|}{ Osteichthyes } \\
\hline Ictalurus & 11 & 2.45 & 3.35 & 0.07 \\
\hline Pylodictus & 1 & 0.22 & 0.55 & 0.01 \\
\hline Total Fish & 12 & 2.67 & 3.90 & 0.09 \\
\hline Overall Totals & 449 & 100.00 & 4489.62 & 100.00 \\
\hline
\end{tabular}


the relationship is not linear, varies among different taxa, and there is considerable variation from one part of the animal to another (e.g. lower legs of cattle are dense, heavy bones but carry relatively little meat compared to other bones of the body) (Lyman 1994:389). Table 20 shows the percentage of total NISP weight for each of the categories listed in the paragraph above.

Evidence of exposure to heat can indicate whether bone was routinely thrown into the fire as a disposal method. Only 4.3 percent $(n=820)$ of the bone from this collection showed evidence of heat alteration. Of these, 39.4 percent $(n=323)$ were calcined or partially calcined, while 60.6 percent $(n=497)$ were smoke stained or charred. The relatively high percentage of the burned bone that is heavily heat-altered is evidence that at least some of the bone was being deliberately burned, probably as a disposal method. However, the very small numbers of burned bone indicate that this was not the primary method of bone disposal.

Evidence of gnawing by animals was very rare in this collection. Only three bones showed evidence of tooth marks. Two of these had carnivore tooth marks, including canid-sized and much smaller (cat or skunk-
Table 20. Percent of Total NISP Bone Weight for Selected Taxa

\begin{tabular}{|l|c|}
\hline \multicolumn{1}{|c|}{ Taxon } & $\begin{array}{c}\text { \% of Total } \\
\text { NISP Weight }\end{array}$ \\
\hline Bos taurus & 78.03 \\
\hline Goats, sheep, pigs & 6.34 \\
\hline Wild mammals hunted for food & 12.14 \\
\hline Birds used for food & 0.37 \\
\hline Fish & 0.09 \\
\hline Turtles & 2.36 \\
\hline
\end{tabular}

sized). One bone, a first phalange of a cow, showed evidence of extensive gnawing by rodents. The bone looks as if a small rodent gnawed a hole into the bone, and continued gnawing, hollowing the bone, before chewing a pair of exit holes on the other end (Figure 23). Rarity of both rodent and carnivore gnawing indicates that either a high percentage of the bone was rendered unappealing to rats and dogs (presumably by boiling), or that the bone was buried immediately after disposal, or both.

Weathering data, however, suggests that most of the bone spent at least some time exposed to atmospheric

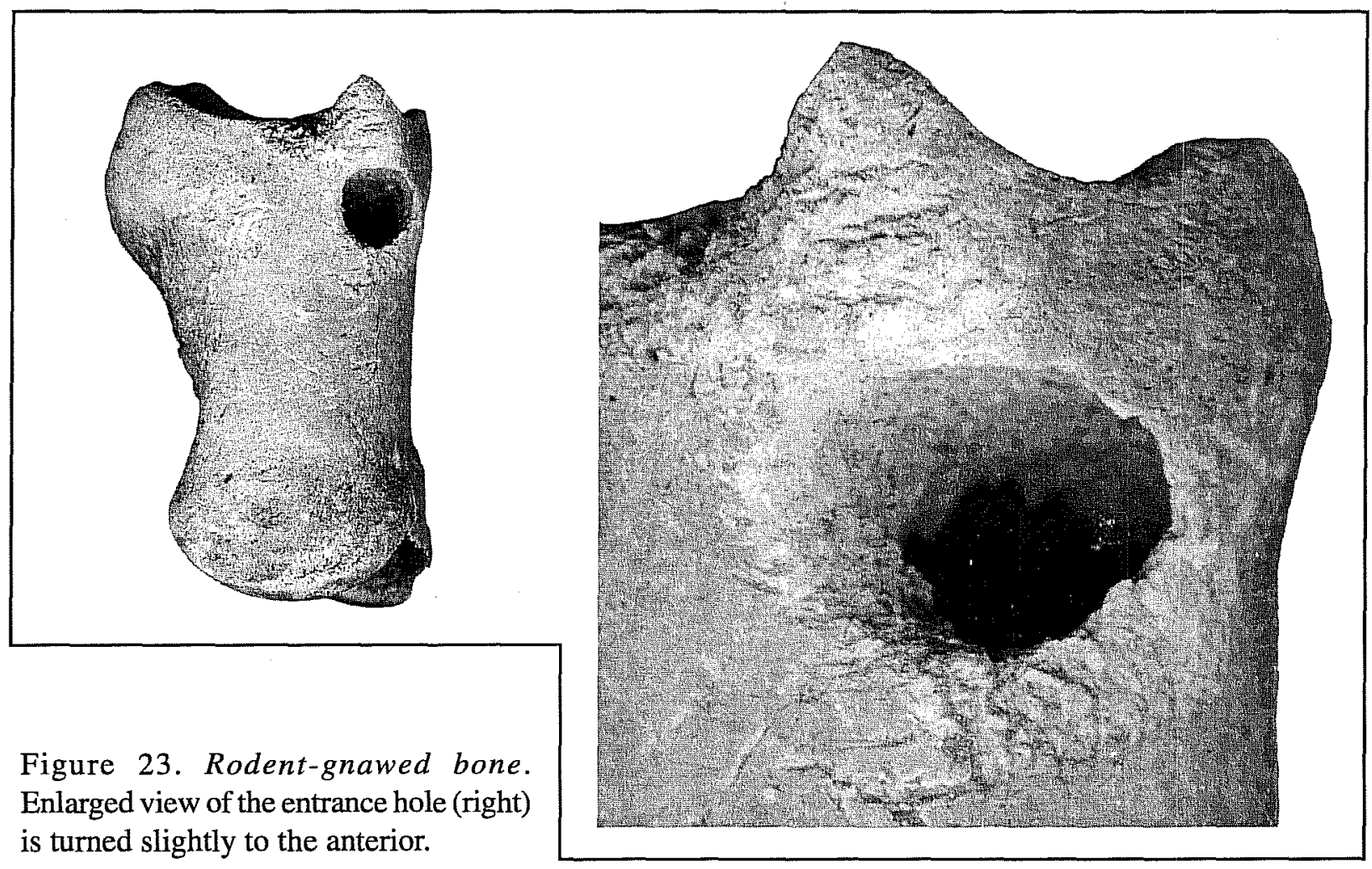


weathering. Only 30.4 percent $(n=5,742)$ of the bone was large enough to observe weathering damage. Of these, 70.3 percent $(n=4307)$ showed evidence of the early stages of weathering, i.e., fine longitudinal cracking and roughing of the surface texture, while 13.2 percent $(n=760)$ showed evidence of more extensive weathering, with longitudinal cracking both more numerous and deeper, and the beginnings of surface exfoliation. Only 11.8 percent $(n=675)$ of the bone large enough to make the observation appeared to have no exposure to atmospheric weathering. The very low incidence of gnawing, both rodent and carnivore, and the high percentage of bone that shows at least some exposure to atmospheric weathering suggests that the bone was left on the surface only in a condition which made it unappealing to scavengers, either because it had been boiled, or because it had once been buried long enough to lose most of its organic component. The variability of weathering on bone even within a unit/level suggests that at least some of the bone was secondary deposit in that area.

Although this collection is too fragmented to allow useful examination of butchering practices, evidence of butchering and other tool marks were identified. Table 21 lists the type of mark and the number of bones on which the mark was observed. Only seven bones (two of which could be conjoined) were found with machine saw cuts, and only six (two of which conjoined) were found with hand saw cuts. About 48 percent $(n=44)$ of the bone which showed butcher marks had been chopped. One bone, a first phalange of a cow, showed extensive thin cut marks near the proximal end (Figure 24). Eight bones (7.3 percent) showed evidence of impact fractures, indicating that the bone had been deliberately broken open with a blunt object, presumably a hammerstone.

\section{Discussion}

The bone in this collection could not, of course, be assigned with certainty to any particular time period in the 200 years during which the mission served as a residential area. Hard et al. (1995:71-80) have shown that animal bone in the San José compound is strongly correlated with Colonial period ceramics but not with post-Colonial ceramics, suggesting that most of the bone in the mission compound is Colonial in origin.

Figure 24. Bone with numerous cut marks, posterior view.

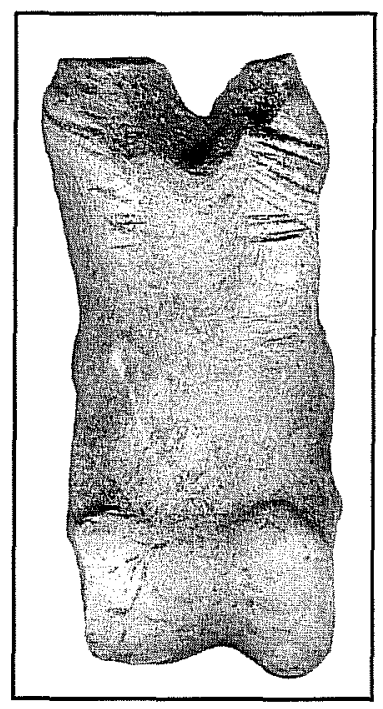

Table 21. Butcher Marks Observed on Bone

\begin{tabular}{|l|l|c|}
\hline \multicolumn{1}{|c|}{ Type } & \multicolumn{1}{|c|}{ Description } & Count \\
\hline Thin cut mark & Thin superficial cut, most likely from knife. & 7 \\
\hline Thick cut mark & $\begin{array}{l}\text { Thicker superficial, from heavy knife or small } \\
\text { hatchet. }\end{array}$ & 3 \\
\hline Chop mark & $\begin{array}{l}\text { Heavy deep cut which may or may not have } \\
\text { completely severed bone. }\end{array}$ & 44 \\
\hline Hand saw cut & \multicolumn{1}{|c|}{ Total } & 91 \\
\hline Machine saw cut & $\begin{array}{l}\text { Bone is saw cut, but method used cannot be } \\
\text { determined. }\end{array}$ & 8 \\
\hline Saw cut-indeterminate & \multicolumn{1}{|c|}{9} \\
\hline Impact scar & \multicolumn{1}{|c|}{} & 6 \\
\hline
\end{tabular}


The presence of bison in this assemblage also suggests the Colonial period, as this species was hunted out of the area around San Antonio by about the 1830 s (Weniger 1997:13). The rarity of saw marks, especially machine saw marks is another piece of evidence suggesting that the majority of the bone in this collection was butchered before the midnineteenth century, however, the highly fragmented condition of this collection and the small number of bone which showed any kind of butchering marks (see Table 21) detracts from the force of this observation. Most of the sediments excavated during this project contained artifacts from the Colonial period to the twentieth century, indicating there has been considerable disturbance along the south wall. However, in both catchment areas intact Colonialperiod deposits were recovered. Animal bone was recovered in very large amounts in these areas. The evidence suggests that the majority of the bone in this assemblage is probably Colınial in origin.

The highly fragmented condition of bone in this collection is common but "tot universal in colonial period sites. Table 22 shows sone counts, weights and NISP of bone from several recent excavations: the current project, three recent excavations at San José (Hard et al. 1995; Hunziker 998; Meissner 1998), an excavation at Mission S an Antonio de Valero (Meissner 1996), and at the S Janish Governor's Palace
(Meissner 1997). The faunal analyses in several earlier publications were examined, but the practice of including bone weight in published reports was not established until recently.

Table 20 clearly shows that average bone weight tends to be about .8 grams, if the anomalous data from Hunziker (1998) is excluded. Hunziker (1998:26) noted that the bone she examined was much larger and less fragmented than was commonly seen in mission projects in San Antonio, and suggested that most of the bone from that project was located in an area out of normal foot traffic patterns.

There are several possible causes for the highly fragmented nature of the collection. Cultural practices such as shattering of long bones to extract marrow and boiling bone to extract bone grease are probably contributing factors. Although time constraints prevented an analysis of all broken long bones, long bones from Very Large (cow-sized) Mammals from a few unit/levels, chosen arbitrarily to represent various parts of the excavation and various depths, were examined in more detail. The unit/levels chosen were: Level 1 of Units 3,13,14,16,17, and 19; Level 2 of Units 1, 2, 4, 7, 9, 10, and 24; and Level 3 of Units 2, 3,6 , and 7 . This constitutes roughly 18 percent of the total number of unit/levels. Table 23 shows break types of long bones of Very Large Mammals in these units

Table 22. Comparison of Bone Counts, Weights, and NISP in Six Recent Colonial Site Excavations

\begin{tabular}{|c|c|c|c|c|c|c|}
\hline & 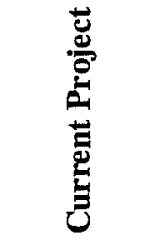 & 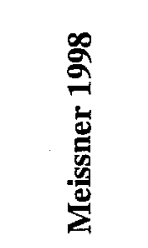 & 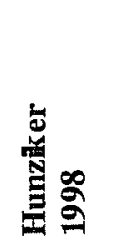 & 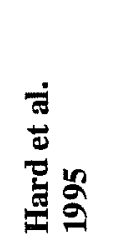 & 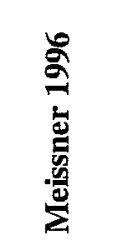 & 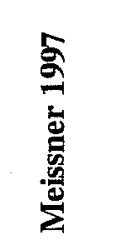 \\
\hline Count & 18,883 & 10,900 & 1709 & 5038 & 1255 & 1952 \\
\hline Weight (g) & $22,847.51$ & $10,205.20$ & 5390.87 & $*$ & 1195.44 & 1463.65 \\
\hline NISP & 449 & 379 & 206 & 161 & 343 & 184 \\
\hline$\%$ NISP & 2.4 & 3.5 & 12.1 & 3.2 & 27.3 & 9.4 \\
\hline $\begin{array}{l}\text { Avg. bone } \\
\text { wt. (g) }\end{array}$ & 0.83 & 0.94 & 3.15 & .53 & .95 & .75 \\
\hline
\end{tabular}

*Total bone weight was not listed, but average bone weight was. 
Table 23. Break Types on Long Bones of Cow-sized Mammals

\begin{tabular}{|c|l|r|}
\hline Category & \multicolumn{1}{|c|}{ Description } & \multicolumn{1}{c|}{ Count } \\
\hline 1 & broken while fresh & 57 \\
\hline 2 & broken while dry & 18 \\
\hline \multicolumn{2}{|r|}{ Types 1 \& 2 both present } & 39 \\
\hline & Total & $\mathbf{1 1 4}$ \\
\hline
\end{tabular}

as well as long bone from all bovinae. Fifty percent of these bone had Type 1 breaks. Only 15.8 percent showed Type 2 .

The extraction of bone grease involves breaking bone, especially the ends of long bones, which have a high fat content, into small pieces and then boiling of the bone for an extended period. The shattering of the bone ends leaves them much less identifiable. The boiling removes organic content and probably makes the bone more friable after burial. The very low numbers of identifiable long bone ends of bovids $(n=17)$, the numbers of Very Large Mammal bone ( $n=1043)$, and the very high numbers of bone too fragmented to identify animal size $(n=16,506)$ suggest that large parts of this bone are the result of boiling to extract bone grease. Not all of the bone appears to have been processes in this way however. The presence of large numbers of phalanges of cow and bison and the large percent of long bone fragments which show only Type 1 breaks indicate that some bone was either broken to extract marrow only and then discarded, or thrown away without boiling.

Trampling of bone probably also contributed to fragmentation (Schiffer 1987:126-127). San José has been in continuous use since it was founded on this location. Foot and vehicle traffic may have caused a great deal of the breakage. This excavation has shown that much of the upper levels along the South wall have been disturbed, which would also cause fragmentation. The excavations themselves, especially since they were carried out during a very rainy season, contributed to the bone fragmentation, since bone is much more friable when it is wet, and tends to fragment when it dries unevenly.

\section{Conclusion}

The degree of fragmentation of bone from this project, so common to colonial sites (Table 22), makes assessment of the assemblage somewhat problematic. Cattle dominate the identifiable assemblage, with bison and deer and a few smaller wild mammals the next most abundant. Small domestic artiodactyls such as goats, sheep and pigs are present in small numbers. Only a few birds and fish bones were identified. Turtles were fairly common, but provide only a small part of the total weight.

The bones represent a meat diet consisting mostly of beef augmented by hunted animals, sheep, pigs and goats. Only a few bones each of the remaining identified taxa were present. The pattern is similar to that seen in faunal assemblages from recent excavations at San José, with the exception that bison and deer constituted a larger percentage of this assemblage than was seen in any recent excavation. 


\section{Stratigraphic and Spatial Structure of the Deposits}

\section{Steve A. Tomka}

The archaeological excavations carried out by CAR personnel focused on areas immediately adjacent the base of the reconstructed mission wall (the western and central catch basins) and areas located some $12-21 \mathrm{ft}$ from the wall (connecting and main drainage pipe trenches). In addition, while 25 of the 27 units were excavated in arbitrary six-inch levels, two were dug following natural stratigraphy. This section discusses three issues: 1) the stratigraphic and chronological relationship of the different excavation levels; 2) the vertical position of the dense bone deposit; and 3) the structure of the archaeological remains within the excavated areas.

The comparison of the relative proportions of artifact types by level offers a reasonable estimate of the nature and stratigraphic integrity of the deposits in the two catch basins and along the drainage pipe trenches. Tables 24-27 present the distributions of ceramic types by excavation levels within the areas investigated.
Within the units excavated by arbitrary levels, in both the western (Table 24) and central (Table 25) catch basins, Level 1 (0-12 inches bs) contains the lowest percentages of colonial (unglazed) and the highest percentage of post-colonial (other wares, whitewares, tin-glazed, and lead-glazed) ceramics. Colonial wares constitute between 50-75 percent of the specimens in Level 1 in the two catch basins. As depth below surface increases with each level, the percentage of colonial wares also increases. In Level 3, for example, between 96-99 percent of the ceramics are unglazed Goliad wares. The vertical distribution of ceramic follows this same trend in the two units (Unit 2 and 4) excavated employing natural stratigraphy (Table 26). In these units, Level 1 (0-12 inches bs) contained the caliche layer that predates the CWA reconstruction of the mission walls. Only 61 percent of the ceramics recovered from this level are colonial wares. On the other hand, Level 2 (12-18 inches bs) contained 94 percent colonial wares, and the two deeper levels contain exclusively colonial ceramics. For the purposes of this discussion, Levels 2 (12-14 inches) and 3 (14-15.5 inches) from Unit 4 were combined since they represent deposits overlying the dense bone layer present throughout the excavation areas.

Table 24. Distribution of Ceramic Types by Arbitrary Level Within the Western Catch Basin, Units $1,3,5$, and 6

\begin{tabular}{|c|c|c|c|c|c|c|c|c|c|c|c|}
\hline \multirow{2}{*}{ Level } & \multicolumn{2}{|c|}{ Unglazed } & \multicolumn{2}{|c|}{ Other Wares } & \multicolumn{2}{|c|}{ Whitewares } & \multicolumn{2}{|c|}{ Tin-Glazed } & \multicolumn{2}{|c|}{ Lead-Glazed } & \multirow{2}{*}{ Total } \\
\hline & \# & $\%$ & $\#$ & $\%$ & $\#$ & $\%$ & \# & $\%$ & $\#$ & $\%$ & \\
\hline 1 & 61 & 50 & 7 & 6 & 41 & 34 & 5 & 4 & 7 & 6 & 121 \\
\hline 2 & 108 & 89 & 2 & 2 & 5 & 4 & 5 & 4 & 1 & 1 & 121 \\
\hline 3 & 85 & 96 & 0 & 0 & 2 & 2 & 1 & 1 & 1 & 1 & 89 \\
\hline 4 & 4 & 100 & 0 & 0 & 0 & $\underline{0}$ & 0 & 0 & 0 & 0 & 4 \\
\hline Total & 258 & & 9 & & 48 & & 11 & & 9 & & 335 \\
\hline
\end{tabular}

Table 25. Distribution of Ceramic Types by Level Within the Central Catch Basin

\begin{tabular}{|c|c|c|c|c|c|c|c|c|c|c|c|}
\hline \multirow{2}{*}{ Level } & \multicolumn{2}{|c|}{ Unglazed } & \multicolumn{2}{|c|}{ Other Wares } & \multicolumn{2}{|c|}{ Whitewares } & \multicolumn{2}{|c|}{ Tin-Glazed } & \multicolumn{2}{|c|}{ Lead-Glazed } & \multirow{2}{*}{ Total } \\
\hline & $\#$ & $\%$ & $\#$ & $\%$ & $\#$ & $\%$ & \# & $\%$ & \# & $\%$ & \\
\hline 1 & 88 & 75 & 1 & 1 & 21 & 18 & 4 & 3 & 4 & 3 & 118 \\
\hline 2 & 320 & 97 & 2 & 1 & 1 & 0 & 1 & 0 & 6 & 2 & 330 \\
\hline 3 & 392 & 99 & 0 & 0 & 0 & 0 & 0 & 0 & 2 & 1 & 394 \\
\hline 4 & 1 & 50 & 0 & 0 & $\underline{0}$ & 0 & 0 & 0 & 1 & 50 & $\underline{2}$ \\
\hline Total & 801 & & 3 & & 22 & & 5 & & 13 & & 844 \\
\hline
\end{tabular}


Table 26. Distribution of Ceramic Types by Natural Level Within the Western Catch Basin, Units 2 and 4

\begin{tabular}{|c|c|c|c|c|c|c|c|c|c|c|c|}
\hline \multirow{2}{*}{ Level } & \multicolumn{2}{|c|}{ Unglazed } & \multicolumn{2}{|c|}{ Other Wares } & \multicolumn{2}{|c|}{ Whitewares } & \multicolumn{2}{|c|}{ Tin-Glazed } & \multicolumn{2}{|c|}{ Lead-Glazed } & \multirow{2}{*}{ Total } \\
\hline & \# & $\%$ & $\#$ & $\%$ & $\#$ & $\%$ & $\#$ & $\%$ & $\#$ & $\%$ & \\
\hline 1 & 27 & 61 & 2 & $\underline{5}$ & 14 & 32 & 0 & 0 & 1 & 2 & 44 \\
\hline 2 & 61 & 94 & 2 & 3 & 1 & 2 & 1 & $\underline{2}$ & 0 & 0 & 65 \\
\hline 3 & 280 & 100 & 0 & $\underline{0}$ & 0 & $\underline{0}$ & 0 & 0 & 0 & 0 & 280 \\
\hline 4 & 37 & 100 & 0 & $\underline{0}$ & 0 & 0 & 0 & $\underline{0}$ & 0 & 0 & 37 \\
\hline Total & 405 & & 4 & & 15 & & 1 & & 1 & & 426 \\
\hline
\end{tabular}

Level 1=0-12 inches bd; Level 2=12-16 inches bd; Level 3=16-20 inches bd; Level 4=20-27 inches bd

Table 27. Distribution of Ceramic Types by Natural Level Within the Connecting and Main Pipe Trenches, Units 13-27

\begin{tabular}{|c|c|c|c|c|c|c|c|c|c|c|c|}
\hline \multirow{2}{*}{ Level } & \multicolumn{2}{|c|}{ Unglazed } & \multicolumn{2}{|c|}{ Other Wares } & \multicolumn{2}{|c|}{ Whitewares } & \multicolumn{2}{|c|}{ Tin-Glazed } & \multicolumn{2}{|c|}{ Lead-Glazed } & \multirow{2}{*}{ Total } \\
\hline & \# & $\%$ & $\#$ & $\%$ & $\#$ & $\%$ & $\#$ & $\%$ & $\#$ & $\%$ & \\
\hline 1 & 236 & 45 & 56 & 11 & 184 & 35 & 11 & 2 & 39 & 7 & 526 \\
\hline 2 & 80 & 60 & 23 & 17 & 23 & 17 & 2 & 1 & 6 & 4 & 134 \\
\hline 3 & 9 & 60 & 3 & 20 & 2 & 13 & 0 & 0 & 1 & 7 & 15 \\
\hline 4 & 0 & 0 & 0 & $\underline{0}$ & 1 & 100 & 0 & 0 & 0 & 1 & 1 \\
\hline Total & 325 & & 82 & & 210 & & 13 & & 46 & & 676 \\
\hline
\end{tabular}

This distributional pattern supports the observation that while the caliche layer does not cap purely colonial deposits it was laid down relatively early in the occupation sequence that produced the majority of the early twentieth century whitewares present in Level 1 throughout the mission grounds. A historic photograph (see Hard et al. 1995:Figure 7) dated ca. 1920, shows the area in the general vicinity of the central and western catch basins. Visible between buildings aligned along the outer mission wall are bright areas that appear to be gravel-packed driveways. It is highly probable that the caliche layer noted in the western catch basin represents a caliche-lined driveway from around the same period.

The distribution of ceramic types by level within the units located away from the base of the mission wall is significantly different (Table 27). Colonial ceramics only constitute 45 percent of the specimens in Level 1 and even in the deeper levels they do not increase over 60 percent. This ceramic distribution pattern suggests that the activities that are responsible for the large number of colonial ceramics found along the wall base did not extend very far south of the wall. And, conversely, the post-colonial, and in particular latenineteenth and early-twentieth century, occupations tended to use a larger area resulting in broader refuse distribution patterns.

This conclusion has to be evaluated with caution since the long profiles connecting the catchment basin units with the trench units (see Figures 3, 6, and 9) indicate that there is a 6-8 inch drop in the elevation of the surface between the base of the wall and the units located along the main drainage pipe trench some $18-21 \mathrm{ft}$ from the wall. It was mentioned earlier that the cultural zone is significantly thinner at this distance from the wall. It is possible that the top soil laid down to create some of this change in grade was scraped up and pushed against the wall from $20-30 \mathrm{ft}$ or further. Judging from the profile in Figure 6, it is also likely that some grade adjustments also were accomplished by repositioning even some material-bearing deposits. For instance, the caliche layer in Units 2, 4, and 6 is found encased within the cultural zone. Furthermore, the gray-brown cultural zone is missing for the most part from Unit 16 , beginning as a thin wedge immediately to its north. This pattern suggests that 
the cultural zone was scrapped up from $15 \mathrm{ft}$ or further from the wall and laid over the caliche layer and sprinkler pipe trench. The top soil may have been laid on top to provide additional increase in grade.

Although these are likely reconstructions of modern impacts in the area impacted by the present project, they do not rule out the probability that colonial deposits simply did not extend very far from the wall of the mission. After all, the redeposition of the upper few inches of the cultural zone against the base of the wall should have left the deeper deposits containing primarily colonial period materials in place. However, even the deposits that remained contained relatively high proportions of post-colonial wares, even at a depth of 12-24 inches bs (Table 27). Overall, then, these ceramic distribution patterns do support the original interpretation that as one moves $15-21 \mathrm{ft}$ from the base of the wall the colonial period materials become sparser and more mixed with post-colonial remains.

An additional artifact type which is associated primarily with the colonial period occupation of the mission and occurs in large quantities is the faunal remains. As a result, identification of the level or levels with the highest bone densities can aid in isolating the depositional units most likely to contain high proportions or unmixed colonial materials. Table 28 presents the distribution of faunal remains by arbitrary and natural level within the two catch basins and along the drainage pipe trenches. It is evident that within the two catch basins, the highest bone densities occur in Levels 2 (12-18 inches) and Level 3 (18-24 inches) below surface. In the two units excavated following natural stratigraphy, the highest bone density occurred in Level 3 and 4 (15-20 inches and 20-26 inches bs, respectively). The excavations revealed that the highest densities of bone are found immediately above and on the contact between the cultural zone and the Houston Black clay. High numbers of faunal remains also are found in the top mottled portion of the clay.

In most units located close to the base of the south wall, this contact zone is found about 18-20 inches bs. As a result, in the two catch basins and in the immediate vicinity of the east gate, the bone layer appears to extend from 16-20 inches below surface. Unfortunately, this four-inch layer tends to be divided between two arbitrary levels. So that, the upper portion of the bone layer is in the bottom of Level 2 (12-18 inches bs) and top of Level 3 (18-24 inches bs). It is this bone distribution patterns that causes high numbers of faunal remains to be excavated from Levels 2 and 3 of units dug in arbitrary levels. Figure 24 illustrates this relationships between the arbitrary and natural strata and the bone layer in Units 2, 4, and 1.

The horizontal distribution of faunal remains offers additional evidence of the thinning of the colonial deposits with increasing distance from the mission wall. In excavating the 12 units associated with the two catch basins approximately 357,696 cubic inches of deposits were removed. These deposits yielded a total of about 12,535 pieces of faunal remains, or an average of one bone for every 28 cubic inches of matrix. In excavating the 15 units along the connecting and main pipe trenches a total of 337,608 cubic inches of material were removed. The deposits produced a total of about 1,683 bones, or one bone for every 200 cubic inches of deposits, a more than six-fold decrease

Table 28. Vertical Distribution of Faunal Remains Within the Western and

Central Catch Basins and the Pipe Trenches

\begin{tabular}{|c|c|c|c|c|c|c|c|c|}
\hline \multirow{3}{*}{ Level } & \multicolumn{2}{|c|}{ Western Catch Basin } & \multicolumn{2}{|c|}{ Western Catch Basin } & \multicolumn{2}{|c|}{ Cental Catch Basin } & \multicolumn{2}{|c|}{ Pipe Trenches } \\
\hline & \multicolumn{2}{|c|}{ Arbitrary Levels } & \multicolumn{2}{|c|}{ Natural Levels } & \multicolumn{2}{|c|}{ Arbitrary Levels } & \multicolumn{2}{|c|}{ Natural Levels } \\
\hline & \# & $\%$ & \# & $\%$ & \# & $\%$ & $\#$ & $\%$ \\
\hline 1 & 739 & 19 & 187 & 5 & 511 & 10 & 1683 & 68 \\
\hline 2 & 1916 & 49 & 399 & 11 & 3106 & 60 & 797 & 32 \\
\hline 3 & 1189 & 31 & 1655 & 47 & 1532 & 30 & 13 & 1 \\
\hline 4 & 43 & 1 & 1178 & 34 & 8 & 0 & & $\underline{0}$ \\
\hline 5 & & 0 & 72 & 2 & & 0 & & $\underline{0}$ \\
\hline Total & 3887 & 100 & 3491 & 100 & 5157 & 100 & 2493 & 100 \\
\hline
\end{tabular}




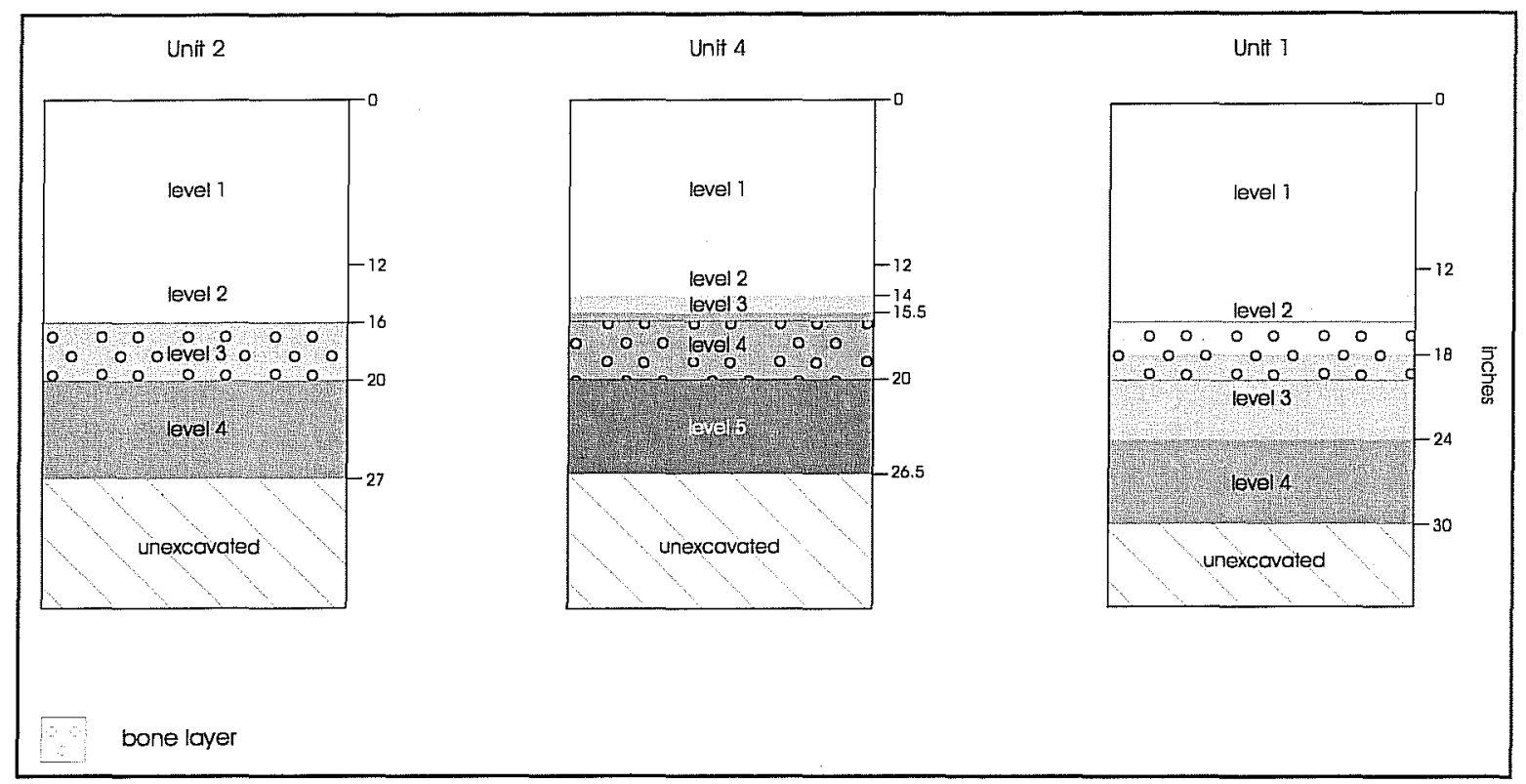

Figure 24. The relationship between arbitrary and natural strata and bone layer, Units 2, 4, and 1 .

in bone density compared to units found within nine feet of the wall.

Interestingly, the colonial period unglazed ceramics exhibit a similar spatial distribution. The catchment basin excavations yielded about 1,464 unglazed specimens, or one sherd for every 244 cubic inches of deposit. On the other hand, the pipe trench units produced 325 colonial sherds, or one sherd for every 1,039 cubic inches of matrix. Even more importantly, the post-colonial ceramics have the opposite distribution. The catch basin excavations produced 141 post-colonial sherds, or an average of 1 sherd for every 2,537 cubic inches of deposits. The excavations associated with the pipe trenches yielded 351 postcolonial ceramics, or an average of one sherd for every 962 cubic inches of matrix.

Taken together, the horizontal distribution of faunal remains, colonial and post-colonial ceramics all indicate significant differences in the use of the space adjacent and south of the mission wall. The colonial materials appear to concentrate relatively near the base of the wall and decrease in density as one moves more than nine feet from the wall. The post-colonial materials tend to be most numerous at a distance of between 15-21 ft from the wall. The concentrated nature of the colonial materials appears to indicate the presence of dumps. In contrast, the more dispersed character of the post-colonial ceramics suggests a sheet midden-type deposit.

The colonial refuse distribution pattern is intriguing especially since high densities of bone were found along the entire length of the 102-ft section of the wall where the present and last fall's excavations took place (Tomka and Fox 1998). The presence of a continuous deposit of faunal remains extending some 100 feet from the southeast gate suggests that it does not represent the remains of a gate-associated midden. Relatively high densities of bones were encountered in all units excavated along the base of the west, east, and south walls of the mission (see Tomka and Fox 1998). Such a bone distribution pattern suggests either that the deposits predate the construction of a continuous perimeter wall and Indian Quarters, or that activities were regularly carried out on the roofs of the Indian Quarters, including the dumping of refuse outside of the mission walls.

Regular variations in bone densities along the east/ west running trench associated with the connecting and main drainage pipes supports the pre-wall hypothesis. Figure 25 shows the distribution of total bone densities in all 27 units excavated in association with the construction of the catchment basins. While the number of faunal remains is consistently high in the 12 units of the two catch basins, there is a regular 
alteration of high and low count units along the pipe trench. With the exception of Units 21 and 22, each of which has high bone counts, every other unit with bone counts above 300 has a lower bone count unit in its vicinity. This distribution of high density clusters surrounded by low density areas is reminiscent of individual refuse dumps associated perhaps with individual households or residential units. It is unknown at this point whether the bone distribution adjacent the wall base has a similar pattern or represents a continuous high density deposit.

\section{Summary and Recommendations}

Archaeological excavations were conducted by CAR personnel at Mission San José y San Miguel de Aguayo in February and early March 1998. These excavations had three goals: 1) identify any architectural features that may have originally been outside of the mission walls; 2) better define the stratigraphy of the cultural materials in the area; and 3 ) recover intact colonial period materials that might otherwise be lost.

The excavations revealed no architectural features in the area impacted by the construction of three catchment basins and associated drainage pipes. Two historic period features have been identified: Feature 1, a discarded brazier, and Feature 2, two intersecting hearths. The brazier was encountered in Level 2 of Unit 5 in the western catch basin. The two intersecting hearths were found in Units 10 and 28 of the central catch basin. They were dug from Level 1 (ca. 11-12 inches bs) to a depth of about 23 inches bs. Given the quantity and types of historic remains found within the hearths, it is likely that they date to the early 1900 s, possibly between 1903 and 1920 .

Although no architectural features have been encountered the results have some bearing on the general use of the mission. Specifically, the large quantity of faunal remains encountered along the base of the reconstruction wall, and the continuous nature of the deposits suggests that the midden-like deposits are not associated with a gate midden. Rather, they suggest that the deposits might predate the construction of the mission walls. Further exploratory excavations should be conducted along other portions of the mission wall to identify the presence or absence of similar deposits.

Finally, the analyses of the vertical distributions of faunal remains and colonial and pre-colonial ceramics indicate that the bone layer is found between a depth of $16-20$ inches bs in the vicinity of the wall base. It is distributed immediately above and below the contact between the gray-brown cultural zone and the Houston Black clay substratum of the site. Using arbitrary excavation levels, the bone layer tends to be encountered in the bottom portion of Level 3 (12-18 inches bs) and the upper portion of Level 4 (18-24 inches bs). It is these same levels that contain pristine or nearly pristine colonial age deposits.

The spatial structure of the colonial and post-colonial deposits indicate some significant differences in the use of space adjacent the wall base in the two time periods. The colonial deposits tend to concentrate within nine feet of the wall base while the post-colonial materials are most common beyond $12-15 \mathrm{ft}$ from the wall. This distributional pattern may result in part from post-depositional disturbances to the deposits (e.g., grade improvements). However, it is also likely that it results from differences in the use of space by native groups residing within the mission versus later groups residing along the outer walls of the mission following the collapse of the mission walls.

Overall, based on the results of these excavations, it is concluded that subsurface disturbances associated with the construction of the three catch basins will not impact significant colonial deposits since all of these deposits have been removed during the archaeological excavations. The subsurface disturbances associated with the construction of the connecting and main drainage pipes will impact only severely mixed deposits that consist of a thin veneer of colonial materials mixed with a predominantly postColonial late-nineteenth- and early-twentieth-century materials. Therefore, it is recommended that the planned excavations associated with the construction of the three catchment basins proceed as planned without the need for further archaeological investigations in the area to be impacted. 


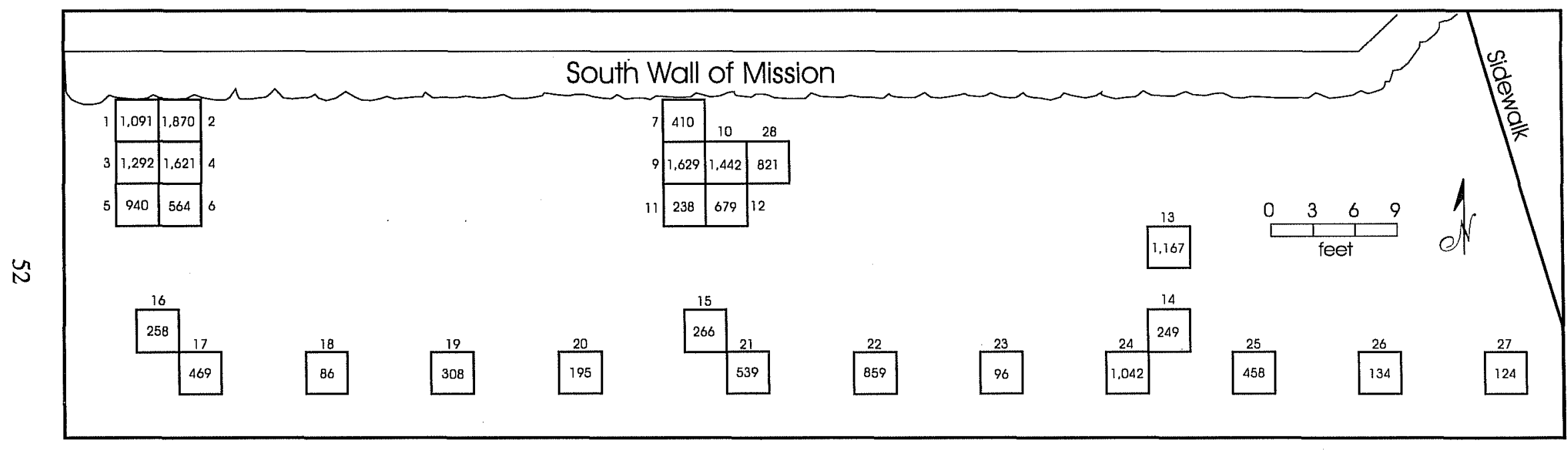

Figure 25. Distribution of total bone densities across the project area. 


\section{References Cited}

Balkwill, D. M., and S. L. Cumbaa

1992 A Guide to the Identification of Postcranial Bones of Bos taurus and Bison bison. Canadian Museum of Nature, Ottawa.

Barnes, M. R.

1980 Mexican Lead-Glazed Earthenwares. In Spanish Colonial Frontier Research, compiled and edited by H. F. Dobyns, pp. 92-110. Spanish Borderlands Research, No. 1. Center for Anthropological Studies, Albuquerque.

Barnes, M. R. and R. V. May

1972 Mexican Majolica in Northern New Spain. Pacific Coast Archaeological Society Occasional Paper, Number 2. Costa Mesa, California.

Boessneck, J.

1970 Osteological Differences Between Sheep (Ovis aries Linné) and Goats (Capra hircus Linné). In Science in Archaeology, edited by D. Brothwell and E. Higgs, pp. 331-358. Praeger, New York.

Charlton, T. H. and R. R. Katz

1979 Tonalá Bruñida Ware, Past and Present. Archaeology 32(1):45-53.

Clark, J. W., Jr.

1978 Mission San José y San Miguel de Aguayo: Archeological Investigations, December 1974. Archeological Report 29. Texas Historical Commission, Austin.

Clark, J. W., Jr., and A. M. Juarez

1986 Urban Archeology: A Culture History of a Mexican-American Barrio in Laredo, Webb County, Texas. Vol.1. Publications in Archeology, Report 31. Texas State Department of Highways and Public Transportation, Highway Design Division, Austin.

Clark, J. W., Jr., and E. J. Prewitt

1979 Archeological Test Excavations in Areas to be Affected by a Proposed French Drain West of the Granary, Mission San José State Historic Site (41BX3), Bexar County, Texas. Reports of Investigations 3. Prewitt and Associates, Austin.

Folan, W. J., I. W. Cox, A. A. Fox, and G. M. Hinojosa

1986 Laredo, Texas: A Gateway Community on the Texas Borderlands. Archaeological and Historical Investigations for the Laredo City Toll Plaza (41WB36, 37, and 38). Archaeological Survey Report, No. 116. Center for Archaeological Research, The University of Texas at San Antonio.

Fox, A. A.

1974 Lead Glazed Wares. In Mission Rosario Archeological Investigations 1973, edited by K. Gilmore, 1:55-60. Archeological Report 14. Texas Parks and Wildlife Department, Historic Sites and Restoration Branch, Austin.

1998 Stoneware Potteries in the San Antonio Area. Presentation at "From the Land -19th Century Texas Stoneware Seminar." National Wildflower Research Center, Austin. 
Fox, A. A. and I. W. Cox

1991 Testing of the San José Mission Acequia, San Antonio Missions National Historical Park, Bexar County, Texas. Archaeological Survey Report, No. 207. Center for Archaeological Research, The University of Texas at San Antonio.

Fox, A. A., F.A. Bass, Jr., and T. R. Hester

1976 The Archaeology and History of Alamo Plaza. Archaeological Survey Report, No. 16. Center for Archaeological Research, The University of Texas at San Antonio.

Fox, D. E.

1970 Archeological Salvage at Mission San José, December 1969 and August 1970. Archeological Report 3. Texas Historical Survey Committee, Austin.

1979 The Lithic Artifacts of Indians at the Spanish Colonial Missions, San Antonio, Texas. Special Report, No. 8. Center for Archaeological Research, University of Texas at San Antonio.

Gerald, R. E.

1968 Spanish Presidios of the Late Eighteenth Century in Northern New Spain. Museum of New Mexico Research Records No. 7, Museum of New Mexico Press, Santa Fe.

Gilbert, B. M.

1990 Mammalian Osteology. Missouri Archaeological Society, Columbia, Missouri.

Goggin, J. M.

1964 The Spanish Olive Jar. In Indian and Spanish Selected Writings. University of Miami Press, Coral Gables, Florida.

Grayson, D. K.

1984 Quantitative Zooarchaeology. Academic, London.

Habig, M. A.

1968a The Alamo Chain of Missions. A History of San Antonio's Five Old Missions. Franciscan Herald, Chicago.

1968b San Antonio's Mission San José. State and National Site 1720-1968. Naylor, San Antonio.

Habig, M. A., compiler

1978 The San José Papers: The Primary Sources for the History of San José y San Miguel de Aguayo from its Founding in 1720 to the Present. Part I:1719-1791. Translated by B. Leutenegger et al. Old Spanish Missions Historical Research Library at Mission San José, San Antonio.

Hard, R. J., A. A. Fox, I. W. Cox, K. J. Gross, B. A. Meissner, G. I. Méndez, C. L. Tennis, and J. E. Zapata 1995 Excavations at Mission San José y San Miguel de Aguayo, San Antonio, Texas. Archaeological Survey Report, No. 218. Center for Archaeological Research, The University of Texas at San Antonio.

Henderson, J. and J. W. Clark, Jr.

1984 Test Excavations at the Acequia and Other Features at Mission San José, Bexar County, Texas. Publications in Archaeology Report 25. State Department of Highways and Public Transportation, Highway Design Division, Austin. 
Hester, T. R.

1977 The Lithic Technology of Mission Indians in Texas and Northeastern Mexico. Lithic Technology 6(1-2):9-13.

1982 Prehistoric Continuities: Mission Indian Chipped Stone Tools. In Historic and Cultural Landscape Survey for the San Antonio Missions, pp. 205-210. Environmental and Cultural Services, San Antonio.

1989 Perspectives on the Material Culture of the Mission Indians of the Texas-Northeastern Mexico Borderlands. In Columbian Conseequences, Vol. 1, edited by D. H. Thomas, pp. 213-229. Smithsonian Institution Press, Washington, D.C.

Hildebrand, M.

1955 Skeletal Differences Between Deer, Sheep, and Goats. California Fish and Game 41:327-346.

Hillson, S.

1986 Teeth. Cambridge University Press, Cambridge.

Hunziker, J. M.

1998 Faunal Analysis. In Investigations of the Southeast Gateway at Mission San José, Bexar County, Texas, by C. L. Tennis, pp.22-26. Archaeological Survey Report No. 252. Center for Archaeological Research, The University of Texas at San Antonio.

Leuttenegger, Fr. B., Fr. M. A., Habig, and M. C. Casso

1978 The San José Papers. Part I: 1719-1791. Old Spanish Missions Historical Research Library, Mission San José, San Antonio.

Lister F. C. and R. H. Lister

1974 Maiolica in Colonial Spanish America. Historical Archaeology 8:17-52.

Lyman, R. L.

1994 Vertebrate Taphonomy. Cambridge University Press, Cambridge.

Meissner, B. A.

1996 The Alamo Restoration and Conservation Project: Excavations at the South Transept. Archaeological Survey Report, No. 245. Center for Archaeological Research, The University of Texas at San Antonio.

1997 Analysis of Vertebrate Faunal Remains. In Test Excavations at the Spanish Governor's Palace, San Antonio, Texas, by A. A. Fox, pp. 21-28. Archaeological Survey Report, No. 259. Center for Archaeological Research, The University of Texas at San Antonio.

1998 Vertebrate Faunal Remains. In Mission San José Indian Quarters Foundation Project, by S. A. Tomka and A. A. Fox. Arcaheological Survey Report, No. 278. Center for Archaeological Research, The University of Texas at San Antonio. In preparation.

Olsen, S. J.

1960 Post-Cranial Skeletal Characters of Bison and Bos. Peabody Museum, Cambridge.

1964 Mammal Remains from Archaeological Sites Part I; Southeastern and Southwestern United States. Peabody Museum, Cambridge.

1968 Fish, Amphibian, and Reptile Remains from Archaeological Sites Part I: Southeastern and Southwestern United States. Peabody Museum, Cambridge. 
Parry, W. J., and R. L. Kelly

1987 Expedient Core Technology and Sedenstism. In The Organization of Core Technology, edited by J. K. Johnson and C. A. Morrow, pp. 285-304. Special Studies in Archaeological Research, Westview, Boulder, Colorado.

Roberson, W., and T. W. Medlin

1976 San José Mission State Historic Site, Archeological Testing 1974 and 1976. Compiled and edited by J. D. Ing. Archeological Report 23. Texas Parks and Wildlife Department, Historic Sites and Restoration Branch, Austin.

Roycroft, D., and C. Roycroft

1975 American Country Pottery. Wallace-Homestead, Des Moines, Iowa.

Schiffer, M. B.

1987 Formation Processes of the Archaeological Record. University of New Mexico Press, Albuquerque.

Schmid, E.

1972 Atlas of Animal Bones for Prehistorians, Archaeologists, and Quaternary Geologists. Elsevier, Amsterdam.

Schuetz, M. K.

1968 The History and Archeology of Mission San Juan Capistrano, San Antonio, Texas. Vol. I. Report 10. State Building Commission Archeological Program, Austin.

1969 The History and Archeology of Mission San Juan Capistrano, San Antonio, Texas. Vol. I. Report 11. State Building Commission Archeological Program, Austin.

1970 Excavation of a Section of the Acequia Madre in Bexar County, Texas, and Archeological Investigations at Mission San José in April 1968. Archeological Report 19. Texas Historical Survey Committee, Austin.

Sullivan, A. P., and K. C. Rosen

1985 Debitage Analysis and Archaeological Interpretation. American Antiquity 50:755-779.

Tennis, C. L.

1998 Investigations of the Southeast Gateway at Mission San José, Bexar County, Texas. Archaeological Survey Report, No. 252. Center for Archaeological Research, The University of Texas at San Antonio.

Tomka, S. A.

1989 Differentiating Lithic Reduction Techniques: An Experimental Approach. In Experiments in Lithic Technology, edited by Daniel S. Amick and Raymond P. Mauldin, pp. 137-161. BAR International Series 528 .

Tomka, S.A., and A. A. Fox

1998 Mission San José Indian Quarters Foundation Project, Bexar County, Texas. Archaeological Survey Report, No. 278. Center for Archaeological Research, The University of Texas, San Antonio.

Turner, E. S., and T. R. Hester

1993 A Field Guide to Stone Artifacts of Texas Indians. Second Edition. Gulf, Houston. 
Weniger, D.

1997 The Explorers' Texas. Vol. 2: The Animals They Found. Eakin, Austin.

Zapata, J.

1997 Alamodome and Abroad: A Composite Inquiry on Toy Marbles. In Archaeology at the Alamodome: Investigations of a San Antonio Neighborhood in Transition. Volume III: Artifact and Special Studies, edited by A. A. Fox, M. Renner, and R. J. Hard, pp. 100-118. Archaeological Survey Report, No. 238. Center for Archaeological Research, The University of Texas at San Antonio. 
